\title{
Amended Ballistic Sand Studies to Provide Low Maintenance Lead Containment at Active Small Arms Firing Range Systems
}

Steven L. Larson, Phil G. Malone, Charles A. Weiss,

W. Andy Martin, Casey Trest, Gene Fabian, Michael F. Warminsky, David Mackie, Jeffrey J. Tasca, Jack Wildey, and Judith Wright

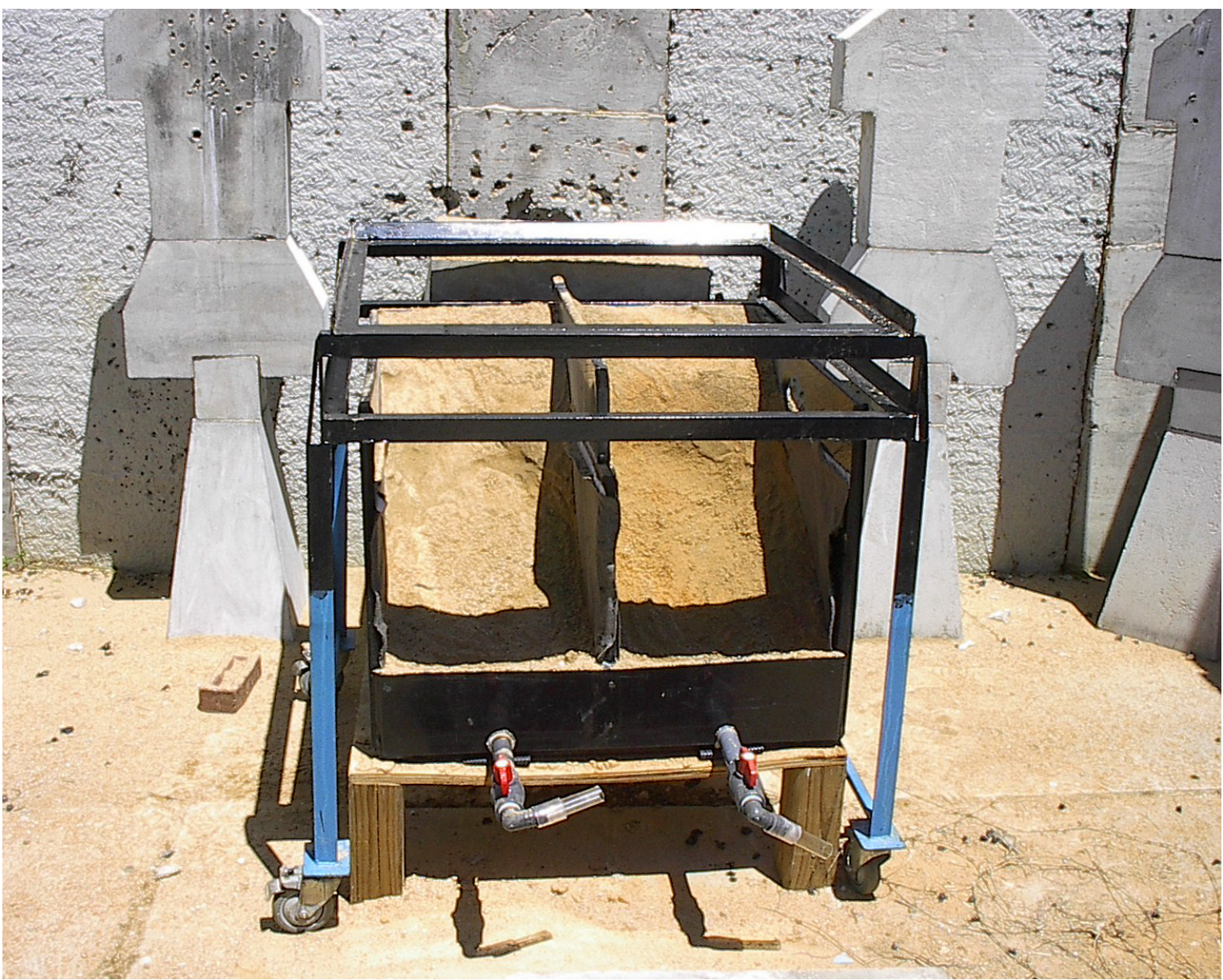




\section{Amended Ballistic Sand Studies to Provide Low Maintenance Lead Containment at Active Small Arms Firing Range Systems}

Steven L. Larson, W. Andy Martin, and Casey Trest

Environmental Laboratory

U.S. Army Engineer Research and Development Center

3909 Halls Ferry Road

Vicksburg, MS 39180-6199

Phil G. Malone and Charles A. Weiss

Geotechnical and Structures Laboratory

U.S. Army Engineer Research and Development Center

3909 Halls Ferry Road

Vicksburg, MS 39180-6199

Gene Fabian

Aberdeen Test Center

4264 Cowan Place

Belcamp, MD 21017

Michael F. Warminsky, David Mackie, and Jeffrey J. Tasca

AMEC Earth and Environment

285 Davidson Avenue, Suite 100

Somerset, NJ 08873

Jack Wildey

EnviroComp, Inc.

3240 Hickory Woods Drive

Greenfield, IN 46140

Judith Wright

UFA Ventures, Inc.

403 West Riverside Drive

Carlsbad, NM 88220

Final report

Approved for public release; distribution is unlimited. 


\begin{abstract}
Live-fire training results in the deposition of heavy metals, such as lead and copper, into berm soils. The metals range in size from whole projectiles to microscopic dust. Surface water runoff and leachate have the potential to transport metals off-site. The Passive Reactive Berm (PRBerm) technology incorporates berm amendments with ballistic sand to immobilize soluble metals (e.g., lead) during the inevitable bullet corrosion process. Treatability studies determined that a sand to amendment ratio of 5 percent $(\mathrm{w} / \mathrm{w})$ was sufficient to contain greater than 90 percent of soluble lead within the berm material. Lysimeter studies used regulated artificial rain events to evaluate the metals concentrations, total suspended solids, dissolved organic carbon, and runoff and leachate $\mathrm{pH}$ over time for the amended and sand-only (control) berms.
\end{abstract}

The Buffer Block \#5 and SulfiTech A/T maintained average leachate lead and copper concentrations below the selected study limit of $0.150 \mathrm{mg} / \mathrm{L}$ and $0.500 \mathrm{mg} / \mathrm{L}$, respectively, maintained a pH between 6 and 9, and maintained a dissolved organic carbon level at less than $50 \mathrm{mg} / \mathrm{L}$ for the leachate and runoff waters. Lysimeter studies indicate that amendment biological activity and $\mathrm{pH}$ affects the use of certain amendments within the PRBerm. The benefits of the PRBerm when compared to the traditional earthen berm, or a fully-contained bullet trap, include reduced metals migration, and reduced construction and operation costs.

DISCLAIMER: The contents of this report are not to be used for advertising, publication, or promotional purposes. Citation of trade names does not constitute an official endorsement or approval of the use of such commercial products. All product names and trademarks cited are the property of their respective owners. The findings of this report are not to be construed as an official Department of the Army position unless so designated by other authorized documents. 


\section{Contents}

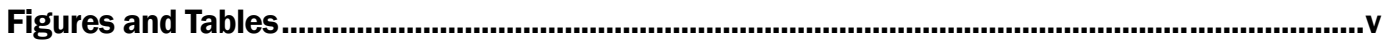

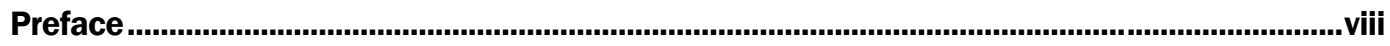

Unit Conversion Factors..........................................................................................................................ix

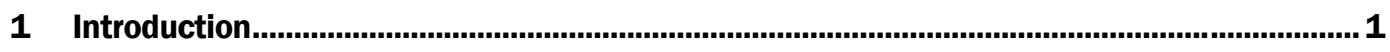

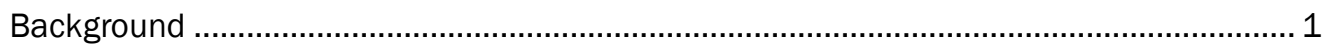

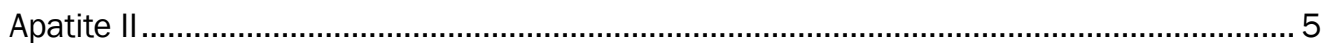

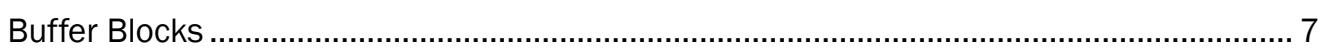

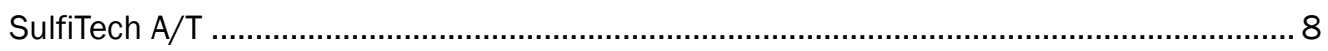

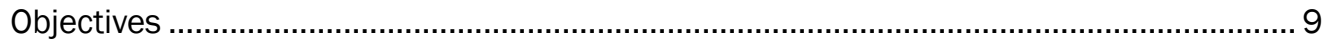

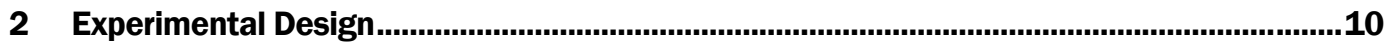

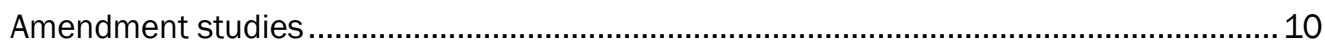

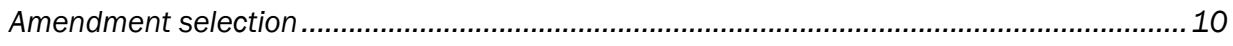

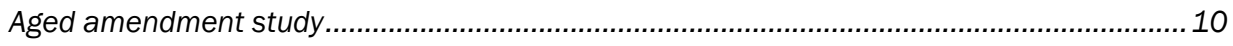

Column study

Lysimeter Studies ............................................................................................... 11

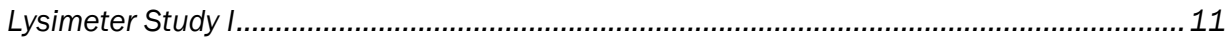

Lysimeter Study II .................................................................................................. 12

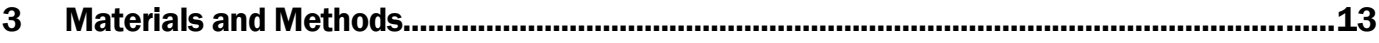

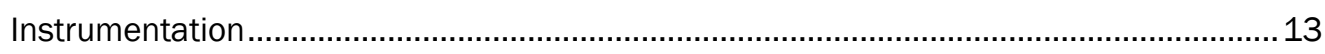

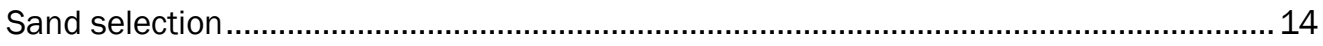

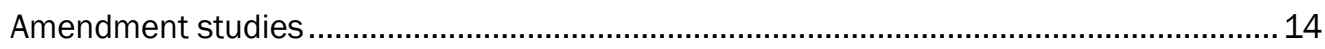

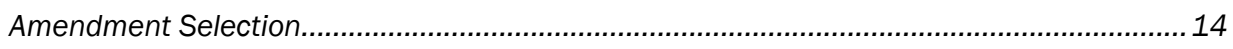

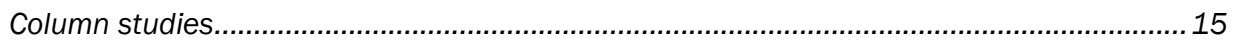

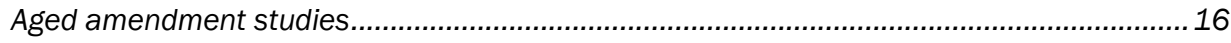

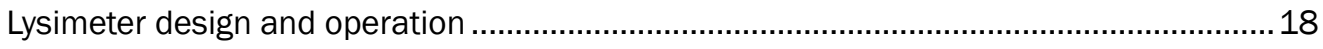

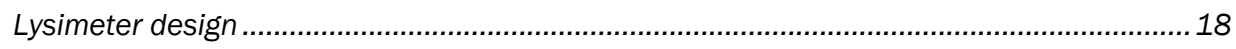

Surface runoff and leachate collection system ....................................................................18

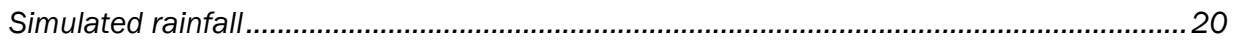

Sand preparation and lysimeter loading procedures........................................................2 20

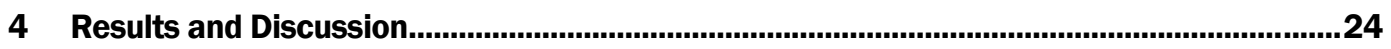

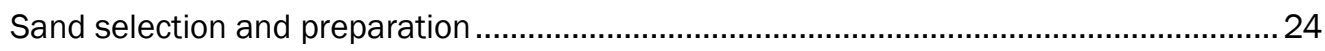

Amendment selection ................................................................................... 27

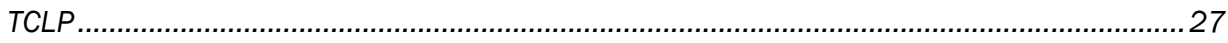

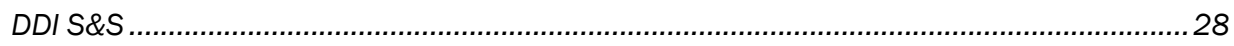

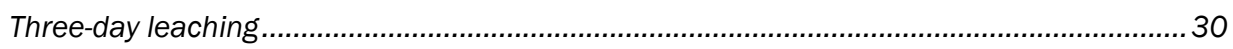

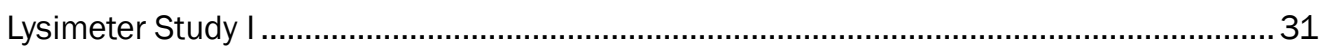

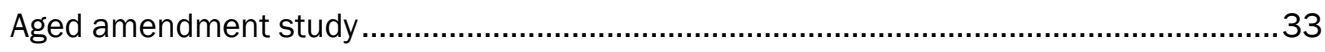




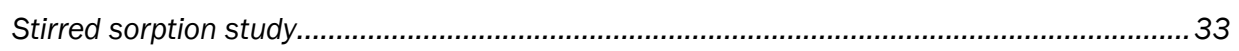

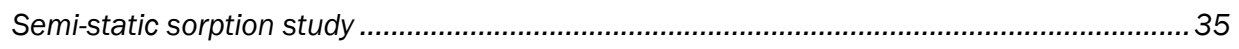

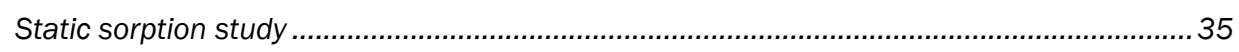

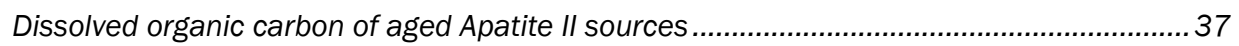

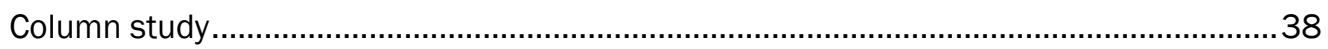

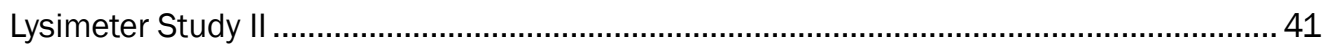

5 Conclusions and Recommendations ............................................................................51

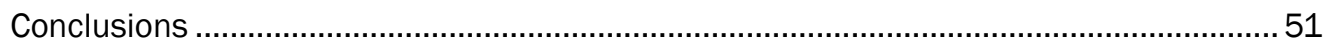

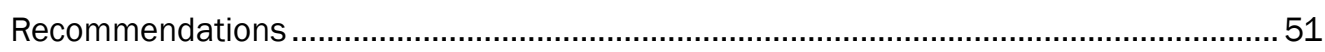

References.....................................................................................................................................53

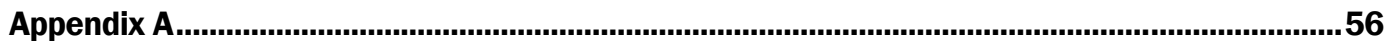

Preliminary sand evaluation data.................................................................................. 56

Amendment selection (TCLP, DDI S\&S, 3-day leaching) ................................................56

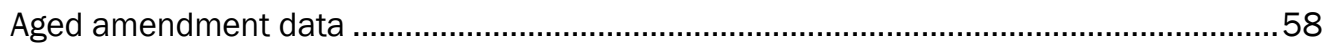

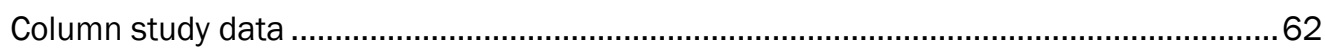

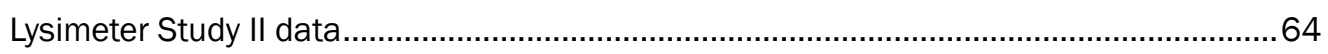

\section{Report Documentation Page}




\section{Figures and Tables}

\section{Figures}

Figure 1. Cross section of lysimeter 18

Figure 2. Empty lysimeter cell showing leachate and runoff collection systems ............................. 19

Figure 3. Lysimeter showing rainfall simulator holding frame and water collection system............. 19

Figure 4. Generation of approximately 9,400 mg lead/ $\mathrm{kg}$ sand ........................................................ 21

Figure 5. Mixing the sand to generate homogeneous bulk samples for use in the lysimeters

Figure 6. Leachate from rain event \#3, notice the dark color associated with the Apatite II (center three-APII) as compared to the control (C) and Buffer Block \#4 (BB\#4) leachates

Figure 7. Comparison of lead concentration of Mechanical and Baked Apatite II from the semi-static sorption studies

Figure 8. Soluble lead concentration in solution after 18-hour static sorption experiments using aged Apatite II

Figure 9. Total (digested liquid) lead concentration in solution after 18 hour static sorption experiments using aged Apatite II material ..

Figure 10. Daily DOC $(<0.45 \mu \mathrm{m})$ from the aging solution of the Apatite II sources..........................38

Figure 11. Soluble lead concentration for the Apatite II amendments in leachate during Phase I of the column study...

Figure 12. Soluble lead concentration in leachate for the Buffer Block \#5 and SulfiTech amendments during Phase I of the column study.....

Figure 13. Total soluble lead leaving the column by phase.

Figure 14. Leachate (left) and TSS filters (right) from rain event \#4.

Figure 15. Enzyme and Mechanical Apatite II DOC and filtered lead concentrations in Lysimeter Study II

Figure 16. TSS and total lead from the 16 rain events for each amended soil and the correlation between TSS and amount of lead leaving the system as runoff and leachate

Figure 17. Sum of soluble lead leaving the columns and lysimeters

\section{Tables}

Table 1. Solubility products of selected lead minerals 9

Table 2. Experimental design for Lysimeter Studies I and II.......................................................... 12

Table 3. Chemical and physical analytical procedures used during the treatability studies .............13

Table 4. Estimated instrument detection limits for compounds of concern..................................... 14

Table 5. Calculated metals concentration based on sand and number of rounds fired....................20

Table 6. Comparison of potential sands for the PRBerm $(n=3)$...................................................... 25

Table 7. Particle size distribution in potential PRBerm sands........................................................ 25

Table 8. Metal concentration in Red River sand pre- and post- lead enrichment.............................26 
Table 9. Results of the TCLP evaluation of amendments in SAFR berm soil ..................................28

Table 10. Results of the DDI S\&S evaluation of amended SAFR soil..............................................29

Table 11. Results of the 3-day leaching evaluation of amended berm soil.......................................30

Table 12. Lysimeter cell leachate ....................................................................................... 32

Table 13. Lysimeter cell runoff........................................................................................... 32

Table 14. Reduction of lead during the stirred sorption study of aged Mechanical Apatite II

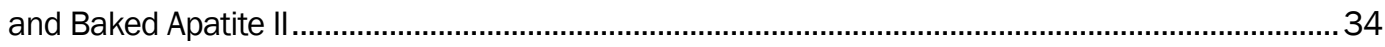

Table 15. Lysimeter Study II pre- and post-amendment berm sand lead TCLP and DDI S\&S

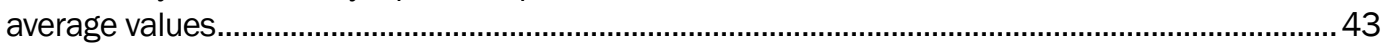

Table 16. Lysimeter Study II pre- and post-amendment berm sand copper TCLP and DDI

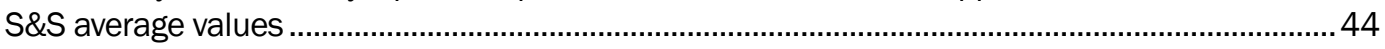

Table 17. Lysimeter cell leachate values for lead, copper, DOC, and pH (16-week average)............ 45

Table 18. Soluble leachate metals from lysimeter cell (16-week average) ........................................ 46

Table 19. Total leachate metals from lysimeter cell (16-week average) .............................................46

Table 20. Lysimeter cell runoff water (16-week average).................................................................... 47

Table 21. Total soluble lead in leachate normalized based on total lead in cell ................................ 49

Table 22. Total digested lead in leachate normalized based on total lead in cell ............................50

Table A-1. Background metals concentrations in digested sands ................................................ 57

Table A-2. Comparison of TLCP leaching from SAFR berm soil1 by amendment .............................57

Table A-3. DDI S\&S leaching evaluation of SAFR berm soil1 by amendment.................................. 58

Table A-4. Three-day leaching evaluation of SAFR berm soil1 by amendment ................................58

Table A-5. Effects of aged Baked Apatite II on removal of lead from solution...................................59

Table A-6. Comparison of Mechanical and aged Baked Apatite II on removal of lead from

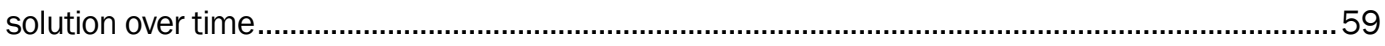

Table A-7. Comparison of Mechanical and aged Baked Apatite II for removal of lead during semi-static sorption studies

Table A-8. Comparison of Mechanical and aged Baked Apatite II on removal of lead during semi-static sorption/settling studies.

Table A-9. Comparison of aged Baked Apatite II material removal of lead from solution during static sorption studies.

Table A-10. Comparison of aged Baked Apatite II material on total lead concentration in solution following static sorption studies.

Table A-11. Column study (saturated and intermittent columns) soluble lead concentrations.

Table A-12. Column study (saturated and intermittent columns) soluble copper concentrations.

Table A-13. Column study soluble lead and copper in leachate from columns using the same columns for each study.

Table A-14. Lysimeter Study II digested lead and copper in leachate and runoff over 16 rain events

Table A-15. Lysimeter Study II soluble lead and copper in leachate and runoff over 16 rain events

Table A-16. Lysimeter Study II average $(n=16)$ soluble metals concentration in runoff....................66

Table A-17. Lysimeter Study II average $(n=16)$ digested metals concentration in runoff. 
Table A-18. Lysimeter Study II amended soil pH for pre- and post-study........................................67

Table A-19. Lysimeter Study II pH values of leachate and runoff water.............................................68

Table A-20. Lysimeter Study II Total Suspended Solids in leachate and runoff ................................69

Table A-21. Lysimeter Study II volume of leachate and runoff water collected..................................70

Table A-22. Lysimeter Study II Dissolved Organic Carbon ( $<0.45$ micron) in runoff and

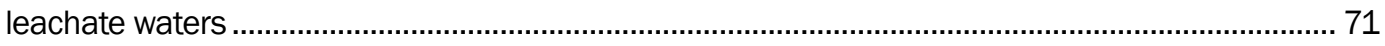




\section{Preface}

The work reported here was conducted at the U.S. Army Engineer Research and Development Center (ERDC), Vicksburg, MS. Funding was provided by the Environmental Security Technology Certification Program (ESTCP). The project was designated as ESTCP project ER-0406.

The work presented in this report was part of an effort to investigate the applicability of amended ballistic sand impact berm material contaminated with metals that are typically found on small arms firing ranges. Dr. Steven L. Larson and W. Andy Martin of the Environmental Engineering Branch (EP-E), Environmental Laboratory (EL), and Drs. Philip Malone and Charles A. Weiss, Jr., Geotechnical and Structures Laboratory (GSL), ERDC, Vicksburg, MS, prepared this report. Assisting were Gene Fabian, Aberdeen Test Center, Aberdeen Proving Ground, MD; Mike Warminsky, David Mackie, and Jeffrey J. Tasca, AMEC Earth and Environment, Somerset, NJ; Jack Wildey, EnviroComp, Inc., Greenville, IN; and Dr. Judith Wright, UFA Ventures, Inc., Carlsbad, NM. We gratefully acknowledge the technical assistance provided by Haley Parsons, ERDC-GSL; Chris Griggs and Michelle Thompson, Applied Research Associates, Inc.; Casey Trest, Mississippi State University; Allison Hearn, University of Southern Mississippi; and Tarmiko Graham and Kerry Taylor, Jackson State University. We also acknowledge the gracious participation of Barbara Legan, Barksdale Air Force Base (AFB), Bossier City, LA, in sharing soil and storm water runoff samples from the Barksdale AFB range complex and for her helpful discussion of the results.

This study was conducted under the direct supervision of Dr. Pat Deliman, Technical Director, Environmental Modeling and Assessments, and Dr. Richard E. Price, Chief, Environmental Processes and Engineering Branch, and under the general supervision of Dr. M. John Cullinane, Technical Director, EL, and Dr. Beth Fleming, Director, EL.

COL Richard B. Jenkins was Commander and Executive Director of ERDC. Dr. James R. Houston was Director. 


\section{Unit Conversion Factors}

\begin{tabular}{|l|l|l|}
\hline Multiply & By & To Obtain \\
\hline inches & 0.0254 & meters \\
\hline miles (U.S. statute) & 1.609347 & kilometers \\
\hline pounds (mass) & 0.45359237 & kilograms \\
\hline
\end{tabular}




\section{Acronyms}

AFB

Air Force Base

ASTM

American Society for Testing and Materials

ATC

Aberdeen Test Center

BMP

Best Management Practice

$\mathrm{Ca}$

Calcium

$\mathrm{Cr}$

Chromium

$\mathrm{Cu}$

Copper

DDI S\&S Distilled Deionized Water Suspend and Settle

DOC Dissolved Organic Carbon

DoD Department of Defense

EL Environmental Laboratory

ERDC Engineer Research and Development Center

ESTCP Environmental Security Technology Certification Program

Fe Iron

GSL Geotechnical and Structures Laboratory

HQDA Headquarters, Department of the Army

HDPE High-density polyethylene

ICP-AES Inductively Coupled Plasma Atomic Emission Spectroscopy

ID Internal diameter

IDL Instrument detection limit

ITRC Interstate Technology and Regulatory Council

LPDES Louisiana Pollution Discharge Elimination System

MCLG Maximum Contamination Level Goal 


\begin{tabular}{|c|c|}
\hline $\mathrm{Mg}$ & Magnesium \\
\hline $\mathrm{Mn}$ & Manganese \\
\hline Mo & Molybdenum \\
\hline $\mathrm{P}$ & Phosphorus \\
\hline $\mathrm{Pb}$ & Lead \\
\hline PR Berm & Passive Reactive Berm \\
\hline PVC & Polyvinyl chloride \\
\hline $\mathrm{R} \& \mathrm{D}$ & Research and development \\
\hline RL & Reporting limit \\
\hline $\mathrm{RO}$ & Reverse osmosis \\
\hline $\mathrm{rpm}$ & Revolutions per minute \\
\hline S & Sulfur \\
\hline $\mathrm{Sb}$ & Antimony \\
\hline SDWA & Safe Drinking Water Act \\
\hline SW & Solid Waste \\
\hline TCLP & Toxicity Characteristic Leachate Procedure \\
\hline TOC & Total Organic Carbon \\
\hline TSS & Total Suspended Solids \\
\hline USEPA & United States Environmental Protection Agency \\
\hline UTS & Universal Treatment Standard \\
\hline $\mathrm{V}$ & Vanadium \\
\hline $\mathrm{w}: \mathrm{v}$ & weight:volume (ratio) \\
\hline $\mathrm{w} / \mathrm{w}$ & weight to weight \\
\hline
\end{tabular}




\section{Introduction}

\section{Background}

Lead $(\mathrm{Pb})$ is considered an environmental threat to health by the federal government. At very low levels, it is linked to subtle developmental delays and reduced mental function in children (USEPA 2001a and 2003). Small arms ammunition is made up largely of metallic lead with smaller amounts of alloying materials such as antimony (a hardening agent) along with copper and zinc, which are the primary components of shell casings and jackets (HQDA 1996; Weiss 2005). The U.S. Environmental Protection Agency (USEPA) estimates that 4 percent of the 2 million tons of all lead produced in the United States in the late 1990s was made into bullets or lead shot (USEPA 2001b). Much of this 160 million pounds of lead finds its way into the environment at firing ranges.

Live-fire training at Small Arms Firing Ranges (SAFRs) is necessary to maintain mission readiness for our Nation's warfighters. The U.S. Department of Defense (DoD) oversees more than 3,000 active SAFRs (ITRC 2003). In addition to these facilities, it is estimated that 9,000 nonmilitary outdoor ranges are now active in the United States as private firing ranges, which are largely unregulated despite the fact that their operations can result in soil, ground water, or surface-water contamination at levels that would trigger major remediation efforts at industrial and/or military sites (Houlihan and Wiles 2002). There have been several Best Management Practices (BMPs) suggested to control lead migration from active SAFRs (Fabian 2005; ITRC 2005; USEPA 2001b), but relatively little research has been done to support the use of these BMPs. Systematic development of SAFR sustainment technologies is necessary to address the feasibility and functionality of such technologies. To demonstrate that a BMP such as the PRBerm will work under field conditions, and at a reasonable cost, extensive batch, pilot, and full-scale research efforts are needed. While significant research and development (R\&D) costs have been associated with the field demonstration and proof-of-concept phases of the PRBerm project, it is anticipated the long-term operational costs associated with the technology will be minimal compared to the R\&D costs.

Long-term use of SAFRs results in lead contamination from spent ammunition deposited within and adjacent to the target berms. Metals occur in 
the form of discrete particles (intact bullets or shot, and fragments), metal salts (weathering products), and dissolved metal or metallic complexes adsorbed to the soil matrix. Typically, more than 96 percent of the lead is present as intact or fragmented bullets or shot (ITRC 2003). Lead bullets striking an impact berm at high speeds may vitrify on impact forming "melts" on individual soil particles. Several investigators have demonstrated that lead ammunition exposed to the elements in surface soil will eventually oxidize to a soluble ionic form (Manninen and Tanskanen 1993; Lin et al. 1995; Murray et al. 1997). This spent ammunition can serve as a concentrated source of lead that could contaminate the environment for many years.

Lead contamination can escape from SAFR sites through weathering effects, storm water runoff, and through leachate (ground water) transport. Small lead particles or "smeared" soil particles may become airborne if wind, foot traffic, or maintenance activities disturb the contaminated soil. Storm water runoff may erode the lead-contaminated berms and carry the lead and contaminated soil particles away from the SAFR into the surrounding environment. Rainfall intensity, ground slope, and soil type strongly influence the potential transport of lead away from the SAFR. Additionally, acid rain, which can have a pH of less than 5, can dissolve lead and transport it to nearby ground or surface waters. The USEPA has established a Maximum Contamination Level Goal (MCLG) for lead in drinking water of $\mathrm{omg} / \mathrm{L}$ and has set the action level as required by the Safe Drinking Water Act (SDWA) at $0.015 \mathrm{mg} / \mathrm{L}$; dissolved lead concentrations above $0.015 \mathrm{mg} / \mathrm{L}$ are considered a potential health concern (USEPA 2002). The threshold toxicity characterization concentration for lead in contaminated soils established by the Toxicity Characteristic Leachate Procedure (TCLP) is $5.0 \mathrm{mg} / \mathrm{L}$ and the universal treatment standard (UTS) for lead is $0.75 \mathrm{mg} / \mathrm{L}$ (ITRC 2003).

Lead is an amphoteric metal that exhibits its greatest solubility in acidic $(\mathrm{pH}<4)$ and alkaline $(\mathrm{pH}>11)$ solutions. Under acidic conditions, elemental lead will oxidize, releasing a hydrated cation, $\mathrm{Pb}^{2+}$. Under alkaline conditions, elemental lead will oxidize under most circumstances to form a lead hydroxide complex $\mathrm{Pb}(\mathrm{OH})_{5^{3-}}$. Lead that exists in the dissolved state can be sorbed to negatively charged clay particle surfaces. Thus, the erosion and surface water transport of contaminated clays can be a major source of lead mobility in the environment, and environmental transport 
can be either attenuated or increased depending upon the mobility of the soil particles.

In the case of Barksdale Air Force Base (AFB), Bossier City, LA, runoff from their SAFR complex exits the property through a storm drain that discharges to a creek bayou that is a tributary of Coopers Bayou. Under Louisiana Pollution Discharge Elimination System (LPDES) permit LAo007293, the maximum total lead limit was established at $0.150 \mathrm{ppm}$ (mg/L), copper was set at $0.500 \mathrm{ppm}$, Total Organic Carbon (TOC) at $50 \mathrm{ppm}$, and $\mathrm{pH}$ between 6 and 9. During periods of heavy rain, this level has been exceeded in the surface water leaving the range. Research performed by the Engineer Research and Development Center Environmental Laboratory (ERDC-EL) in Vicksburg, MS has shown that the majority of the lead contained in the runoff water at Barksdale AFB SAFR complex occurs in the form of insoluble lead adsorbed to suspended colloidal soil particles.

Several factors affect the amount of lead that is dissolved in water. In a typical water body, dissolved lead forms precipitates of lead hydroxide $\left[\mathrm{Pb}(\mathrm{OH})_{2}\right]$, lead carbonate $\left[\mathrm{PbCO}_{3}\right.$, cerrusite], or basic lead carbonate $\left[\mathrm{Pb}_{3}(\mathrm{OH})_{2}\left(\mathrm{CO}_{3}\right)_{2}\right.$, hydrocerrusite $]$. The overall lead solubility in a natural system is fundamentally determined by the concentrations of the anions in solution (e.g., the hydroxide and carbonate ions) and by the ionic strength of the solution, which affects the activity coefficients of the ions. These factors can be related to more directly measured parameters such as $\mathrm{pH}$, alkalinity, and total dissolved solids (TDS) (Vaccari 1992). At pH 7, with an alkalinity of $100 \mathrm{mg} \mathrm{CaCO} 3 / \mathrm{L}$ and TDS of $100 \mathrm{mg} / \mathrm{L}$, the theoretical solubility of lead is $0.242 \mathrm{mg} / \mathrm{L}$. At pH 3.5 under these same conditions, the theoretical solubility of lead is $72.6 \mathrm{mg} / \mathrm{L}$. In any system having water in equilibrium with a solid phase, the metal precipitate that has the lowest solubility will be the only stable solid phase and will increase in its relative concentration at the expense of the more soluble forms. Thus, the presence of lead compounds with extremely low solubilities, such as lead phosphates, influences the solubility and availability of the lead in the environment. Several laboratory and bench-scale remediation studies have demonstrated the effectiveness of the addition of phosphate-based soil amendments in producing highly insoluble lead phosphate minerals such as pyromorphite and hydroxypyromorphite (Berti and Cunningham 1997; Lambert et al. 1997; Ma and Rao 1997; Lower et al. 1998; Traina and Laperche 1999). When sequestered within these phosphate minerals, lead 
has been shown to be far less soluble, as indicated by the results of acid leaching tests (Tardy et al. 2003), and its bioavailability to soil organisms has been demonstrated to be sharply reduced (Berti and Cunningham 1997; Pearson et al. 2000; Traina and Laperche 1999). The USEPA has recognized that bioavailability of lead in contaminated soils varies greatly depending upon its form in the soil, and had suggested that phosphate treatment has potential for in-situ remediation of contaminated soils and sediments (USEPA 2001c).

Compliance with existing state and federal environmental regulations is a major issue in small arms range management. Cost-effective BMPs that will promote good stewardship of the environment while maintaining training-range availability need to be developed. The design and construction of new ranges should consider pollution prevention opportunities (ITRC 2005). One of the critical factors is the choice of material for impact berms. In many cases, local soil characteristics will be adequate to retain lead within the range and maintain surface water or leachate water lead concentrations within applicable regulatory permit limits and/or action levels. In cases where the local soils have undesirable properties for range management purposes, such as high acidity, low $\mathrm{K}_{\mathrm{d}}$ for lead, or easy erosion/transport of soil particles from the berm surfaces; partial replacement of the berm soil with a more suitable ballistic material may provide an economical alternative to steel bullet-trap type systems. Naturally occurring silicate (e.g., quartz, feldspar) mineral sands are relatively lowcost materials that are widely available, due to their extensive use in construction. Impact berms made from sand are able to decelerate fired projectiles safely, with minimal bullet fragmentation and lead-dust generation, as compared to compacted or coarse-grained soils (Larson et al. in press 2006). Sand as a berm material provides a number of advantages:

- The hydraulic conductivity associated with sand reduces surface runoff down the berm face as it tends to form leachate instead.

- Chemical inertness reduces berm material compaction and hardening providing a deceleration media for projectiles.

- Biological inertness reduces the potential for organic, humic, and other related chelating agents that may bind to metals.

- Consistent texture, density, and particle size allows for reduced costs for projectile particulate removal as part of range maintenance or remediation. 
- Low water holding capacity (specific retention) reduces lead/water contact time compared with most soils.

- The refractory nature of silicate sands minimizes the potential fire hazards associated with tracer ammunition.

A number of disadvantages are also associated with the use of sand as a deceleration medium in SAFR berms. Most commercially available silicate sands have a negligible $\mathrm{pH}$ buffering capacity. For this reason, lead within unamended sand berms could be susceptible to dissolution by acid rain. The lack of an adequate natural buffering mechanism could lead to a progressive reduction in berm $\mathrm{pH}$ to levels where both the rate of lead corrosion and extent of lead solubility in water are significantly increased. The low buffering capacity of sand is a result of the relative chemical inertness of common silicate mineral constituents such as quartz. This chemical inertness means that compared with most soils, sand has a lower capacity to reduce the mobility of soluble lead. All of the lead entering a berm on a firing range is initially present as metallic lead in either particulate or bullet form. As the berm system ages, the metallic lead undergoes corrosion processes that result in the release of lead cations. Depending on the environment within the berm, these lead ions can transport to groundwater as soluble lead, transport to surface water as soluble lead, ion exchange onto clay surfaces, react with carbonates to produce lead carbonates, associate with iron and manganese oxides, react with sulfides, associate with organic matter, or react with compounds such as phosphates, sulfates, and aluminum. Because sand is chemically inert compared to most soils, over time the amount of lead ions that escape the berm to either surface or ground water could be expected to increase, primarily because less inert soils will potentially sorb lead. Unamended sand is generally lower in carbonates, iron and manganese oxides, sulfides, organic matter, and phosphate compounds. Because of the inherent limitations of sand for containing lead following firing and under long-term weathering conditions, the technology proposed incorporates berm amendments that will buffer the sand berm $\mathrm{pH}$ and react with lead ions produced during the inevitable metallic lead corrosion.

\section{Apatite II}

Apatite II is produced, mechanically or enzymatically, from fish industry byproducts. This results in a composition of clean and dried fish bone and fish hard parts. The major elements of bones are calcium (Ca), phosphorus $(\mathrm{P})$, sulfur (S), and magnesium $(\mathrm{Mg})$ as well as several minor elements 
(Shinomiya et al. 1998). A study conducted by Shinomiya et al. (1998) investigated the eventual demineralization of mammal bones buried underground for 2 years and determined that phosphorous concentrations initially decreased within the bone and then increased, potentially due to nucleation sites (Wright et al. 2004) provided by the bone material. As a soil amendment, Apatite II has several advantages over other forms of natural apatite and terrestrial bone sources (e.g., cow bone). Apatite II has low trace metals concentrations and exhibits poor crystallinity compared to other naturally occurring forms of apatite (Conca et al. 2000). Unlike cow bones, Apatite II is highly microporous (Wright et al. 2004; Lu et al. 2001), and thus provides a readily available and reactive source of soluble phosphates along with a potential seed crystal for heterogeneous nucleation of lead-pyromorphites (Wright et al. 2004). Depending on the presence of certain metals in solution, a lead removal efficiency of 37 to 100 percent can be achieved through the process of hydroxyapatite dissolution and hydroxypyromorphite $\left[\mathrm{Pb}_{10}\left(\mathrm{PO}_{4}\right)_{6}(\mathrm{OH})_{2}\right]$ precipitation (Ma et al. 1994; Wright et al. 2004).

Stack et al. (2004) conducted a study of lead-pyromorphite growth on a galena $(\mathrm{PbS})$ surface. They determined that, as the surface released aqueous $\mathrm{Pb}^{2+}$, the lead reacted with aqueous phosphate, and the particles appeared to grow rapidly once nucleation was established. Using electrochemical scanning tunneling microscopy (EC-STM), they also determined that the particle adhesion forces could easily be overcome if a small force was applied. Cao et al. (2003) investigated several outdoor shooting ranges, and those that contained acidic soils with high concentrations of phosphates formed hydroxypyromorphites, thus having decreased lead mobility off range. Martinez et al. (2004) studied the effects of adding ligands and humic acids to lead-phosphate minerals. After looking at three ligands, they determined that, if the ligand contained an '-SH' functional group, it would create a soluble lead-ligand complex, and at a high $\mathrm{pH}$ the functional groups on the humic acids became deprotonated, thus increasing their chelating ability.

Apatite II was used at the Camp Stanley Storage Activity in Boerne, TX to remediate lead-contaminated soils. First, the large bullet fragments were separated from the soil by screening, after which Apatite II was mixed into the screened, metal-contaminated soil. A vegetative cap was established over the untreated soil and the Apatite II treated area. The average lead leachate concentration of the untreated area at Camp Stanley was 
$0.373 \mathrm{mg} / \mathrm{L}$, whereas the average lead leachate concentration of the Apatite II treated area was $0.003 \mathrm{mg} / \mathrm{L}$ (Wright et al. 2004). The TCLP results for both the treated and untreated soils were well below the EPA's regulatory level of $5 \mathrm{mg} / \mathrm{L}$. However, the TCLP lead concentrations for the Apatite II treated soil were, on average, 78 percent less than the untreated soil (Wright et al. 2004).

\section{Buffer Blocks}

Buffer Blocks offer a potential system to maintain the alkalinity of ballistic sand as a trapping medium and provide reagents that react with metal (especially lead) ions in solution to form insoluble precipitates. This new buffer system builds on previous ESTCP-funded demonstrations by the U.S. Army Corps of Engineers (USACE) of shock absorbing concrete, the USACE's previous patent on buffer systems in foamed concrete, U.S. Patent 6,264,735 (2001), and on the improvement patent U.S. Patent 6,620,236 (2003). When used in a Passive Reactive Berm (PRBerm), these amendments are expected to provide long-term metal recovery/ stabilization in active berms and runoff control to mitigate migration of metals.

The application of phosphate in the form of calcium phosphate has been shown to immobilize lead that is normally released into the environment by the natural weathering or corrosion of bullet fragments in soil. The USACE has been adding phosphate to shock-absorbing concrete to limit the mobilization of lead since 1997 (USPTO 2001). In addition, USACE has also developed a low-lead leaching SACON ${ }^{\circledR}$ formulation that uses phosphate and aluminum compounds (USPTO 2003). USACE has been working with an industry partner (Super Trap, Inc.) that makes and sells blocks of foamed mortar that contain calcium phosphate and aluminum hydroxide. These buffer blocks have been investigated for use to assist in controlling the release of lead in granular rubber bullet traps as well as other media (such as ballistic sand or soil berms) used to collect bullets. Placing finely ground lead-reactive compounds such as calcium phosphate and aluminum hydroxide directly into the high hydraulic conductivity sand or rubber chips would result in rapid flushing of the additive from the berm with rain events. Working these materials into frangible, nonricocheting foamed mortar blocks allows the powdered buffer to be supplied continuously as the blocks are broken by impacting bullets. A patent has been applied for this innovation as well (USPTO 2005). 
The calcium phosphate/aluminum hydroxide buffer block system operates in several ways. The aluminum and phosphate react with lead in solution to produce lead-aluminum phosphate. Lead-aluminum phosphate is a very stable, insoluble compound ( $\log \mathrm{K}_{\mathrm{sp}}=-99.3$ ) that forms naturally during the weathering of lead ores. Naturally occurring lead aluminum phosphate (the mineral plumbogummite) occurs as colloform masses that suggest the compound forms as a gel and that the crystalline phase forms from the gel. The buffer can be formulated to maintain a desired leachate water $\mathrm{pH}$ from 7 to 11, thus reducing both the rate of corrosion and the solubility of lead compounds.

To evaluate changes in leaching of soluble lead from berms amended with Buffer Blocks, crushed blocks were mixed with lead powder to form a mixture that contained 1 percent metallic lead. After aging for several weeks in a moist condition, the contaminated Buffer Block was subjected to TCLP testing. A TCLP lead concentration of $0.35 \mathrm{mg} / \mathrm{L}$ was observed for the Buffer Block treated sand, while a lead concentration of $279 \mathrm{mg} / \mathrm{L}$ was in the ballistic sand with 1 percent metallic lead.

\section{SulfiTech A/T}

SulfiTech A/T (U.S. Patents 6,476,287 B1 and 6,680,039) is an oxidatively stabilized sulfite-based treatment system that reacts with water- or acidsoluble forms of lead to form the insoluble mineral Scotlandite ( $\mathrm{PbSO}_{3}$, lead sulfite) (USPTO 2002 and 2004).

The SulfiTech A/T reagent has a very low solubility in water, and is therefore resistant to wash out. In addition, it is not water reactive and is expected to control lead solubility over the long term even when the application area is left exposed to weather. This technology is designed to address both high acidity soils that allow high concentrations of lead in leachate and surface water, and the sites such as Barksdale AFB with high clay content soils that suspend well.

The treatability study uses amendments that can potentially form minerals that are very insoluble. The amendments selected for investigation in this study (Apatite II, SulfiTech A/T, and the Buffer Blocks) provide potentially insoluble metal complexes (Table 1) as compared to other insoluble lead complexes. 
Table 1. Solubility products of selected lead minerals.

\begin{tabular}{|c|c|c|}
\hline Mineral & Chemical Formula & $\log K_{s p} 1$ \\
\hline Lead chloride & $\mathrm{PbCl}_{2}$ & -4.8 \\
\hline Anglesite & $\mathrm{PbSO}_{4}$ & -7.8 \\
\hline Cerussite & $\mathrm{PbCO}_{3}$ & -12.8 \\
\hline Fluoropyromorphite & $\mathrm{Pb}_{5}\left(\mathrm{PO}_{4}\right)_{3} \mathrm{~F}$ & -71.6 \\
\hline Hydroxypyromorphite & $\mathrm{Pb}_{5}\left(\mathrm{PO}_{4}\right)_{3} \mathrm{OH}$ & -76.8 \\
\hline Bromopyromorphite & $\mathrm{Pb}_{5}\left(\mathrm{PO}_{4}\right) \mathrm{Br}$ & -78.1 \\
\hline Pyromorphite $^{2}$ & $\mathrm{~Pb}_{5}\left(\mathrm{PO}_{4}\right)_{3} \mathrm{Cl}$ & -84.4 \\
\hline Hindsdalite & $\mathrm{PbAl}_{3}\left(\mathrm{PO}_{4}\right)\left(\mathrm{SO}_{4}\right)(\mathrm{OH})_{6}$ & -99.1 \\
\hline Plumbogummite $^{2}$ & $\mathrm{PbAl}_{3}\left(\mathrm{PO}_{4}\right)_{2}(\mathrm{OH})_{5} \cdot\left(\mathrm{H}_{2} \mathrm{O}\right)$ & -99.3 \\
\hline Corkite & $\mathrm{PbFe}_{3}\left(\mathrm{PO}_{4}\right)\left(\mathrm{SO}_{4}\right)(\mathrm{OH})_{6}$ & -112.6 \\
\hline Scotlandite $^{2}$ & $\mathrm{PbSO}_{3}$ & $\begin{array}{l}\text { Insoluble in water } \\
\text { Soluble in } \mathrm{HNO}_{3}{ }^{3}\end{array}$ \\
\hline \multicolumn{3}{|c|}{$\begin{array}{l}1 \text { Log of the solubility product at } 25^{\circ} \mathrm{C} \text {; cited in Traina and Laperche (1999). } \\
2 \text { Potential amendment minerals produced in this study are in bold. } \\
3 \text { Qualitative solubility as listed in CRC (2004). }\end{array}$} \\
\hline
\end{tabular}

\section{Objectives}

The specific objectives of this treatability study were:

- Determine the appropriate ballistic sand for use in the PRBerm field demonstration at the Barksdale AFB SAFR.

- Determine the appropriate sand to amendment ratio for use in the field demonstration at an active SAFR.

- Conduct treatability studies to determine the appropriate PRBerm amendment(s) to use in a field demonstration at the Barksdale AFB SAFR that will:

- Keep lead and copper concentrations below the surface water permit limits of $0.150 \mathrm{mg} / \mathrm{L}$ and $0.500 \mathrm{mg} / \mathrm{L}$, respectively, - Maintain a pH between 6 and 9 in the leachate and runoff waters, - Maintain a TOC at less than $50 \mathrm{mg} / \mathrm{L}$ for the leachate and runoff waters.

- Use the treatability study results in the development of a BMP for application of the PRBerm at appropriate SAFRs. 


\section{Experimental Design}

This study focused on the application of amendments to SAFR ballistic sand under controlled batch scale and mesoscale studies that mimic the field environmental conditions at SAFRs. Lead-contaminated ballistic sand was generated by firing M-16 $(5.56 \mathrm{~mm})$ bullets into a collection box that contained well-graded sand. Amendment and sand selection were determined through two lysimeter studies, an amendment aging study, and a column study.

Special lysimeters were constructed for the application of simulated rainfall to large volumes of treated and untreated sand. They were designed to accommodate the collection of the leachates passing through the ballistic sand mass as well as the runoff from the sand surface. Measured rainfall was applied to the sand mass in weekly applications over a 4-month (16-week) period. One lysimeter study used lead-contaminated sand that had just been fired upon and had only aged for about 2 weeks. The other lysimeter study used lead-contaminated sand that had been aged for 4 months using a weekly wetting and drying cycle followed by a month without water application.

\section{Amendment studies}

\section{Amendment selection}

Three amendments were selected for use in the treatability studies. These amendments were Apatite II, SulfiTech A/T, and Buffer Blocks. The Apatite II and Buffer Block amendments combined with 1,00o mg Pb/kg SAFR berm soil were subjected to three leaching techniques to determine the appropriate amendment ratios to use in the PRBerm: TCLP, Distilled Deionized Water Suspend and Settle (DDI S\&S), and a 3-day leaching procedure. The leaching procedure performance was measured against TCLP regulatory limits as well as for significant reduction (e.g., 90 percent) compared with the controls (unamended SAFR berm soil) evaluated in the batch-scale experiments.

\section{Aged amendment study}

During Lysimeter Study I, elevated dissolved organic carbon (DOC) and odor were observed in the Apatite II amended lysimeter cells. An aging 
study was conducted in order to determine the effects of aging of Apatite II on lead reduction using sorption experiments. Apatite II was baked in a muffle furnace, open to the atmosphere, at approximately $475 \pm 25^{\circ} \mathrm{C}$ for 72 hours to remove the 35 percent organics typically associated with the mechanically produced Apatite II. The Apatite II and Baked Apatite II amendments were placed into clear glass jars; the jars were then filled with reagent grade water at a 1:5 amendment to solution ratio (w:v). The aged Apatite II solution was subjected to sorption studies and analytical analysis.

\section{Column study}

In addition to the conclusions drawn from the amendment selection and aging studies, saturated and intermittent (i.e., allowing for wetting and drying cycles) column studies were conducted to evaluate the soil amendments prior to starting the second lysimeter study. The focus amendments were selected from the results obtained in the amendment studies and the first lysimeter study. Mechanically and enzymatically produced Apatite II, Baked Apatite II, SulfiTech A/T, and Buffer Block \# 5 were selected for investigation in the column studies. Baked Apatite II was prepared by placing approximately $1 \mathrm{~kg}$ of mechanically produced Apatite II into a $475{ }^{\circ} \mathrm{C}$ muffle furnace for 24 hours. The Buffer Block \# 5 was prepared by using the Buffer Block \#4 formulation and carbonating it during the curing process, creating Buffer Block \#5 with a near neutral $\mathrm{pH}$.

\section{Lysimeter studies}

\section{Lysimeter Study I}

The first study used five mesoscale lysimeter cells loaded with leadcontaminated ballistic sand at an approximate concentration of $9,400 \mathrm{mg} / \mathrm{kg}$ (Table 2). One lysimeter cell was a control with no amendment added. One lysimeter cell contained 4.5 percent aluminum/ phosphate amended Buffer Blocks (Buffer Block \#4), and the remaining three lysimeter cells were treated with 3,5 , and 8 percent (w/w) of the Mechanical Apatite II amendment. On a weekly basis, reverse osmosis (RO) water with a $\mathrm{pH}$ of approximately 5.5 was supplied to the five lysimeters. The mesoscale lysimeter cells were left uncovered and open to the atmosphere during the study. 
Table 2. Experimental design for Lysimeter Studies I and II.

\begin{tabular}{|c|c|c|c|c|}
\hline \multirow{3}{*}{$\begin{array}{l}\text { Lysimeter } \\
\text { Cell }\end{array}$} & \multicolumn{4}{|c|}{ Project Description } \\
\hline & \multicolumn{2}{|c|}{ Study I } & \multicolumn{2}{|c|}{ Study II } \\
\hline & Amendment & Water Addition & Amendment & Water Addition \\
\hline 1 & $\begin{array}{l}\text { Control } \\
\text { no amendment }\end{array}$ & \multirow{8}{*}{$\begin{array}{l}46.3 \mathrm{~L} \text { of } \mathrm{RO} \text { water } \\
\text { applied per week } \\
\text { (or approx } 2.94 \mathrm{in} . \\
\text { per week) }\end{array}$} & $\begin{array}{l}\text { Control } \\
\text { no amendment }\end{array}$ & \multirow{8}{*}{$\begin{array}{l}3.8 \mathrm{~L} \text { of RO water } \\
\text { applied per week } \\
\text { (or approx } \\
2.94 \text { in. per } \\
\text { week) }\end{array}$} \\
\hline 2 & $\begin{array}{l}\text { 3\% Mechanical } \\
\text { Apatite II (w/w) }\end{array}$ & & $\begin{array}{l}5 \% \text { Baked } \\
\text { Apatite II (w/w) }\end{array}$ & \\
\hline 3 & $\begin{array}{l}5 \% \text { Mechanical } \\
\text { Apatite II (w/w) }\end{array}$ & & $\begin{array}{l}5 \% \text { Mechanical } \\
\text { Apatite II (w/w) }\end{array}$ & \\
\hline 4 & $\begin{array}{l}\text { 8\% Mechanical } \\
\text { Apatite II (w/w) }\end{array}$ & & $\begin{array}{l}5 \% \text { Enzymatic } \\
\text { Apatite II }(w / w)\end{array}$ & \\
\hline 5 & \begin{tabular}{|l|}
$4.5 \%$ Buffer \\
Block \#4 (w/w)
\end{tabular} & & $\begin{array}{l}\text { 5\% SulfiTech } \\
(w / w)\end{array}$ & \\
\hline 6 & & & $\begin{array}{l}\text { 1\% Buffer Block } \\
\# 5(w / w)\end{array}$ & \\
\hline 7 & & & $\begin{array}{l}\text { 3\% Buffer Block } \\
\# 5(w / w)\end{array}$ & \\
\hline 8 & & & $\begin{array}{l}\text { 5\% Buffer Block } \\
\# 6(w / w)\end{array}$ & \\
\hline
\end{tabular}

\section{Lysimeter Study II}

To accommodate smaller volumes of berm material, scaled-down lysimeter cells were designed to hold approximately $1 / 12$ th of the volume of the larger lysimeter cells. Lysimeter Study II used eight smaller lysimeter cells loaded with the $9,400 \mathrm{mg} / \mathrm{kg}$ lead-contaminated berm sand from the control cell used in Lysimeter Study I. The experimental design for Lysimeter Study II is also shown in Table 2. The control (unamended) berm sand from Lysimeter Study I was aged with RO water wetting and drying cycles over a 4-month period, followed by a month with no water application. In Lysimeter Study II, one lysimeter cell was used as the control with no amendment added. Three lysimeter cells were each treated with 5 percent $(\mathrm{w} / \mathrm{w})$ of different Apatite II amendments (mechanically produced, enzymatically produced, and thermally treated or Baked Apatite II). One lysimeter cell was treated with a 5 percent sulfur amendment (SulfiTech A/T), and three more lysimeter cells were treated with 1 , 3 , and 5 percent of near neutral $\mathrm{pH}$ alumina/phosphate enhanced Buffer Blocks (Buffer Block \#5). 


\section{Materials and Methods}

\section{Instrumentation}

To determine the appropriate sand and amendments to be used in the PRBerm field demonstration, the ballistic sand and amendments were evaluated in several treatability studies. The sand was subjected to particle size separation, angle of repose, and cost analysis. The amendments were subjected to several leaching procedures with lead-contaminated SAFR berm material in order to determine the appropriate amount to add to the PRBerm. The amendments were also subjected to lysimeter studies in order to understand and characterize the leachate and runoff waters generated from an equivalent amount of annual rainfall on the amended SAFR berm sand. Throughout the report, the methods and procedures detailed in Table 3 were used for chemical and physical analysis of the PRBerm application. Table 4 lists the estimated instrument detection limits (IDLs) for each compound of concern.

Table 3. Chemical and physical analytical procedures used during the treatability studies.

\begin{tabular}{|c|c|c|}
\hline \multirow[b]{2}{*}{ Parameter/Procedure } & \multirow[b]{2}{*}{ Method } & Detection Limit \\
\hline & & Aqueous, $\mathrm{mg} / \mathrm{L}$ \\
\hline Digestion procedures & \begin{tabular}{|l|} 
SW-846-3051 \\
SW-846-3015
\end{tabular} & 0.01 \\
\hline $\mathrm{DOC}$ & $\begin{array}{l}\text { SW-846-9060 } \\
\text { SOP }\end{array}$ & 1.0 \\
\hline TCLP & SW-846-1311 & $0.05 / 0.01$ \\
\hline DDI S\&S & $\begin{array}{l}\text { SW-846-1311 } \\
\text { ASTM D4874-95 }\end{array}$ & $0.05 / 0.01$ \\
\hline Angle of Repose & ASTM D4874-95 & n.a. \\
\hline Particle size distribution & SOP & n.a. \\
\hline Moisture content & ASTM D4874-95 & n.a. \\
\hline ICP-AES ${ }^{3}$ & Method 200.7 & $0.05 / 0.01$ \\
\hline
\end{tabular}


Table 4. Estimated Instrument Detection Limits for compounds of concern.

\begin{tabular}{|l|l|l|}
\hline Compound & Estimated IDL $1, \mathrm{mg} / \mathrm{L}$ & ICP-AES IDL ${ }^{2}, \mathrm{mg} / \mathrm{L}$ \\
\hline Lead $(\mathrm{Pb})$ & 0.028 & 0.010 \\
\hline Chromium (Cr) & 0.005 & 0.010 \\
\hline Copper (Cu) & 0.004 & 0.010 \\
\hline Nickel (Ni) & 0.010 & 0.010 \\
\hline Zinc (Zn) & 0.001 & 0.010 \\
\hline Iron (Fe) & 0.004 & 0.010 \\
\hline Manganese (Mn) & 0.001 & 0.010 \\
\hline Molybdenum (Mo) & 0.005 & 0.010 \\
\hline Vanadium (V) & 0.005 & 0.010 \\
\hline Antimony (Sb) & 0.021 & 0.010 \\
\hline Calcium (Ca) & 0.007 & 0.010 \\
\hline 1 For metals adapted from SW-846 Method 6010B, Table 1. \\
2 IDL of 0.010 ppm (mg/L) used for stated calculations in the report.
\end{tabular}

\section{Sand selection}

Five different sand types were selected from local vendors within a 150 mile radius of Barksdale AFB. The five sands were analyzed and compared using the following criteria:

- Particle size distribution

- Residual metals concentrations

- Cost to deliver the sand

- Angle of repose

- Moisture content of the sand.

\section{Amendment studies}

\section{Amendment selection}

TCLP. Following USEPA SW 846 Method 1311, TCLP was performed on the Apatite II and Buffer Block amendments to determine the toxicity characteristics of the 1,000 mg Pb/kg laden amended berm soil. A 1:20 (w:v) soil-to-extraction solution ratio was used where 5 percent of the soil matrix was composed of the amendments Apatite II and/or Buffer Block. 
The samples were placed on a tumbler for $18 \pm 2$ hours. After tumbling, an aliquot of the sample was removed and placed on a centrifuge after which approximately $60 \mathrm{~mL}$ of sample was filtered through a $0.45 \mu \mathrm{m}$ syringe filter and analyzed for metals. Four different Buffer Blocks were evaluated at 5 percent by weight percentage of the soil matrix. The Buffer Blocks were designated by their different Elixir types: \#1, 2, 3, and 4. Different percentages of Apatite II were evaluated to determine the appropriate amount to add: $1,3,5$, and 10 percent by weight.

$D D I$ S\&S. The DDI S\&S procedure is a water-leaching test, a modification of the TCLP procedure. An amended soil-to-DDI S\&S water ratio of 1:20 (w:v) was maintained, similar to the TCLP procedures. The same amendment types and ratios used in the TCLP were used in the DDI S\&S with the addition of a 2.5 percent Apatite II and 2.5 percent Buffer Block Elixir \#4 soil amendment. The samples were placed on a shaker table for 1 hour then allowed to settle for $18 \pm 2$ hours. After settling, aliquot samples were removed, filtered, and analyzed for metals.

In the 3-day leaching procedure adapted from Tardy et al. (2003), the $1,000 \mathrm{mg} / \mathrm{kg}$ SAFR soil/amendment matrix was mixed with DDI water in a 1:10 ratio (w:v), and tumbled for 3 days. The $\mathrm{pH}$ was sampled daily, and the final metals concentrations in solution after 3 days of tumbling were determined. Previous leaching studies on Apatite II and Buffer Block indicated that 5 percent by weight of the soil amendment would be sufficient to retain greater than 90 percent of the lead in the soil matrix under TCLP conditions. For the 3 -day leaching procedure, the $1,000 \mathrm{mg} \mathrm{Pb} / \mathrm{kg}$ berm soil contained 5 percent by weight of the following amendments: Whole Bone Apatite II, Crushed Bone Apatite II, and Buffer Block Elixir \#4. After tumbling, triplicate aliquot samples were removed, filtered, and analyzed for metals and $\mathrm{pH}$.

\section{Column studies}

Following a modified method of ASTM D-4874-95 (2001), columns were made from 2-in. $(5.08 \mathrm{~cm})$ internal diameter (ID) clear rigid PVC (polyvinyl chloride) tubing. Each column was assembled and prepared in the same manner using threaded adapters, threaded bushing, and 3/8th in. $(0.95 \mathrm{~cm})$ speedfit valves. The $3 / 8$ th in. $(0.95 \mathrm{~cm})$ Masterflex high-density polyethylene (HDPE) tubing was attached to each bottom adaptor for collection. A 2-in. (5.08 cm) cap slip was placed on top of each column during the saturated column study. Seven columns were prepared using 
the $9,400 \mathrm{mg} / \mathrm{kg}$ lead-contaminated Red River sand. The column study consisted of columns containing 5 percent amendments of mechanically and enzymatically produced Apatite II, Baked Apatite II, SulfiTech A/T, and Buffer Block \#5 respectively, as well as a control berm sand (with no amendment) and a clean control (Red River) sand.

Two column studies were conducted. The first study examined a saturated soil situation; the second employed an intermittent water flow. The column studies were conducted over 32 wetting events (approximately 5 months) allowing for saturated and intermittent wetting conditions within the column. An initial 120-mL of RO water was allowed to flow through the columns in order to wet the soil within the columns. For both column studies, the leachate was collected in 125-mL Nalgene bottles. Filtered and total leachate metals were determined as in the lysimeter studies. The filtered and digested samples were analyzed for metals $(\mathrm{Pb}$, $\mathrm{Cr}, \mathrm{Cu}, \mathrm{Ni}, \mathrm{Zn}, \mathrm{Fe}, \mathrm{Mo}, \mathrm{Mn}, \mathrm{V}$, and $\mathrm{Sb}$ ) and phosphorous concentrations.

Saturated column. During the saturated column study, $120-\mathrm{mL}$ of RO water was added to the columns two times per day for a total of 16 wetting events. The water was allowed to flow through the columns under the force of gravity.

Intermittent column. During the intermittent column study, 120-mL of RO water per week was added to the columns over 16 weeks. The water was allowed to flow through the column under the force of gravity.

\section{Aged amendment studies}

The aged amendment study involved three different sorption experiments with a similar lead solution $\mathrm{pH}$ of approximately 5.1:

- Stirred sorption: Aged Mechanical and Baked Apatite II amendment samples were mixed in beakers with a known lead concentration solution for 30 minutes. The solution was analyzed for soluble lead concentration and $\mathrm{pH}$.

- Semi-static sorption: Aged Mechanical and Baked Apatite II amendment samples were placed into plastic bottles with a known lead concentration solution, placed on a shaker table for 10 minutes, and allowed to remain static for $18 \pm 2$ hours before liquid samples were removed for soluble lead concentration analysis. 
- Static sorption: Aged Mechanical, Enzymatic, and Baked Apatite II amendment samples were placed into plastic bottles with a known lead concentration solution and were allowed to remain static for $18 \pm 2$ hours before liquid samples were removed and analyzed for total and soluble lead concentrations.

Multiple batches of aged material were prepared and used to measure available DOC and to conduct the sorption experiments. In order to maintain a 1:5 amendment-to-solution ratio during aging, reagent grade water was re-supplied as needed to the aging jars as liquid was lost due to evaporation or removal of samples. The moisture content of the saturated Apatite II and Baked Apatite II was determined by using ASTM D4874-95 (2001).

Aged Mechanical, Enzymatic, and Baked Apatite II samples were used to determine soluble lead reduction, the DOC production, and soluble phosphorous associated with the aging process. During the aging process, portions of the aged media were removed from the jars and used in the sorption experiments. In addition, aliquot samples were removed from the aged jars to determine the DOC in solution. After Day 5 of aging for the semi-static sorption aging containers, the Apatite II solution was centrifuged for 10 minutes at 3,000 revolutions per minute (rpm) and then the supernatant was filtered through a $0.45 \mu \mathrm{m}$ filter and prepared for DOC analysis. All other samples were filtered through a $0.45 \mu \mathrm{m}$ filter and prepared for DOC analysis.

Liquid samples were filtered using a $0.45 \mu \mathrm{m}$ filter, covered, and stored at $4{ }^{\circ} \mathrm{C}$ if they were not immediately analyzed. A modified EPA Method 200.7 was used to analyze liquid samples for soluble and total digest concentrations for lead using the Optima 4300 DV ICP-AES, with a method detection limit of $0.050 \mathrm{mg} / \mathrm{L}$ for lead and $5 \mathrm{mg} / \mathrm{L}$ for phosphorous. A Fisher Scientific AR50 pH meter was used to measure the effects the aged Apatite II and Baked Apatite II had on the solution pH. The DOC was measured by using a Shimadzu TOC-V/SSM-5000A analyzer following prescribed methods (Table 3). 


\section{Lysimeter design and operation}

\section{Lysimeter design}

Berm dimensions and resulting slopes vary at SAFRs, so design of the large-scale lysimeters was intended to replicate and understand the soil conditions more than replicate the physical slope and dimension of the SAFR berm. A cross section of the berm lysimeter designed for this study is illustrated in Figure 1. The lysimeter was made from three-fourths-inch thick, high-density polyethylene and measured $0.787 \mathrm{~m}$ (31 in.) by $0.787 \mathrm{~m}$ by $0.609 \mathrm{~m}$ (24 in.) (inside length $\times$ width $\times$ height). The lysimeters were placed on stands constructed from angle iron where the angle could be adjusted to control runoff and leachate collection.

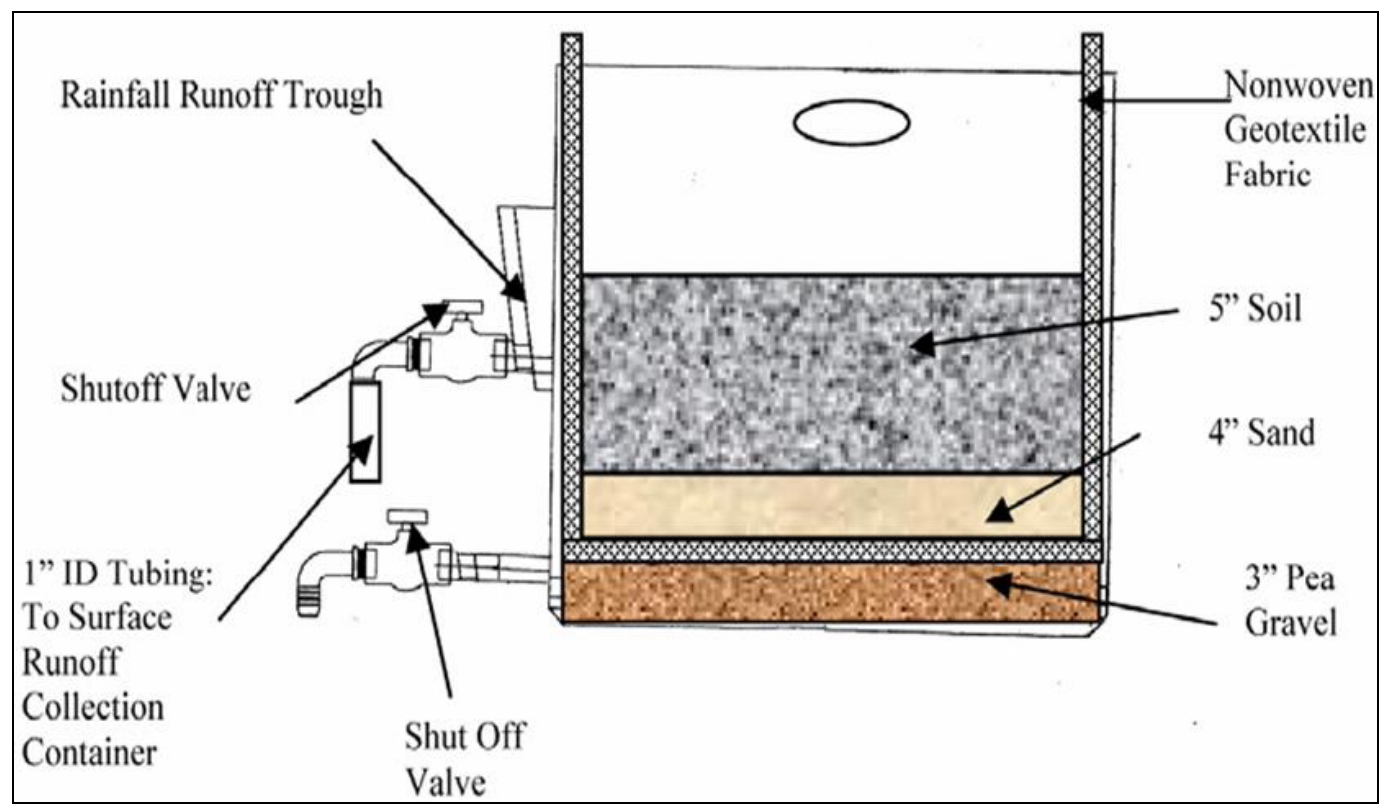

Figure 1. Cross section of lysimeter.

\section{Surface runoff and leachate collection system}

The lysimeters were designed to allow for the collection of leachate flowing through the soil as well as runoff from the soil surface (Figures 2 and 3). Sufficient room remained above the soil mixture for a portion of the simulated rain to puddle and flow through the runoff and leachate collection systems. Leachate and runoff waters were collected in polyethylene buckets. All tubing in the collection system was made from nonreactive silicon or polyethylene. 


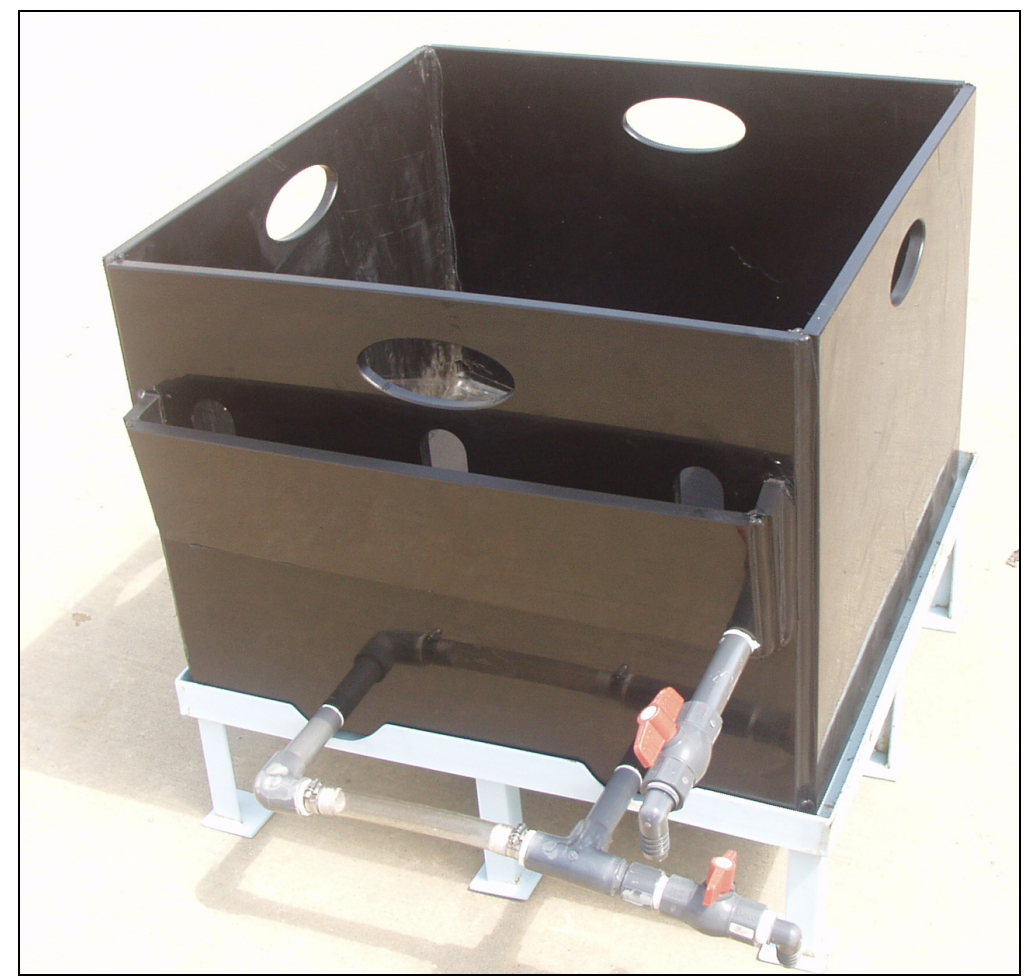

Figure 2. Empty lysimeter cell showing leachate and runoff collection systems.

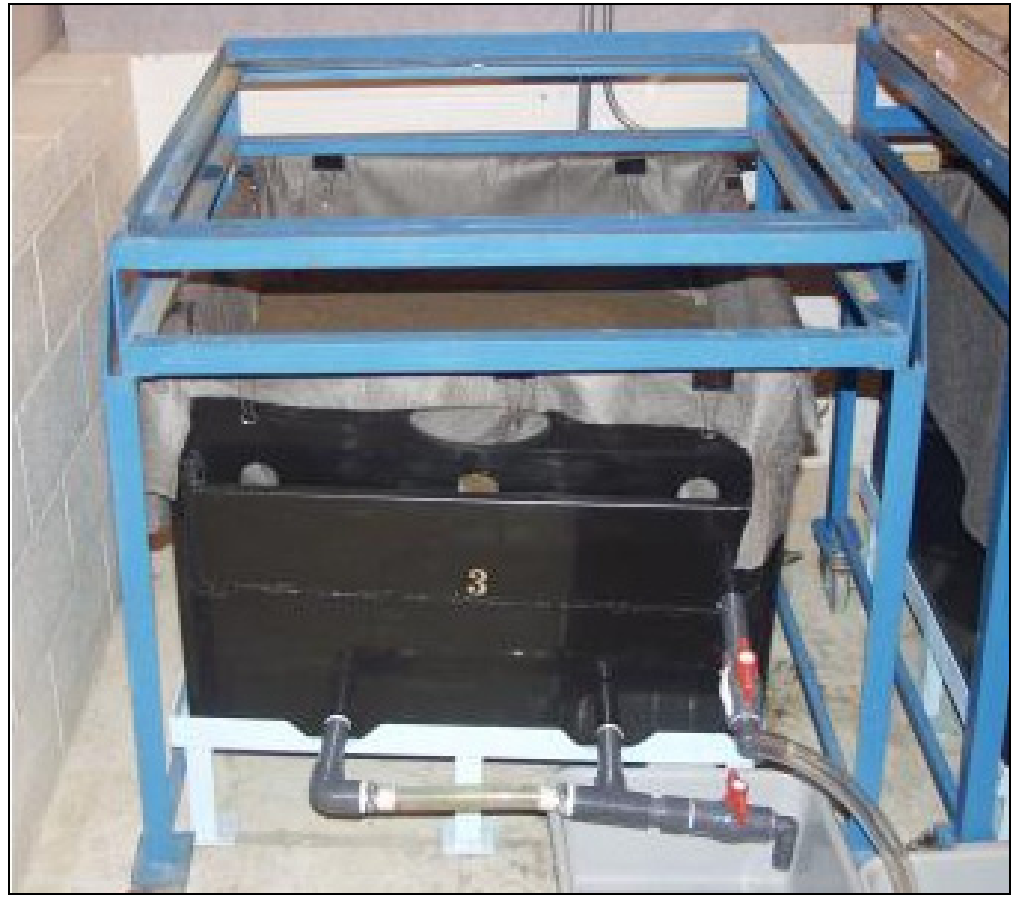

Figure 3. Lysimeter showing rainfall simulator holding frame and water collection system. 


\section{Simulated rainfall}

The artificial rainwater was introduced through a rainfall simulator made from a clear plexiglas box that rested directly above the top of the lysimeters on a metal frame (Figure 3). The rainfall simulator was designed to apply air pressure through regulators fitted into the top of the simulator to vary the airflow and rainfall rates as needed. A porous polyethylene material was secured to the bottom of the plexiglas box using silicone adhesive caulk. A reservoir containing RO water was placed on top of the simulator box to supply a measured amount of the leaching fluid (rainwater) into the box. The fluid flowed through the porous bottom of the rainfall simulator onto the test soil. Simulated rainfall was applied to each lysimeter over a 16-week period to replicate a total average annual rainfall of $47 \mathrm{in}$. (typical for the Barksdale AFB area).

\section{Sand preparation and lysimeter loading procedures}

After the appropriate sand was selected, a bulk sample was obtained from the vendor and placed in 55-gal, polyethylene-lined drums. The sand was taken to a local SAFR and, with the assistance of a military unit, M-16 rifles were used to fire 0.223 caliber $(5.56 \mathrm{~mm})$ rounds into the sand to generate a calculated lead concentration (Table 5) of approximately $9,400 \mathrm{mg} / \mathrm{kg}$ (Figure 4). The fired upon sand was collected and placed in 55-gal, polyethylene-lined drums for storage until use in the lysimeter studies.

Table 5. Calculated metals concentration based on sand and number of rounds fired.

\begin{tabular}{|c|c|c|c|c|c|}
\hline Metal & $\begin{array}{l}\text { Mass per } \\
\text { Round, g }\end{array}$ & $\begin{array}{l}\text { Number } \\
\text { Bullets Fired }\end{array}$ & $\begin{array}{l}\text { Mass per Total } \\
\text { Rounds Fired, g }\end{array}$ & $\begin{array}{l}\text { Mass of } \\
\text { Sand, kg }\end{array}$ & $\begin{array}{l}\text { Concentration } \\
\text { in Sand, } \mathrm{mg} / \mathrm{kg}\end{array}$ \\
\hline Total Metal & $4.0058^{1}$ & \multirow{8}{*}{5,800} & n.a. ${ }^{2}$ & \multirow{8}{*}{1,270} & n.a. \\
\hline Lead & 2.0535 & & 11,910 & & $9,378^{3}$ \\
\hline Copper & 1.1547 & & 6,697 & & 5,274 \\
\hline Zinc & 0.1270 & & 736 & & 580 \\
\hline Iron & 0.6357 & & 3,686 & & 2903 \\
\hline Manganese & 0.0049 & & 28 & & 22 \\
\hline Antimony & 0.0207 & & 120 & & 95 \\
\hline Other Metals & 0.0093 & & 53 & & 42 \\
\hline \multicolumn{6}{|c|}{$\begin{array}{l}1 \text { Total mass is based on the M855 ball round and accounts for additional trace metals } \\
\text { found in the bullet that are not listed. } \\
2 \text { n.a. = not applicable. } \\
3 \text { For purposes of clarity, the calculated reference concentration is given as the rounded } \\
\text { value of } 9,400 \mathrm{mg} / \mathrm{kg} \text {. }\end{array}$} \\
\hline
\end{tabular}




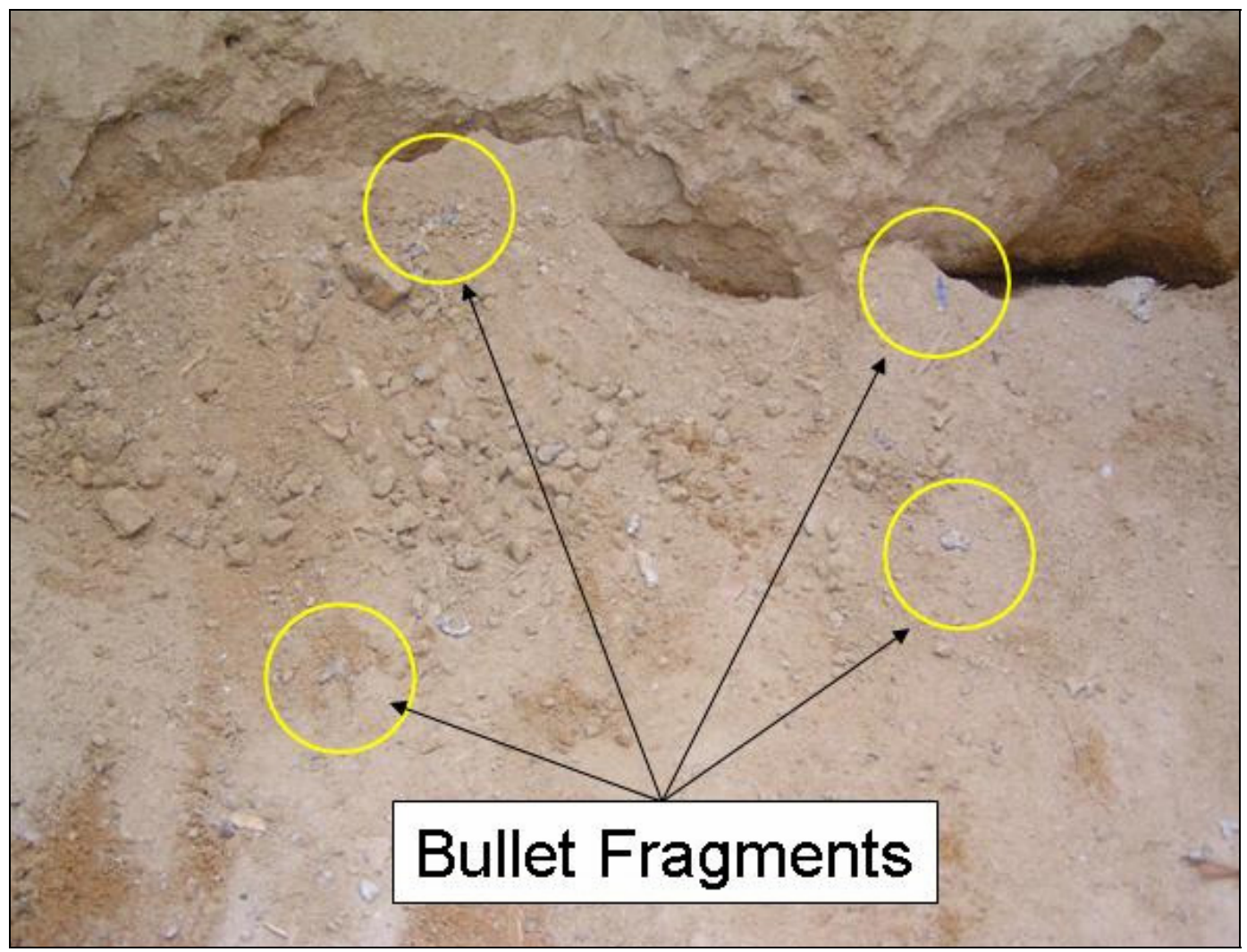

Figure 4. Generation of approximately $9,400 \mathrm{mg} \mathrm{Pb} / \mathrm{kg}$ sand.

All the berm sand was removed from the catch box (Figure 4) and homogenized by placing the bulk material into a large rectangular box (Figure 5). The primary impact area of the bullets in the catch box potentially contained the vast majority of the metals from the bullet impact, so the berm sand was homogenized to ensure that the distribution of metals was uniform within the berm sand. The bulk sample was quartered, split, and mixed, then remixed as the bulk sample. This process was repeated nine times. Rakes, shovels, and a hand-held tiller were used to thoroughly mix the sand. Nine subsamples were removed (Figure 5) to ensure that the bulk sample was well homogenized and to determine initial metals (i.e., lead) content of the berm sand. The sand was ground and then digested according to SW-846 Method 3051 (USEPA 1999).

Lysimeter Study I. The final homogenized bulk berm sand was divided into five lysimeter subsamples by systematically removing the sand from the large plastic box. Approximately $185 \mathrm{~kg}$ of berm sand was weighed and mixed in a rotary cement mixer for 15 minutes with the appropriate amount and type of amendment for the corresponding lysimeter. 


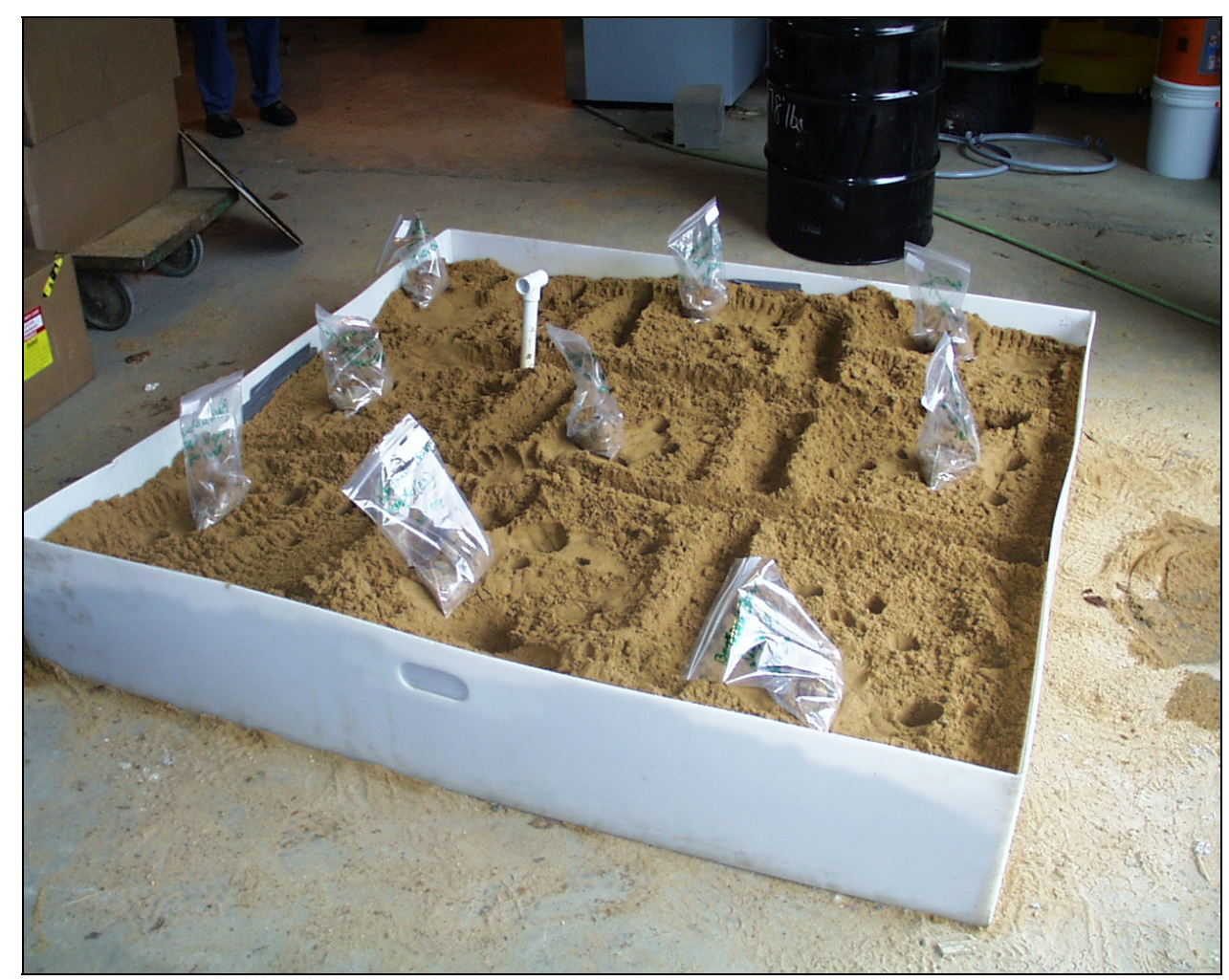

Figure 5. Mixing the sand to generate homogeneous bulk samples for use in the lysimeters. Nine subsamples were removed to determine initial sand metal (i.e., lead) concentrations.

Lysimeter Study II. The final homogenized bulk berm sand was divided into eight lysimeter subsamples by systematically removing the sand from the large plastic box. Approximately $16 \mathrm{~kg}$ of berm sand was weighed and mixed in a rotary "V-mixer" for approximately 15 minutes with the appropriate amount and type of amendment for the corresponding lysimeter.

The Buffer Block \# 5 was sieved and the fraction that was passed through the $25.0 \mathrm{~mm}$ sieve and retained on the $9.5 \mathrm{~mm}$ sieve was used in the lysimeter cells. On a weekly basis, RO water was supplied to the eight lysimeter cells, which were left uncovered and open to the atmosphere during the study.

Each lysimeter was loaded as shown in Figure 1. Prior to conducting the tests, the lysimeter cells were saturated with RO water supplied from a 6o-L polyethylene bottle. The reservoir bottle was placed on a tall mobile stand and positioned over each lysimeter. Pressurized water was forced into each lysimeter in an upward mode through all layers. After complete saturation occurred, as evidenced by a thin water layer on top of the soil mass, the excess water was drained from each lysimeter. 
For both lysimeter studies, during each rain event the runoff and leachate were collected in equal volumes. These samples were analyzed for $\mathrm{pH}$, Total Suspended Solids (TSS), DOC, which can also be referred to as Dissolved Total Organic Carbon (DTOC), and soluble and total liquid metals concentrations ( $\mathrm{Pb}, \mathrm{Cr}, \mathrm{Cu}, \mathrm{Ni}, \mathrm{Zn}, \mathrm{Fe}, \mathrm{Mn}, \mathrm{Mo}, \mathrm{V}$, and $\mathrm{Sb}$ ). The leachate and runoff samples were also analyzed for dissolved metals after filtering through a 0.45 -micrometer $(\mu \mathrm{m})$ filter following the procedures in Method 3010 (American Public Health Association 1998). Total (digested) metals concentrations were determined after digestion procedures according to SW-846 Method 3015. Metals concentrations were determined using SW-846 Method 6010B Inductively Coupled Plasma Atomic Emission Spectroscopy (USEPA 1999) on a Perkins Elmer Optima 4300 Dual View.

TCLP and DDI S\&S leaching extractions were performed on the treated and untreated $9,400 \mathrm{mg} / \mathrm{kg}$ lead-contaminated sand for the pre- and postLysimeter Study II berm sand. Metals concentrations were determined using ICP-AES. The evaluation of the characteristic leaching properties of the soils was done in order to further assess the effects of the sand amendments on the lead containment within the sand matrix. 


\section{Results and Discussion}

The results obtained from the batch-scale and full-scale lysimeter cell studies provided potential amendments for use in the field demonstration of the PRBerm. Not all of the amendments that can possibly be used in the PRBerm were studied due to lack of time and funding, but the results indicate that potential amendments do exist that will work at containing metals within the PRBerm matrix. Appendix A contains additional data results.

\section{Sand selection and preparation}

Different sand samples were selected from various vendors located within a 150-mile radius of Barksdale AFB. Six sand samples were identified and labeled as: Red River 01, 02/03; Tri-State Concrete 01/02; Tri-State Mason 01/02; Madden Screenings 01/02; and Play Sand. The Play Sand was analyzed for comparison purposes only. The Red River sand samples came from two different piles of sand; otherwise, the numerical designation behind the sample name indicates duplicate samples. The sand samples were characterized based on their particle size distribution, moisture content, angle of repose, cost of delivery, and digested metals concentrations. The discriminating factors in the selection of ballistic sand were the particle size distribution, cost of delivery, and digested metals concentrations.

The sand sample obtained from the Red River quarry proved to be the best locally available sand for the PRBerm. The Red River sand had more than 96 percent of the sand particles passing through the No. 4 sieve $(4.75 \mathrm{~mm})$ and retained on the No. 120 sieve $(125 \mu \mathrm{m})$ (Tables 6 and 7). In addition, the Red River sand had more than 99.5 percent of the sand particles passing through the No. 4 sieve while more than 98.4 percent was retained on the No. 200 sieve $(75 \mu \mathrm{m})$. This well-distributed particle sized sand passes the Air Force ETL standard for sands placed on firing ranges (ETL 2002). The cost of delivery for the Red River sand was about \$6/yard cheaper than the competitor's sand. The metals concentrations associated with the Red River sand fell below or within the average range of digested values of the other sands evaluated during the sand selection process, except for antimony. Appendix A contains additional metals data for the different 
Table 6. Comparison of potential sands for the PRBerm $(n=3)$. Shading indicates values that are the optimum in selection criteria.

\begin{tabular}{|c|c|c|c|c|c|c|}
\hline Sand & $\begin{array}{l}\text { Moisture } \\
\text { Content } \\
\%\end{array}$ & $\begin{array}{l}\text { Retention }<\# 4 \\
\text { and }>\# 120 \\
\%\end{array}$ & $\begin{array}{l}\text { Angle of } \\
\text { Repose }\end{array}$ & $\begin{array}{l}\text { Cost } \\
\$ / y d\end{array}$ & $\begin{array}{l}\text { Background } \\
\text { Lead } \\
\mathrm{mg} / \mathrm{kg}\end{array}$ & $\begin{array}{l}\text { Background } \\
\text { Copper } \\
\mathrm{mg} / \mathrm{kg}\end{array}$ \\
\hline Red River $01^{1}$ & 4.4 & 95.2 & 32.4 & 11.25 & 9.96 & 1.80 \\
\hline Red River 02/03 & 3.7 & 96.6 & 32.2 & 11.25 & 9.96 & 1.80 \\
\hline $\begin{array}{l}\text { Tri-State Concrete } \\
01 / 02\end{array}$ & 3.7 & 95.2 & 32.6 & 17.20 & 6.39 & 1.81 \\
\hline Tri-State Mason 01/02 & 13.3 & 96.0 & 30.8 & 17.20 & 7.35 & 2.14 \\
\hline $\begin{array}{l}\text { Madden Screenings } \\
01 / 02\end{array}$ & 4.9 & 92.2 & 34.3 & n.d. & 15.80 & 15.08 \\
\hline Play Sand & n.d. ${ }^{2}$ & 99.9 & n.d. & $22.32^{3}$ & n.d. & n.d. \\
\hline \multicolumn{7}{|c|}{$\begin{array}{l}1 \text { Number refers to sample number; some samples have multiple numbers due to the sample location and } \\
\text { duplicates taken. } \\
2 \text { n.d. = not determined. } \\
3 \text { Based on purchase of } 50 \text { pound bags of play sand. }\end{array}$} \\
\hline
\end{tabular}

Table 7. Particle size distribution in potential PRBerm sands.

\begin{tabular}{|c|c|c|c|c|c|c|c|}
\hline \multirow[b]{2}{*}{ Sand ${ }^{1}$} & \multirow{2}{*}{$\begin{array}{l}\text { Retention } \\
<\# 4 \text { and } \\
>\# 120 \\
\%\end{array}$} & \multicolumn{6}{|c|}{ Particle Size - \% retained on the sieve } \\
\hline & & $\begin{array}{l}4.75 \mathrm{~mm} \\
\text { No. } 4\end{array}$ & $\begin{array}{l}850 \mathrm{~mm} \\
\text { No. } 20\end{array}$ & $\begin{array}{l}500 \mathrm{~mm} \\
\text { No. } 35\end{array}$ & $\begin{array}{l}250 \mathrm{~mm} \\
\text { No. } 60\end{array}$ & $\begin{array}{l}125 \mathrm{~mm} \\
\text { No. } 120\end{array}$ & $<125 \mathrm{~mm}$ \\
\hline Red River 01 & 95.2 & 0.7 & 10.1 & 22.9 & 47.7 & 14.5 & 4.1 \\
\hline Red River 02/03 & 96.6 & 0.9 & 26.5 & 23.8 & 37.6 & 8.7 & 2.5 \\
\hline $\begin{array}{l}\text { Tri-State Concrete } \\
01 / 02\end{array}$ & 95.2 & 3.8 & 36.6 & 25.4 & 22.7 & 10.6 & 1.0 \\
\hline $\begin{array}{l}\text { Tri-State Mason } \\
01 / 02\end{array}$ & 96.0 & 0.0 & 0.1 & 2.4 & 44.9 & 48.6 & 4.0 \\
\hline $\begin{array}{l}\text { Madden Screenings } \\
01 / 02\end{array}$ & 92.2 & 1.5 & 68.1 & 11.5 & 7.9 & 4.7 & 6.3 \\
\hline Play Sand & 99.9 & 0.0 & 6.4 & 34.3 & 51.6 & 7.6 & 0.1 \\
\hline
\end{tabular}


sands. Background soil concentrations of lead in the United States range from 7 to $20 \mathrm{mg} / \mathrm{kg}$ with an average of $10 \mathrm{mg} / \mathrm{kg}$ (Holmgren et al. 1993). The Red River sand falls well within the lead background levels of typical soils and sands.

Red River sand was obtained from a quarry within a 150-mile radius of Barksdale AFB. The sand was placed into a box (Figure 4) and M-16 rounds ( $0.223 \mathrm{cal}$ ) were fired into the sand to obtain a calculated lead concentration of $9,400 \mathrm{mg} / \mathrm{kg}$. The total digested lead concentration of the sand was $4,500 \pm 1,000 \mathrm{mg} / \mathrm{kg}$. In addition, several other metals $(\mathrm{Pb}, \mathrm{Cr}$, $\mathrm{Cu}, \mathrm{Ni}, \mathrm{Zn}, \mathrm{Fe}, \mathrm{Mn}, \mathrm{Mo}, \mathrm{V}$, and $\mathrm{Sb}$ ) were analyzed in the berm sand (Table 8). Several factors contribute to the difference in the calculated versus actual lead concentration in the post-fire on berm sand such as: rounds that were not retained within the catch box sand matrix, ricochets and skip-overs, rounds that penetrated the wood frame of the catch box, or rounds that were fired too high. In addition, some of the metals concentrations appear to have decreased from the initial concentrations, primarily due to the sample size and sample homogeneity used to determine the clean sand versus berm sand metals concentrations.

Table 8. Metal concentration in Red River sand pre- and post- lead enrichment.

\begin{tabular}{|l|l|l|l|l|}
\hline \multirow{2}{*}{$\begin{array}{l}\text { Metal } \\
\mathrm{mg} / \mathrm{kg}^{1}\end{array}$} & \multicolumn{2}{|c|}{ Clean Red River Sand } & \multicolumn{2}{c|}{ Berm Red River Sand } \\
\cline { 2 - 5 } & Avg $(\mathrm{n}=3)$ & Stdev & Avg $(\mathrm{n}=9)$ & Stdev \\
\hline Lead & 10.0 & 2.4 & 4549.1 & 1060.6 \\
\hline Chromium ${ }^{2}$ & 5.0 & 0.5 & 1.8 & 0.2 \\
\hline Copper & 1.8 & 0.1 & 137.1 & 63.6 \\
\hline Nickel & 2.2 & 0.1 & 1.3 & 0.1 \\
\hline Zinc & 5.0 & 1.0 & 12.6 & 5.1 \\
\hline Iron ${ }^{2}$ & $3,335.0$ & 227.1 & 1734.0 & 132.6 \\
\hline Manganese & 77.7 & 6.9 & 135.7 & 24.8 \\
\hline Molybdenum ${ }^{2}$ & 0.3 & 0.2 & 0.1 & $<0.1$ \\
\hline Vanadium ${ }^{2}$ & 6.9 & 0.8 & 3.1 & 0.3 \\
\hline $\begin{array}{l}\text { Antimony } \\
\text { 1 Outlier removed from average and standard deviation. } \\
\text { 2 Reduction of metals concentration is potentially due to samples size and soil } \\
\text { homogeneity. }\end{array}$ & 1.0 & 32.9 & 10.5 \\
\hline
\end{tabular}




\section{Amendment selection}

Six different amendments (Whole Bone Mechanical Apatite II, Crushed Bone Mechanical Apatite II, Buffer Block \#1, Buffer Block \#2, Buffer Block \#3, Buffer Block \#4) were evaluated in batch studies under different loading conditions and leaching procedures. Several factors were used to determine the appropriate amendment type and ratio used in the lysimeter studies:

- achieving the permit limits set for Barksdale AFB,

- achieving the TCLP lead permit limit of $5.0 \mathrm{mg} / \mathrm{L}$, and

- the ability of the amended soil to leach less metals (i.e., lead and copper) than the control soil.

\section{TCLP}

By comparing the metals concentrations remaining in solution after 18 hours of tumbling in the TCLP extraction solution against control soils with no amendments, the amended soils decreased the leaching of lead from 45 to 99 percent. All of the amended soils achieved or bettered the TCLP regulatory limit of $5 \mathrm{mg} / \mathrm{L}$ for lead leaching (Table 9). The lead TCLP concentrations had significant differences, based on the ANOVA F-Test, compared to the control for all of the amendments except for the 5 percent Buffer Block \#1, which was not statistically significant. A substantial decrease in the copper concentration was also noted in the TCLP solution ranging from 31 to greater than 71 percent, as compared to the unamended control leaching of copper.

As the amount of Crushed Bone Mechanical Apatite II increased in the soil, the reduction of metals leaching into the TCLP solution also increased. The 3, 5, and 10 percent Crushed Bone Mechanical Apatite II amendment decreased the TCLP lead concentration by greater than 90 percent, compared to the control. Of the four Buffer Block amendments, only Buffer Block \#4 reduced the TCLP lead concentration, compared to the control, by more than 90 percent. The difference in the copper TCLP concentrations was significant, based on the ANOVA F-Test, compared to the control for all of the amendments. 
Table 9. Results of the TCLP evaluation of amendments in SAFR berm soil. ${ }^{1}$

\begin{tabular}{|c|c|c|c|c|c|c|}
\hline \multirow[b]{2}{*}{ Amendment } & \multicolumn{2}{|c|}{ Lead, $\mathrm{mg} / \mathrm{L}$} & \multirow{2}{*}{$\begin{array}{l}\text { Reduction of } \\
\text { Leached Lead } \\
\text { Based on } \\
\text { Control } \\
\end{array}$} & \multicolumn{2}{|c|}{ Copper, mg/L } & \multirow{2}{*}{$\begin{array}{l}\text { Reduction of } \\
\text { Leached } \\
\text { Copper Based } \\
\text { on Control } \\
\end{array}$} \\
\hline & Avg, $n=3$ & Stdev & & Avg, $n=3$ & Stdev & \\
\hline Control - no amendment & 8.288 & 2.383 & n.a. ${ }^{2}$ & 0.176 & 0.068 & n.a. \\
\hline 1\% Crushed Bone Apatite II & 2.227 & 0.458 & 73.13 & 0.121 & 0.025 & 31.25 \\
\hline 3\% Crushed Bone Apatite II & 0.344 & 0.135 & 95.85 & 0.059 & 0.007 & 66.48 \\
\hline 5\% Crushed Bone Apatite II & 0.281 & 0.058 & 96.61 & 0.089 & 0.023 & 49.43 \\
\hline 10\% Crushed Bone Apatite II & $<0.064^{3}$ & 0.024 & $>99.23$ & $<0.051^{3}$ & 0.001 & $>71.02$ \\
\hline 5\% Buffer Block \#1 & 4.515 & 2.494 & 45.52 & $<0.094$ & 0.038 & $>46.59$ \\
\hline 5\% Buffer Block \#2 & 2.579 & 1.904 & 68.88 & $<0.059$ & 0.016 & $>66.48$ \\
\hline 5\% Buffer Block \#3 & 1.074 & 0.305 & 87.04 & $<0.050$ & n.a. & $>71.59$ \\
\hline 5\% Buffer Block \#4 & 0.699 & 0.130 & 91.57 & $<0.050$ & n.a. & $>71.59$ \\
\hline $\begin{array}{l}\text { 2.5\% Crushed Bone Apatite II } \\
\text { and 2.5\% Buffer Block \#4 }\end{array}$ & 0.196 & 0.058 & 97.63 & $<0.050$ & n.a. & $>71.59$ \\
\hline \multicolumn{7}{|c|}{$\begin{array}{l}1 \text { Lead initial concentration }=1,000 \mathrm{mg} / \mathrm{Kg} \text {. } \\
2 \text { n.a. }=\text { Not applicable. } \\
3 \text { Average includes RL of } 0.050 \mathrm{mg} / \mathrm{L} \text {. }\end{array}$} \\
\hline
\end{tabular}

\section{DDI S\&S}

While the Crushed Bone Mechanical Apatite II maintained a pH between the 6 and 9 permit limit, all of the Buffer Block amendments elevated the leachate $\mathrm{pH}$ above the permit limit of 9 (Table 10). The results from the DDI S\&S tests indicate that the Crushed Bone Mechanical Apatite II at 5 and 10 percent by weight reduced the lead concentration by 65 and 61 percent, respectively, while the 2.5 percent Apatite II and 2.5 percent Buffer Block Elixir \#4 reduced the lead concentration by greater than 80 percent. Buffer Block with Elixirs \# 3 and \#4 reduced the lead concentration compared to the control by greater than 78 and 69 percent, respectively. There was a significant difference in the lead DDI S\&S concentrations, based on the ANOVA F-Test, compared to the control for all of the amendments except for the 5 percent Buffer Block \#2, which was not statistically significant. The leaching of copper was not observed for any of the soil types under the DDI S\&S leaching procedure. 
Table 10. Results of the DDI S\&S evaluation of amended SAFR soil. ${ }^{1}$

\begin{tabular}{|c|c|c|c|c|c|}
\hline \multirow[b]{2}{*}{ Amendment } & \multirow[b]{2}{*}{$\mathrm{pH}$} & \multicolumn{2}{|c|}{ Lead, $\mathrm{mg} / \mathrm{L}$} & \multirow{2}{*}{$\begin{array}{l}\text { Reduction of } \\
\text { Leached Lead }{ }^{2} \\
\text { [Increase] } \\
\%\end{array}$} & \multirow{2}{*}{$\begin{array}{l}\text { Copper } \\
\mathrm{mg} / \mathrm{L}\end{array}$} \\
\hline & & Avg & Stdev & & \\
\hline $\begin{array}{l}\text { Control - no } \\
\text { amendment }\end{array}$ & 6.45 & 0.256 & 0.092 & n.a. ${ }^{3}$ & $<0.050^{4}$ \\
\hline $\begin{array}{l}\text { 1\% Crushed Bone } \\
\text { Apatite II }\end{array}$ & n.d. ${ }^{5}$ & 0.231 & 0.135 & 9.77 & $<0.050$ \\
\hline $\begin{array}{l}\text { 3\% Crushed Bone } \\
\text { Apatite II }\end{array}$ & n.d. & 0.399 & 0.140 & {$[35.84]$} & $<0.050$ \\
\hline $\begin{array}{l}\text { 5\% Crushed Bone } \\
\text { Apatite II }\end{array}$ & 6.86 & 0.089 & 0.041 & 65.23 & $<0.050$ \\
\hline $\begin{array}{l}10 \% \text { Crushed Bone } \\
\text { Apatite II }\end{array}$ & 6.98 & 0.098 & 0.045 & 61.72 & $<0.050$ \\
\hline 5\% Buffer Block \#1 & 10.41 & 0.168 & 0.044 & 34.38 & $<0.050$ \\
\hline 5\% Buffer Block \#2 & 10.59 & 0.199 & 0.087 & 22.27 & $<0.050$ \\
\hline 5\% Buffer Block \#3 & 10.86 & 0.055 & 0.001 & 78.52 & $<0.050$ \\
\hline 5\% Buffer Block \#4 & 10.87 & $<0.079$ & 0.048 & $>69.14$ & $<0.050$ \\
\hline $\begin{array}{l}\text { 2.5\% Crushed Bone } \\
\text { Apatite II and } 2.5 \% \\
\text { Buffer Block \#4 }\end{array}$ & 10.53 & $<0.050$ & n.a. & $>80.47$ & $<0.050$ \\
\hline \multicolumn{6}{|c|}{$\begin{array}{l}1 \text { Lead initial concentration }=1,000 \mathrm{mg} / \mathrm{Kg} \text {. } \\
2 \text { Based on concentration in control samples. } \\
3 \text { n.a. }=\text { not applicable. } \\
4 \text { Average includes RL value of } 0.050 \mathrm{mg} / \mathrm{L} \text {. } \\
5 \text { n.d. }=\text { not determined. }\end{array}$} \\
\hline
\end{tabular}

Because lead is an amphoteric metal, you would expect that the Buffer Block amendments producing a high $\mathrm{pH}$ solution would have higher lead concentrations. Since the DDI S\&S is a batch-scale experiment where the solution and amended soil are in contact for a limited time, the observed leaching effects of lead at the higher $\mathrm{pH}$ solution are limited, suggesting a need for a treatability study like the lysimeter cells as suggested by Tardy et al. (2003). 


\section{Three-day leaching}

The Whole Bone and Crushed Bone Mechanical Apatite II amendments provided suitable leachate $\mathrm{pH}$ from the 3-day leaching experiment, whereas all of the Buffer Block amendments elevated the leachate $\mathrm{pH}$ above the desired permit limit of 9 (Table 11). After 3 days of tumbling, the Whole Bone Mechanical Apatite II reduced the lead concentration in solution by only 35 percent; compared to the control. The Crushed Bone Mechanical Apatite II and Buffer Block \# 4 achieved greater than 81 and 86 percent lead reduction, respectively. Lead leaching was significantly different, based on the ANOVA F-Test, compared to the control for all of the amendments. The control and the Whole Bone Mechanical Apatite II leached copper, while the other amendments did not leach any reportable levels of copper. The 3-day leaching provided elevated lead concentrations and $\mathrm{pH}$ values that exceed the Barksdale AFB permit limits. These elevated concentrations also warranted the use of lysimeter studies to determine the effects of the amendments under more natural conditions prior to the field demonstration.

Table 11. Results of the 3-day leaching evaluation of amended berm soil. ${ }^{1}$

\begin{tabular}{|c|c|c|c|c|c|c|c|}
\hline \multirow[b]{2}{*}{ Amendment } & \multicolumn{2}{|c|}{$\mathrm{pH}$} & \multicolumn{2}{|c|}{$\begin{array}{c}\text { Leachate Lead } \\
\text { Concentration } \\
\mathrm{mg} / \mathrm{L}\end{array}$} & \multirow{2}{*}{$\begin{array}{l}\text { Lead } \\
\text { Reduction }{ }^{2} \\
\%\end{array}$} & \multicolumn{2}{|c|}{$\begin{array}{c}\text { Leachate Copper } \\
\text { Concentration } \\
\mathrm{mg} / \mathrm{L}\end{array}$} \\
\hline & Initial & 3-Day & Avg & Stdev & & Avg & Stdev \\
\hline $\begin{array}{l}\text { Control - no } \\
\text { amendment }\end{array}$ & 5.32 & 6.34 & 2.80 & 0.36 & n.a. ${ }^{3}$ & $<0.10^{4}$ & 0.02 \\
\hline $\begin{array}{l}\text { 5\% Whole Bone } \\
\text { Apatite II }\end{array}$ & 8.08 & 6.86 & 1.82 & 0.82 & 35.09 & $<0.09$ & 0.04 \\
\hline $\begin{array}{l}\text { 5\% Crushed Bone } \\
\text { Apatite II }\end{array}$ & 7.24 & 6.60 & 0.53 & 0.10 & 81.04 & $<0.05$ & n.a. \\
\hline 5\% Buffer Block \#4 & 10.99 & 11.49 & 0.38 & 0.08 & 86.47 & $<0.05$ & n.a. \\
\hline \multicolumn{8}{|c|}{$\begin{array}{l}{ }^{1} \text { Lead initial concentration }=1,000 \mathrm{mg} / \mathrm{kg} \text {. } \\
2 \text { Reduction based on control. } \\
{ }^{3} \text { n.a. }=\text { not applicable. } \\
{ }^{4} \text { Calculations include RL of } 0.050 \mathrm{mg} / \mathrm{L} \text {. }\end{array}$} \\
\hline
\end{tabular}

The amendment selection process narrowed down the six potential amendments to two, the Crushed Bone Apatite II and the Buffer Block \#4. The Crushed Bone Mechanical Apatite II at a 3, 5, and 10 percent loading decreased lead and copper leachate while maintaining an adequate 
leachate $\mathrm{pH}$. While the Buffer Block \#4 had an elevated $\mathrm{pH}$, it provided a significant decrease in lead and copper concentrations in the leachate as compared to the unamended control soil. The leaching studies help to determine specific parameters and capabilities of amendments, but they do not take into account long-term aging effects as the lysimeter studies do.

\section{Lysimeter Study I}

Bench-scale leaching tests indicated that Mechanical Apatite II and Buffer Block \#4 were suitable amendments to evaluate under a large-scale lysimeter study. The lysimeter cells using the Mechanical Apatite II amendment were terminated after four rain events due to elevated lead concentrations and odor associated with the lysimeter cells, while the study continued for the control and Buffer Block \#4 amended soils for a total of 16 rain events.

The 4-rain event average lead concentration as filtered and total metals exceeded the permit limit of $0.150 \mathrm{mg} / \mathrm{L}$ for the leachates (Table 12) and runoff (Table 13), excluding the filtered leachate control and the filtered runoff for the control and Buffer Block \#4 amended berm sand. The $\mathrm{pH}$ associated with the Buffer Block \# 4 leachate exceeded the Barksdale $\mathrm{pH}$ limit of 9, while the Apatite II amended soil produced a leachate $\mathrm{pH}$ that fell within the permit limit. The average runoff $\mathrm{pH}$ for the soils used in the lysimeter cells was within the permit limits. The DOC for the Apatite II amended leachates exceeded the Barksdale permit limit by at least 7 times, while the control and the Buffer Block \#4 amended berm sand were well below the DOC limit of $50 \mathrm{mg} / \mathrm{L}$.

Several factors may have increased the lead released in the Mechanical Apatite II and Buffer Block \#4 amended lysimeter cells. For the cells that were amended with the Mechanical Apatite II, there is the potential that the phosphate dissolution from the source was limited due to organic matter present on the Apatite II. In addition, this organic matter generated an increased biological activity within these lysimeter cells that was observed through the odor generated from the cells. The potential also exists for this biological activity to increase the solubility of metals. The organic matter may also decrease the nucleation site potential associated with the Apatite II. The Buffer Block \# 4 had an elevated $\mathrm{pH}$ that was the primary cause of the increased lead released from this cell. 
Table 12. Lysimeter cell leachate. Shading indicates values that meet selection criteria outlined in the objectives.

\begin{tabular}{|l|l|l|l|l|l|l|}
\hline \multirow{2}{*}{ Amendment } & \multicolumn{2}{|c|}{$\begin{array}{c}\text { Avg. Lead, mg/L } \\
(\mathrm{n}=4)\end{array}$} & \multicolumn{2}{c|}{$\begin{array}{c}\text { Avg. Copper, } \mathrm{mg} / \mathrm{L} \\
(\mathrm{n}=4)\end{array}$} & $\begin{array}{l}\mathrm{DOC} \\
\mathrm{mg} / \mathrm{L} \\
(\mathrm{n}=2)\end{array}$ & $\begin{array}{l}\mathrm{pH} \\
(\mathrm{n}=2)\end{array}$ \\
\cline { 2 - 8 } & Filtered & Total & Filtered & Total & 50 & $6-9$ \\
\hline Barksdale AFB Permit Limit & 0.150 & & 0.500 & & $6.91^{2}$ \\
\hline Control - No Amendment & $<0.050^{1}$ & 0.387 & $<0.050$ & $<0.050$ & 2 & 6.88 \\
\hline $3 \%$ Mechanical Apatite II & 0.646 & 2.031 & 0.319 & 0.988 & 347 & 6.74 \\
\hline $5 \%$ Mechanical Apatite II & 1.008 & 3.143 & 0.621 & 1.650 & 934 & 6.55 \\
\hline 8\% Mechanical Apatite II & 0.488 & 2.050 & 0.525 & 1.873 & 1739 & 10.67 \\
\hline 4.5\% Buffer Block \#4 & 0.825 & 3.231 & $<0.050$ & 0.051 & 8 & \\
\hline $\begin{array}{l}1 \\
\text { 2 RL was set at 0.050 mg/L. }\end{array}$ The average leachate pH for the control soil elevated to 8.21 by the end of 16 rain events. \\
\hline
\end{tabular}

Table 13. Lysimeter cell runoff. Shading indicates values that meet selection criteria outlined in the objectives.

\begin{tabular}{|c|c|c|c|c|c|c|}
\hline \multirow[b]{2}{*}{ Amendment } & \multicolumn{2}{|c|}{$\begin{array}{l}\text { Avg. Lead, } \mathrm{mg} / \mathrm{L} \\
(\mathrm{n}=4)\end{array}$} & \multicolumn{2}{|c|}{$\begin{array}{l}\text { Avg. Copper, } \mathrm{mg} / \mathrm{L} \\
(\mathrm{n}=4)\end{array}$} & \multirow{2}{*}{$\begin{array}{l}\mathrm{DOC} \\
\mathrm{mg} / \mathrm{L} \\
(\mathrm{n}=2)\end{array}$} & \multirow{2}{*}{$\begin{array}{l}\mathrm{pH} \\
(\mathrm{n}=4)\end{array}$} \\
\hline & Filtered & Total & Filtered & Total & & \\
\hline Barksdale AFB Permit Limit & \multicolumn{2}{|l|}{0.150} & \multicolumn{2}{|l|}{0.500} & 50 & $6-9$ \\
\hline Control - No Amendment & 0.144 & 6.022 & $<0.050^{1}$ & 0.101 & n.d. ${ }^{2}$ & $6.63^{3}$ \\
\hline 3\% Mechanical Apatite II & 0.087 & 7.652 & 0.057 & 0.254 & n.d. & 6.80 \\
\hline 5\% Mechanical Apatite II & 0.231 & 7.466 & 0.090 & 0.300 & n.d. & 6.82 \\
\hline 8\% Mechanical Apatite II & 0.406 & 8.036 & 0.135 & 0.340 & n.d. & 6.48 \\
\hline 4.5\% Buffer Block \#4 & 0.053 & 5.768 & $<0.050$ & 0.090 & n.d. & 8.34 \\
\hline $\begin{array}{l}1 \mathrm{RL} \text { was set at } 0.050 \mathrm{mg} / \mathrm{L} \\
2 \mathrm{n} . \mathrm{d} .=\text { not determined. }\end{array}$ & & & & & & \\
\hline
\end{tabular}

Elevated DOC (Table 12) was observed in the Mechanical Apatite II amended sand leachate and is shown for rain event \#3 in Figure 6. In addition, the Mechanical Apatite II amended berm sand produced an offensive odor. Additional batch-scale (aging) studies were conducted to determine the effects of biological growth on Apatite II and the use of another formulated Buffer Block. Buffer Block \#4 provided the required formulation to decrease the lead mobility, but also increased the solution $\mathrm{pH}$, so Buffer Block \#4 was carbonated to create Buffer Block \#5. 


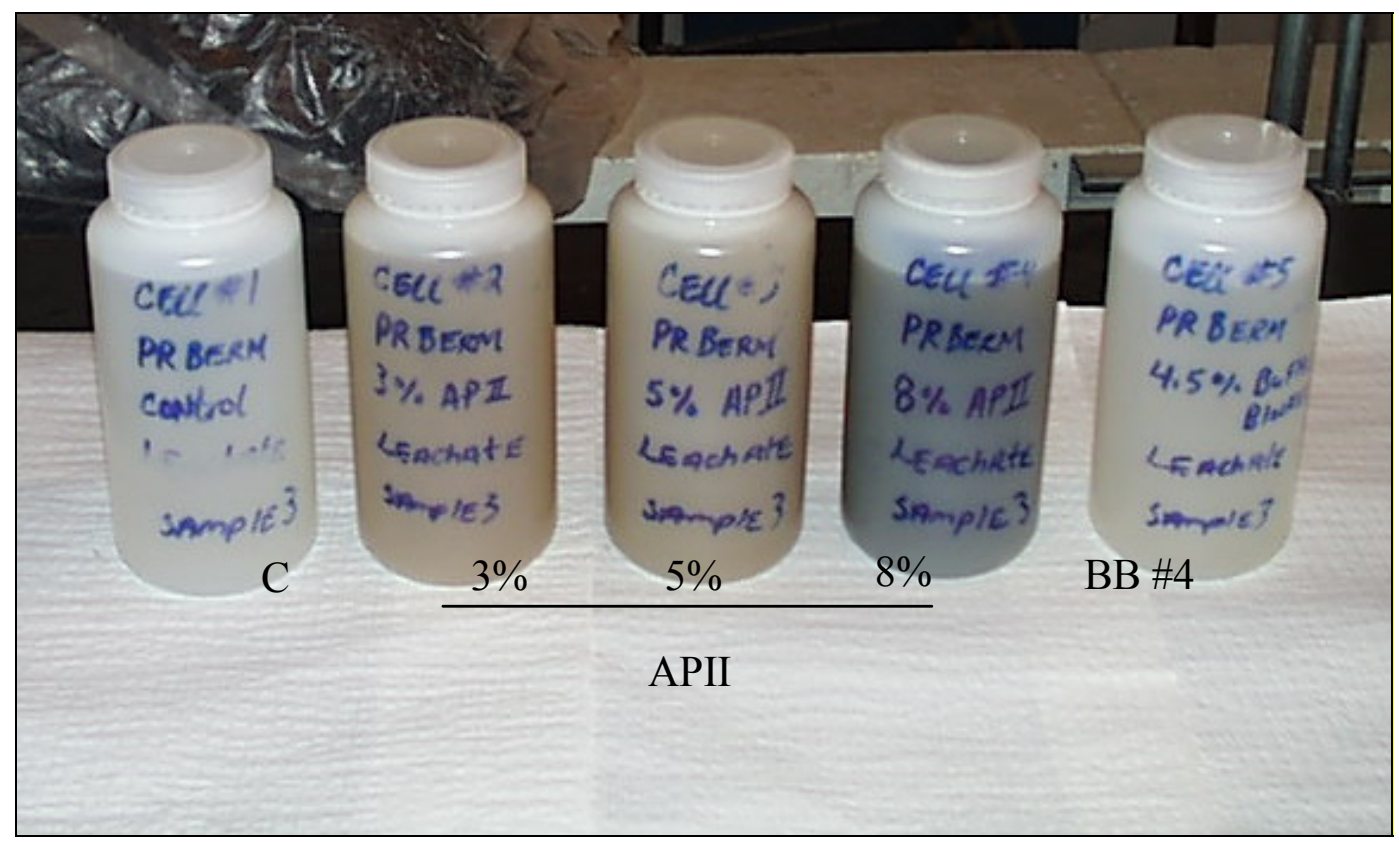

Figure 6. Leachate from rain event \#3, notice the dark color associated with the Apatite II (center three-APII) as compared to the control (C) and Buffer Block \#4 (BB\#4) leachates.

This new Buffer Block \# 5 provided the correct chemical formulation with the desired lower $\mathrm{pH}$ and was used in Lysimeter Study II. The results from Lysimeter Study I and the batch-scale experiments were used to design the second lysimeter study.

\section{Aged amendment study}

Mechanical and Enzymatic Apatite II contain approximately 35 percent organics by weight, and thus contain many of the micronutrient, macronutrients, and substrate required for biological growth. Mechanical Apatite II was heated at approximately $475^{\circ} \mathrm{C}$ in order to create a clean, organic matter free, Baked Apatite II that could be used to determine the aging effects, or biological activity effects, of the Apatite II source. The average percent moisture content for the Mechanical and Baked Apatite II was determined to be approximately 58 and 57 percent, respectively, after being agitated for 10 minutes and then soaked in water for an additional 2 hours.

\section{Stirred sorption study}

The stirred sorption study results indicate a lead reduction limiting effect was caused by either the organics or the biological growth associated with the Apatite II. After Day 10 of the stirred sorption experiment, the results 
indicate that the aged Mechanical Apatite II has similar results to Day o (Table 14), with a greater than 70 percent lead reduction. The overall soluble lead reduction for the aged Mechanical Apatite II ranged from 28 to 95 percent. The aged Baked Apatite II maintained a greater than 91 percent reduction of the soluble lead throughout the 17-day aging period, with a soluble lead reduction range from 91 to 96 percent. Heating the Mechanical Apatite II to create Baked Apatite II removed a majority of the organic substrate material that is critical to the generation of biological growth and nucleation site interference. The Baked Apatite II provides a readily available amendment that is not limited by physical and chemical barriers associated with soluble lead reduction.

Table 14. Reduction of lead during the stirred sorption study of aged Mechanical Apatite II and Baked Apatite II.

\begin{tabular}{|c|c|c|c|c|c|}
\hline \multirow[b]{2}{*}{ Sample } & \multirow[b]{2}{*}{ Aging Day } & \multicolumn{3}{|c|}{ Sample Time Avg. Lead Conc., mg/L $(n=3)$} & \multirow{2}{*}{$\begin{array}{l}\text { Reduction }{ }^{2} \\
\%\end{array}$} \\
\hline & & Initial & 15 Minutes $^{1}$ & 30 Minutes $^{1}$ & \\
\hline \multirow{5}{*}{$\begin{array}{l}\text { Mechanical } \\
\text { Apatite II }\end{array}$} & $0^{3}$ & 45.03 & 13.27 & 12.03 & 73 \\
\hline & 3 & 45.58 & 23.80 & 24.37 & 47 \\
\hline & 6 & 51.07 & 37.28 & 36.36 & 29 \\
\hline & 10 & 48.14 & 3.21 & 1.94 & 96 \\
\hline & 17 & 45.27 & 5.12 & 4.14 & 91 \\
\hline \multirow{5}{*}{ Baked Apatite II } & $0^{3}$ & 45.03 & 2.39 & 3.72 & 92 \\
\hline & 3 & 45.58 & 1.52 & 2.91 & 94 \\
\hline & 6 & 51.07 & 4.50 & 2.66 & 95 \\
\hline & 10 & 48.14 & 4.13 & 2.57 & 95 \\
\hline & 17 & 45.27 & 0.55 & 1.53 & 97 \\
\hline \multicolumn{6}{|c|}{$\begin{array}{l}1 \text { No significant change in soluble lead concentration after } 15 \text { minutes of stirring. } \\
2 \text { Percent reduction based on initial and } 30 \text { minute lead }(\mathrm{Pb}) \text { concentrations. } \\
3 \text { Day } 0 \text { media were soaked in reagent grade water for } 1 \text { hour prior to the sorption study. }\end{array}$} \\
\hline
\end{tabular}

Apatite II is known to have buffering capacity by releasing $\mathrm{PO}_{43}-$, OH-, and substituted $\mathrm{CO}_{32}$ - groups that will maintain a system's runoff or leachate $\mathrm{pH}$ between 6.5 and 7 (Wright et al. 2004). During the stirred sorption experiments, the initial $50 \mathrm{mg} / \mathrm{L}$ lead solution averaged a $\mathrm{pH}$ of 5.1 (Appendix A). As the Mechanical Apatite II aged in the stirred sorption studies, a pH between 6.5 and 7.5 was maintained. The aged Baked Apatite II maintained a pH between 8.0 and 9.5. 


\section{Semi-static sorption study}

Results from the semi-static sorption study indicate similar trends as the stirred sorption study. At Day 10 of sampling, the aged Mechanical Apatite II had greater than 98 percent lead reduction (Figure 7). The biological growth associated with the Mechanical Apatite II has potentially entered the stationary (or death) phase (where substrate for growth is not available) allowing for physical and chemical reduction of soluble lead in solution. Between Day 3 and Day 6 of aging, the biological growth has potentially achieved maximum growth and entered the exponential growth phase, producing greater DOC and associated organic matter. After the initial 18-hour settling period, the samples remained static for an additional 15 days. During these 15 days, the soluble lead reduction for the Mechanical and Baked Apatite II achieved greater than 98 percent reduction of the soluble lead (Appendix A).

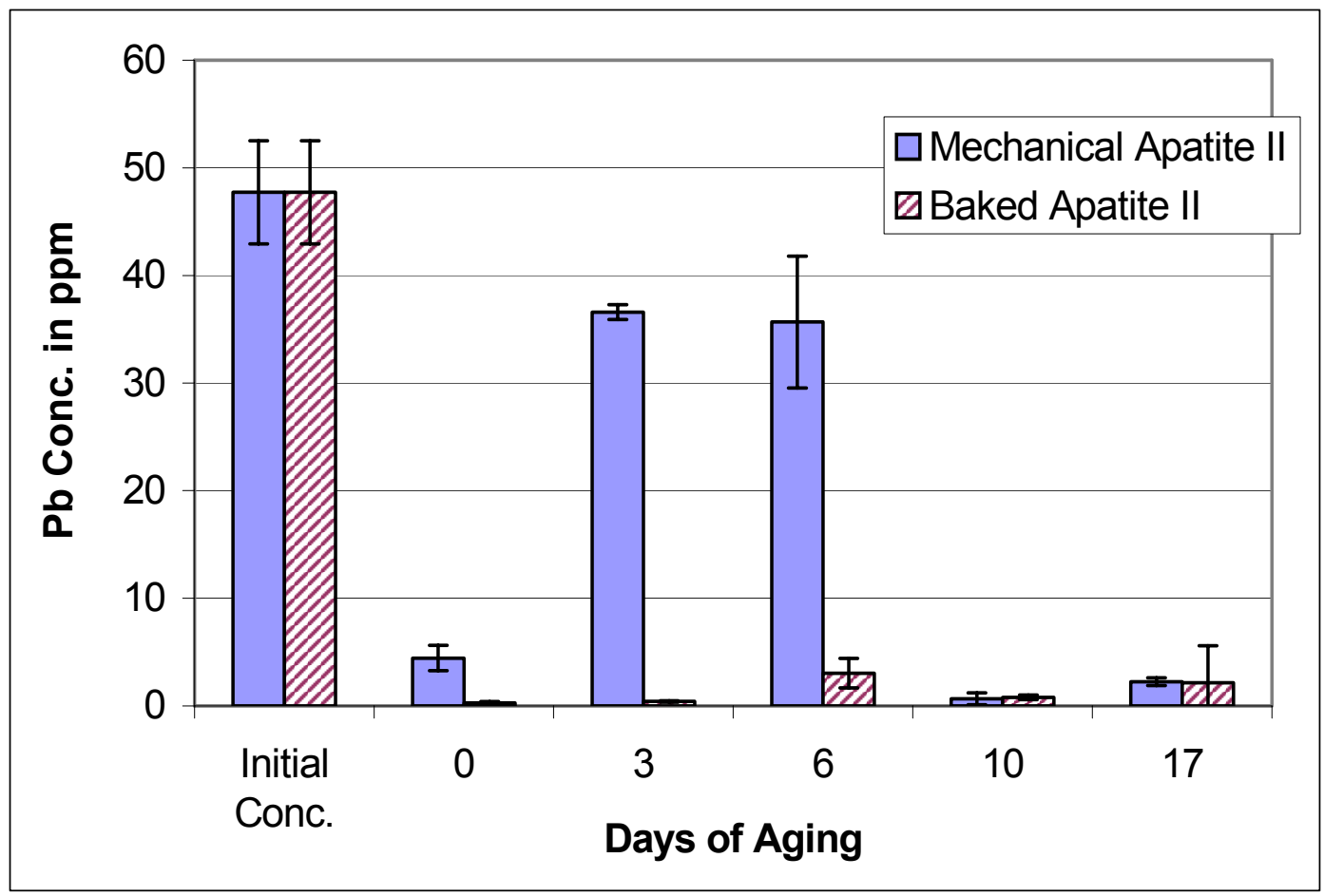

Figure 7. Comparison of lead concentration of Mechanical and Baked Apatite II from the semi-static sorption studies. After Day 6, the aged Mechanical Apatite II performed similar to the aged Baked Apatite II.

\section{Static sorption study}

A static sorption study was conducted to determine if the agitation of the stirred sorption and shaken semi-static sorption studies had any effects on the sorption of the aged Mechanical and Baked Apatite II. The general 
thought was that the agitation allowed the organics and biofilm to slough off the Mechanical Apatite II, thus promoting soluble phosphorous release and increasing the available nucleation sites. In the static sorption experiments, mechanically and enzymatically produced Apatite II and Baked Apatite II were compared.

Soluble lead reduction for the aged mechanically and enzymatically produced Apatite II (Figure 8) averaged 50 and 57 percent, respectively, during the first 6 days of aging, while the Baked Apatite II averaged greater than 99 percent soluble lead reduction. At the seventh day of aging, soluble lead reduction increased dramatically for the mechanically and enzymatically produced Apatite II. The Baked Apatite II averaged greater than 99 percent soluble lead reduction throughout the 17-day static sorption study.

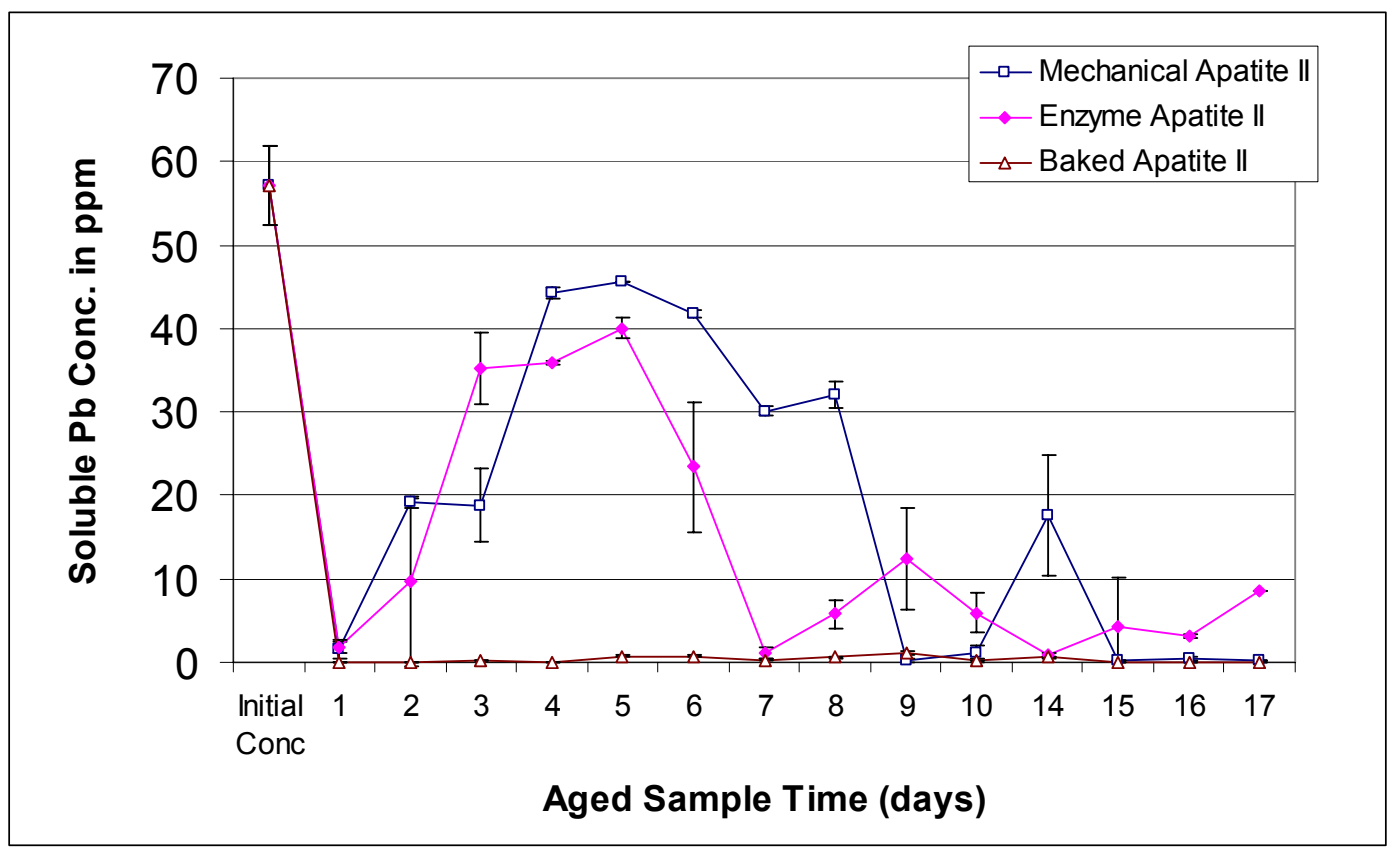

Figure 8. Soluble lead concentration in solution after 18-hour static sorption experiments using aged Apatite II.

While there was a significant decrease in the soluble lead concentration due to the addition of Apatite II amendments, the digested solution contained much greater lead concentration levels (Figure 9). The mechanically and enzymatically produced Apatite II averaged total lead concentrations in solution of 37 and $38 \mathrm{mg} / \mathrm{L}$, respectively. The Baked Apatite II 


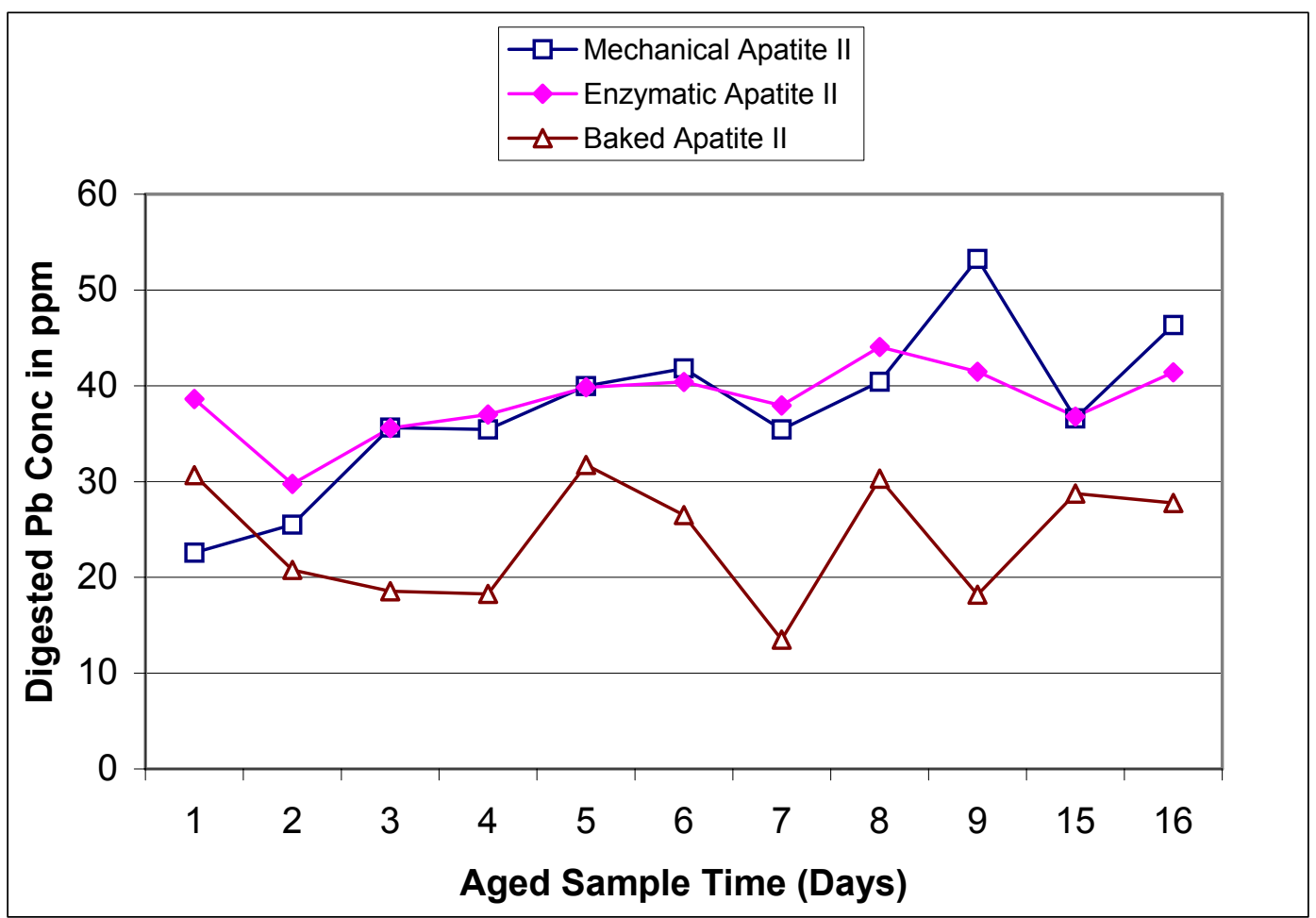

Figure 9. Total (digested liquid) lead concentration in solution after 18-hour static sorption experiments using aged Apatite II material.

performed slightly better, with an average total lead concentration in solution of $24 \mathrm{mg} / \mathrm{L}$. The high concentration of lead in the digested solution indicates that, although the lead is reacting with the phosphate and potential organic matter within the Apatite II amended solutions, a significant amount of lead is not precipitating out. The low degree of precipitation is hypothesized to be due to small colloidal particles that are suspected to have formed. These particles are a potential route whereby soluble (or colloidal) forms of lead could become mobile, reducing the overall effectiveness of the amendment. Therefore, further investigation is necessary in order to understand the lead mobility and aging properties of the Apatite II amendments.

\section{Dissolved organic carbon of aged Apatite II sources}

The aging of mechanically and enzymatically produced Apatite II created substantially more DOC than the aging of Baked Apatite II (Figure 10). Samples were taken from the aged Apatite II solutions over a 17-day period. During the first 2 days, little DOC was present in the solutions. At Day 3 the increase in the DOC present in the aged mechanically and enzymatically produced Apatite II was substantial. The aged Baked 


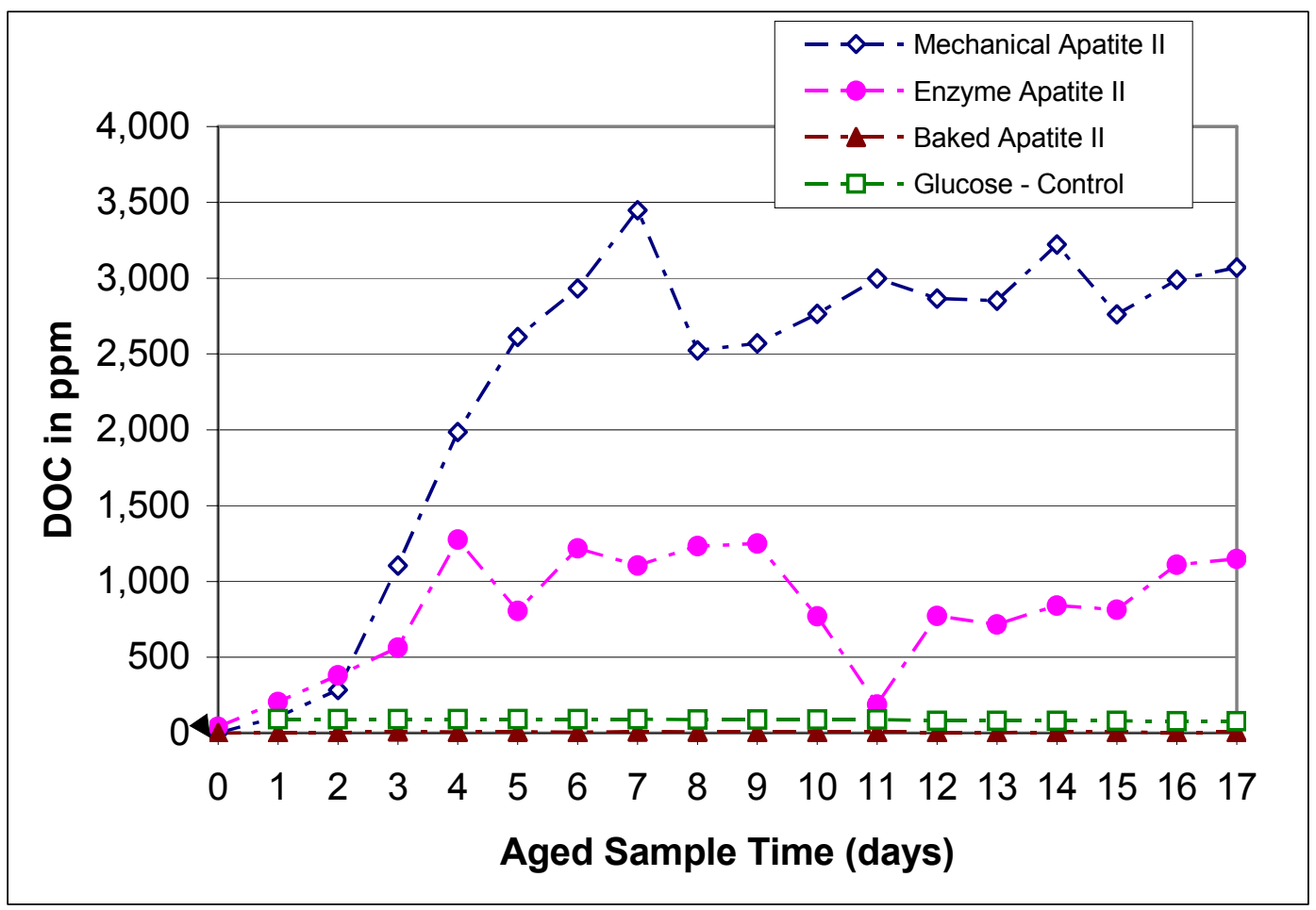

Figure 10. Daily DOC $(<0.45 \mu \mathrm{m})$ from the aging solution of the Apatite II sources.

Apatite II averaged a DOC concentration of less than $10 \mathrm{mg} / \mathrm{L}$. This level is due to the high temperature (approximately $475{ }^{\circ} \mathrm{C}$ ) at which the Mechanical Apatite II was baked, where the majority of the organics were removed.

It is worth noting that the DOC concentration profile follows the typical cell growth cycle curve of an initial lag phase, in this case between Day o and Day 2. Between Day 3 and Day 7, an exponential DOC production occurs that mimics exponential cell growth. Between Day 7 and Day 17, a plateau of DOC concentration is reached that is similar to the stationary cell growth phase. After comparing the lead concentration and DOC levels in Table 14 and Figures 7, 8, and 10, there is a direct correlation between the exponential increase in DOC concentration and the ability of the amendment to reduce the soluble lead concentration in solution.

\section{Column study}

The column study was conducted in two phases. Phase I provided constant saturation of the column media by having two wetting events per day. During the constant saturation, a significant amount of lead left the Apatite II amended cells (Figure 11 and 12) and significant amounts of copper left the 


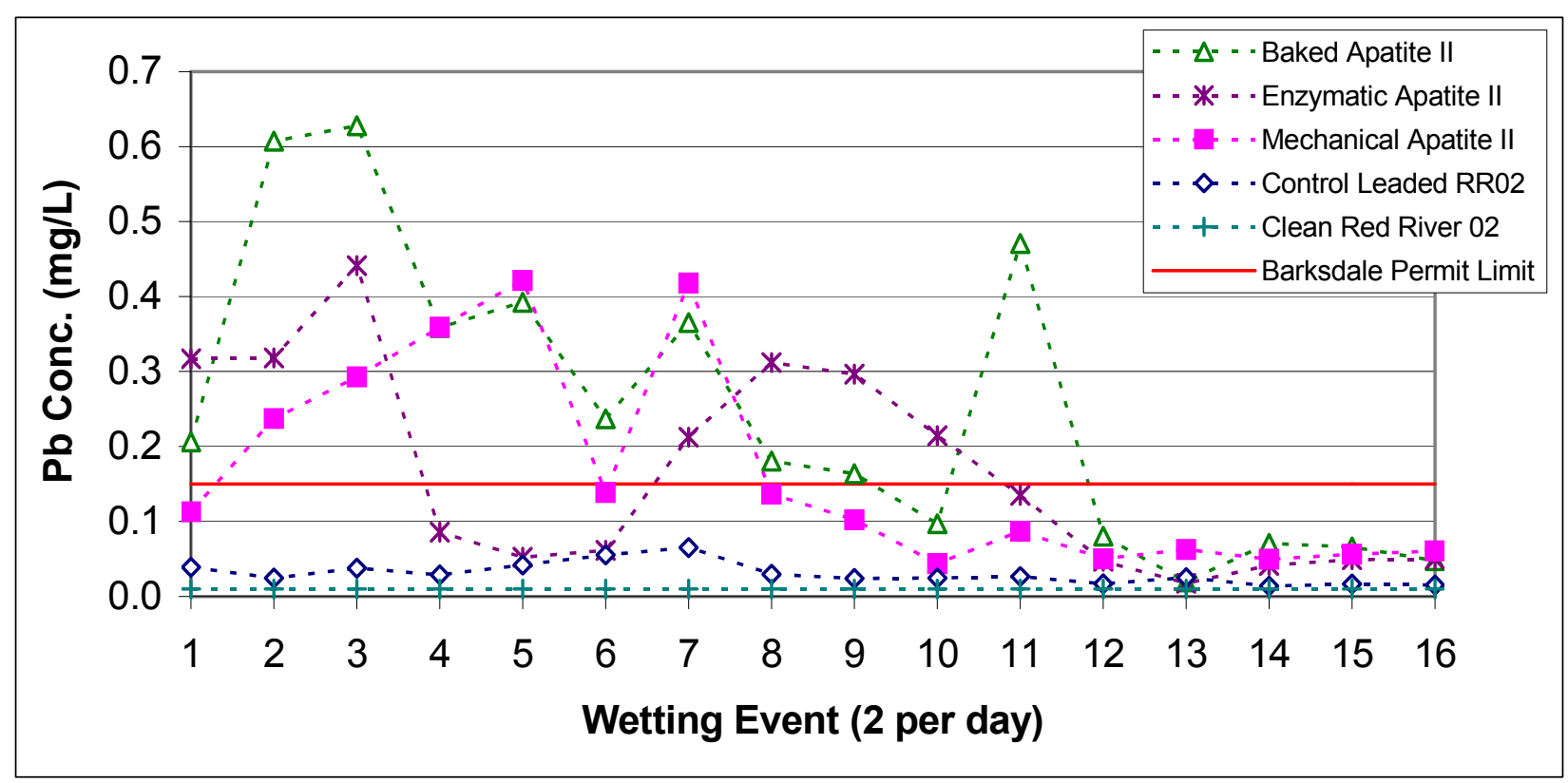

Figure 11. Soluble lead concentration for the Apatite II amendments in leachate during Phase I of the column study.

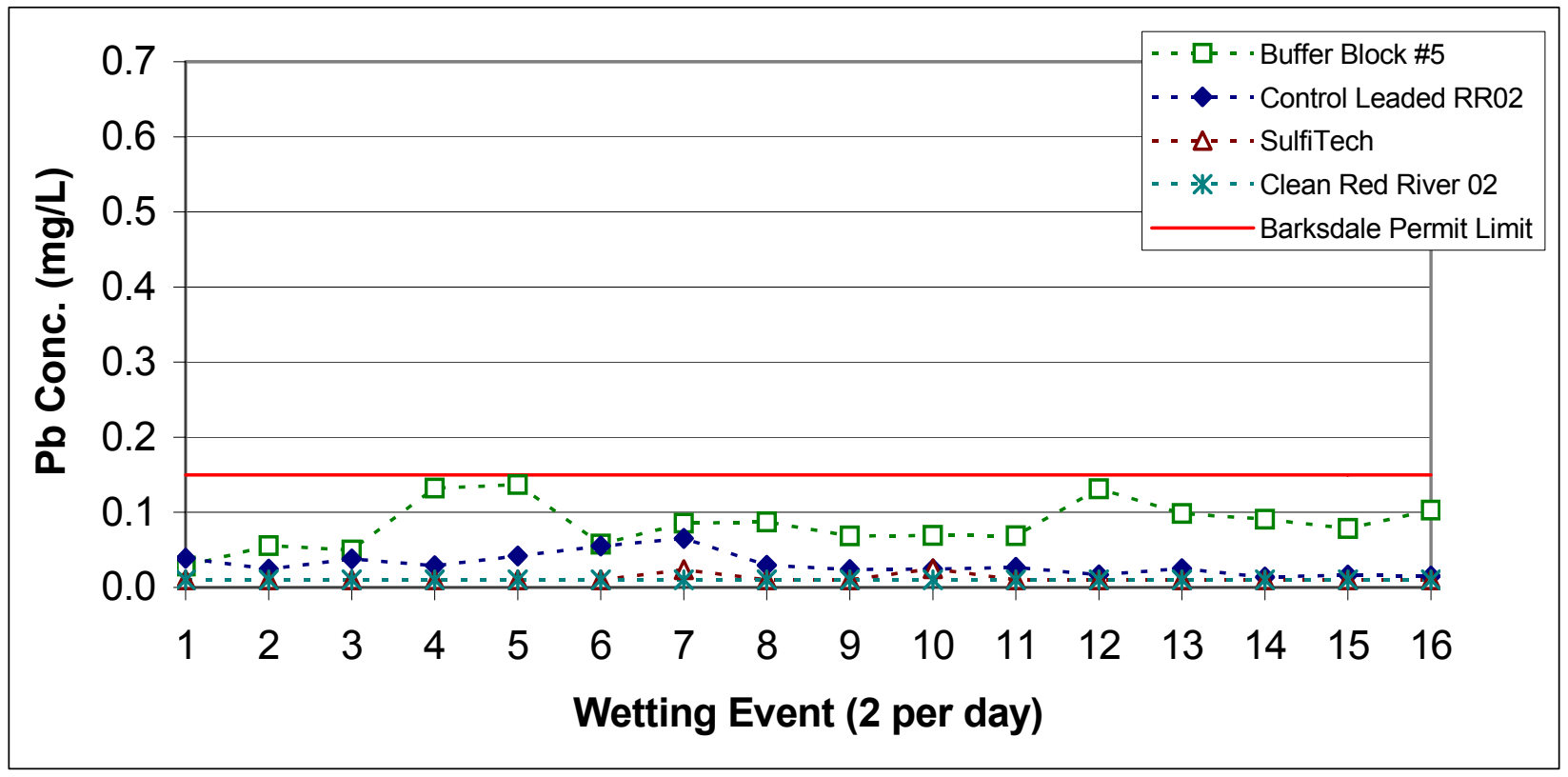

Figure 12. Soluble lead concentration in leachate for the Buffer Block \#5 and SulfiTech amendments during Phase I of the column study.

mechanically and enzymatically produced Apatite II amended columns (Appendix A). Buffer Block \#5, with the same chemical formulation as Buffer Block \# 4 but with a lower buffering $\mathrm{pH}$, was used in the column study prior to use in Lysimeter Study II. The soluble lead concentration found in the other columns was maintained below the permit limit of $0.150 \mathrm{mg} / \mathrm{L}$. 
Phase II was an intermittent saturation column study allowing for wetting and drying cycles between additions of water, with only one wetting event per week. While the leaching concentrations were similar for the saturated and intermittent column studies, significant soluble lead and copper concentrations (Appendix A) left the mechanically and enzymatically produced Apatite II amended columns during the first five wetting events.

Correlation between aging effects of the Apatite II and the release of lead and copper in the leachate was strong as was observed in the first lysimeter study, the aged amendment study, and the column study. When the column was allowed to remain saturated, overall release of lead in the leachate from all of the columns was increased compared to the columns that were allowed to have wetting and drying cycles (Figure 13). For the mechanically and enzymatically produced Apatite II amended columns, the total amount of lead released during the two phases of the column study were similar, but for the other columns, significantly less lead was released when the columns were allowed to follow a wetting and drying cycle that mimics more natural conditions. This result is particularly evident with the Baked Apatite II and 5 percent Buffer Block \#5 amended columns, suggesting the need to examine the soils under more natural conditions such as in the lysimeter cells.

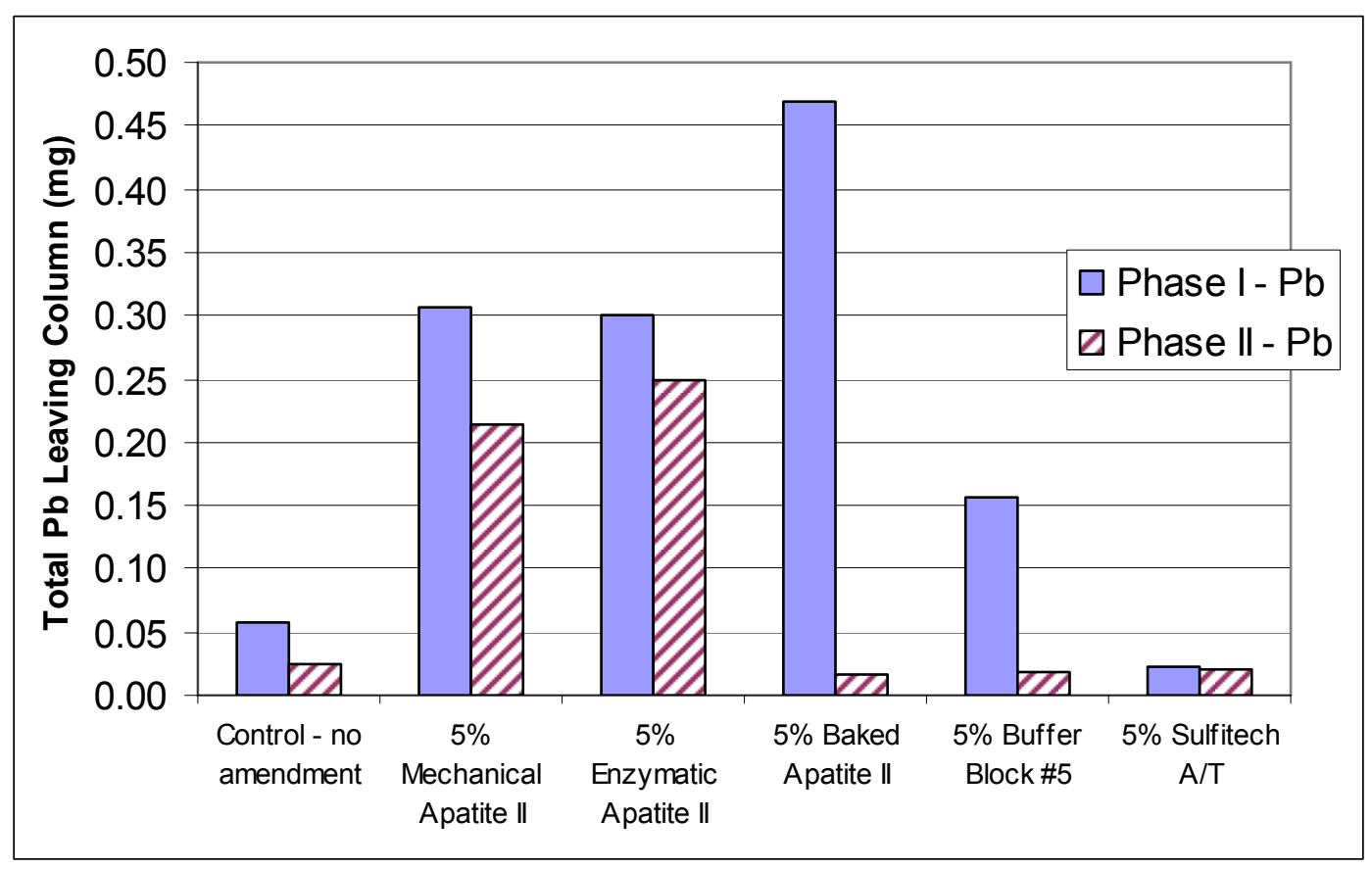

Figure 13. Total soluble lead leaving the column by phase. 
Understandably, since the same columns were used for both saturated and intermittent studies, the possibility exists that the soluble lead was released or flushed out of the columns during the saturated column study. However, such an explanation does not account for the substantial difference in the amount of lead released for the mechanically and enzymatically produced Apatite II versus the Baked Apatite II and the Buffer Block \#5 when the total lead released is compared for both column studies (Figure 13). Additional column studies, or a larger volume of berm material within the lysimeters, may help differentiate an amendments potential under similar conditions.

As drying occurs, on the molecular level, there is an increased concentration effect of soluble amendment to react with soluble metals (i.e., $\mathrm{Pb}^{2+}$ ). Therefore, chances are better for them to collide in solution and stabilize in the form of a precipitate. Furthermore, when the inert columns have a decreased concentration of DOC (i.e., organics, humics, etc.), chances are better for soluble metals to react with the amendment by reducing the competition with organics, humics, etc.

The column study results were used in the design considerations of amendment type and amount used in the second lysimeter study. For continuity purposes, all of the amendments used in the column study were selected for use in the second lysimeter study.

\section{Lysimeter Study II}

After conducting the aged amendment and column studies, the use of Apatite II as an amendment in the PRBerm was less likely due to increased lead, copper, and DOC concentrations. To validate this conclusion, a second lysimeter study was conducted using the Apatite II amendments along with a newly formulated Buffer Block amendment and a sulfurbased amendment. Results from the second lysimeter cell study indicate that the Apatite II performed as expected with increased TSS (Figure 14), DOC (Figure 15), and metals concentrations leaving the cell as leachate.

Pre- and post-TCLP and DDI S\&S leaching tests were conducted on the amended berm sand. The Apatite II amended berm sand leached less lead during the post-TCLP than the unamended, SulfiTech, and Buffer Block amended berm sands (Table 15). The lead sulfite (Scotlandite) may be 

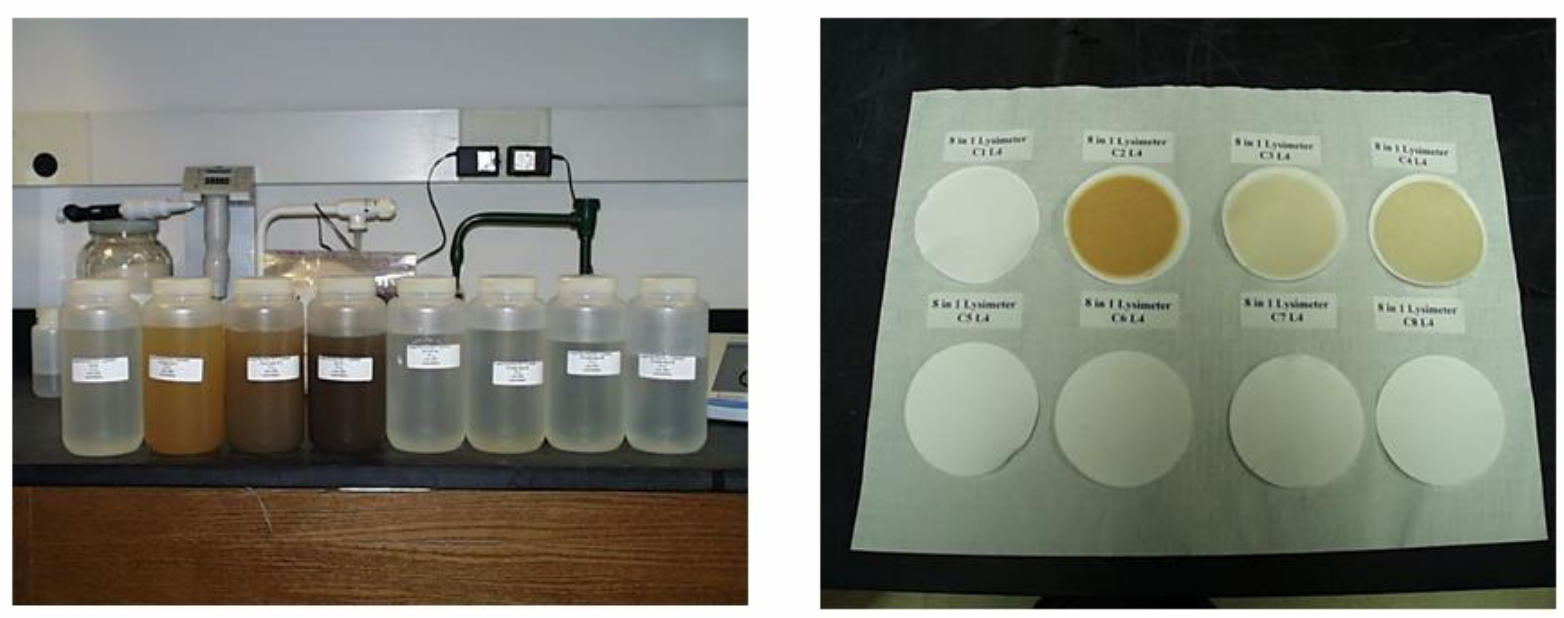

Figure 14. Leachate (left) and TSS filters (right) from rain event \#4. Apatite II amendments show significant color (left picture: $2^{\text {nd }}, 3^{\text {rd }}, 4^{\text {th }}$ bottles) and residue in leachate and on filter paper (right picture: top row, three filters on right).

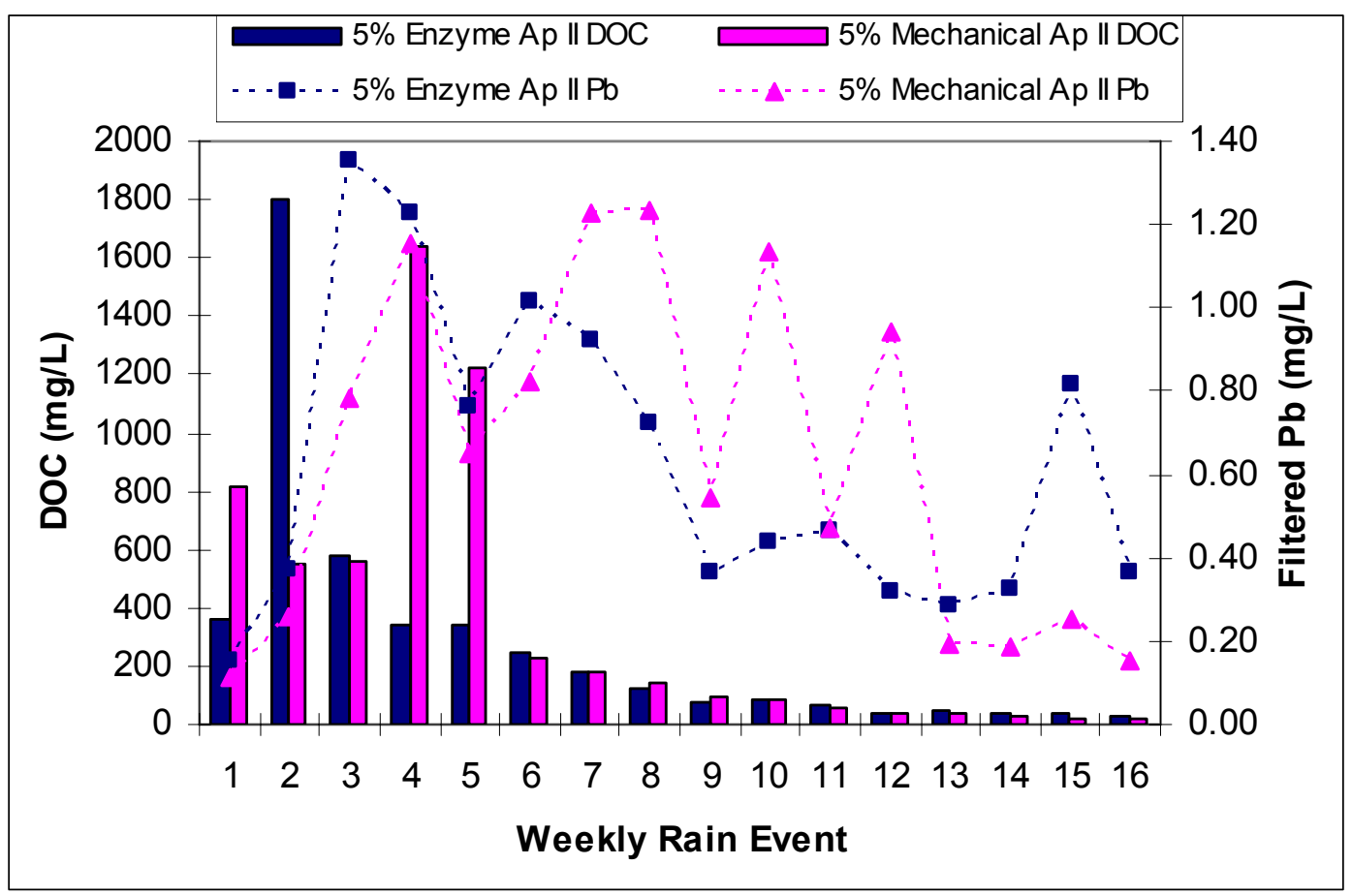

Figure 15. Enzyme and Mechanical Apatite II DOC and filtered lead concentrations in Lysimeter Study II. 
Table 15. Lysimeter Study II pre- and post-amendment berm sand lead TCLP and DDI S\&S average values. Shading indicates values that meet selection criteria outlined in the objectives.

\begin{tabular}{|c|c|c|c|c|c|}
\hline \multirow[b]{2}{*}{ Amendment } & \multicolumn{2}{|c|}{$\begin{array}{c}\text { Pre-TCLP Lead } \\
\mathrm{mg} / \mathrm{L}\end{array}$} & \multicolumn{2}{|c|}{$\begin{array}{c}\text { Post-TCLP Lead } \\
\mathrm{mg} / \mathrm{L}\end{array}$} & \multirow{2}{*}{$\begin{array}{l}\text { \% Reduction } \\
\text { [Increase] }\end{array}$} \\
\hline & $\operatorname{Avg}(n=3)$ & Stdev & $\operatorname{Avg}(n=3)$ & Stdev & \\
\hline Unamended Sand & 120.63 & 52.36 & 64.59 & 15.75 & 46.46 \\
\hline 5\% Baked Apatite II & 1.44 & 0.36 & 0.57 & 0.28 & 60.75 \\
\hline 5\% Enzymatic Apatite II & 32.02 & 37.36 & 0.38 & 0.40 & 98.82 \\
\hline 5\% Mechanical Apatite II & 2.21 & 1.41 & 0.59 & 0.20 & 73.48 \\
\hline $5 \%$ SulfiTech & 0.07 & 0.03 & 51.70 & 6.54 & [99.86] \\
\hline 1\% Buffer Block \#5 & 175.60 & 26.54 & 53.80 & 5.84 & 69.36 \\
\hline 3\% Buffer Block \#5 & 51.21 & 9.05 & 64.09 & 5.94 & [20.10] \\
\hline \multirow[t]{3}{*}{ 5\% Buffer Block \#5 } & 150.47 & 36.27 & 67.22 & 12.83 & 55.32 \\
\hline & \multicolumn{2}{|c|}{$\begin{array}{c}\text { Pre-DDI S\&S Lead } \\
\text { mg/L }\end{array}$} & \multicolumn{2}{|c|}{$\begin{array}{c}\text { Post-DDI S\&S Lead } \\
\mathrm{mg} / \mathrm{L}\end{array}$} & \multirow{2}{*}{$\begin{array}{l}\text { \% Reduction } \\
\text { [Increase] }\end{array}$} \\
\hline & Avg $(n=3)$ & Stdev & $\operatorname{Avg}(n=3)$ & Stdev & \\
\hline Unamended Sand & 0.10 & 0.02 & 0.21 & 0.14 & [52.38] \\
\hline 5\% Baked Apatite II & 0.13 & 0.01 & 0.17 & 0.04 & 3.00 \\
\hline 5\% Enzymatic Apatite II & 0.26 & 0.13 & 0.72 & 0.20 & [63.89] \\
\hline 5\% Mechanical Apatite II & 0.29 & 0.17 & 0.46 & 0.08 & [36.95] \\
\hline $5 \%$ SulfiTech & 0.03 & 0.01 & 0.02 & 0.01 & 44.39 \\
\hline 1\% Buffer Block \#5 & 0.10 & 0.02 & 0.30 & 0.02 & [66.67] \\
\hline 3\% Buffer Block \#5 & 0.04 & 0.01 & 0.05 & 0.01 & [20.00] \\
\hline 5\% Buffer Block \#5 & 0.06 & 0.01 & 0.20 & 0.03 & [70.00] \\
\hline
\end{tabular}

oxidizing to form lead sulfate (potentially more soluble than lead sulfite) and thus may explain the increase in lead released during TCLP; additional lab work needs to be conducted in order to verify the results. There was generally an increase in the lead leached during the DDI S\&S procedure for all of the amended berm sands except for the Baked Apatite II and SulfiTech amended berm sands. Copper released during the postTCLP for the Apatite II amended berm sands also increased (Table 16), and, for the same amendments under the DDI S\&S procedure, a slight increase occurred. 
Table 16. Lysimeter Study II pre- and post-amendment berm sand copper TCLP and DDI S\&S average values.

\begin{tabular}{|c|c|c|c|c|c|}
\hline \multirow[b]{2}{*}{ Amendment } & \multicolumn{2}{|c|}{$\begin{array}{c}\text { Pre-TCLP Copper } \\
\text { mg/L }\end{array}$} & \multicolumn{2}{|c|}{$\begin{array}{c}\text { Post-TCLP Copper } \\
\mathrm{mg} / \mathrm{L}\end{array}$} & \multirow[b]{2}{*}{$\begin{array}{l}\text { \% Reduction } \\
\text { [Increase] }\end{array}$} \\
\hline & $\begin{array}{l}\text { Avg } \\
(n=3)\end{array}$ & Stdev & $\begin{array}{l}\text { Avg } \\
(n=3)\end{array}$ & Stdev & \\
\hline Unamended Sand & 0.76 & 0.04 & 0.64 & 0.05 & 9.12 \\
\hline 5\% Baked Apatite II & 0.31 & 0.03 & 0.33 & 0.23 & {$[6.06]$} \\
\hline 5\% Enzymatic Apatite II & 0.40 & 0.30 & 1.10 & 0.48 & {$[63.64]$} \\
\hline 5\% Mechanical Apatite II & 0.26 & 0.13 & 2.48 & 1.87 & [89.52] \\
\hline $5 \%$ SulfiTech & 0.70 & 0.06 & 0.70 & 0.16 & n.a. ${ }^{1}$ \\
\hline 1\% Buffer Block \#5 & 0.94 & 0.25 & 0.57 & 0.15 & 39.36 \\
\hline 3\% Buffer Block \#5 & 0.52 & 0.01 & 0.40 & 0.01 & 22.22 \\
\hline \multirow[t]{3}{*}{ 5\% Buffer Block \#5 } & 0.67 & 0.10 & 0.40 & 0.04 & 40.30 \\
\hline & \multicolumn{2}{|c|}{$\begin{array}{c}\text { Pre-DDI S\&S Copper } \\
\mathrm{mg} / \mathrm{L}\end{array}$} & \multicolumn{2}{|c|}{$\begin{array}{c}\text { Post-DDI S\&S Copper } \\
\text { mg/L }\end{array}$} & \multirow[b]{2}{*}{$\begin{array}{l}\text { \% Reduction } \\
\text { [Increase] }\end{array}$} \\
\hline & $\begin{array}{l}\text { Avg } \\
(n=3)\end{array}$ & Stdev & $\begin{array}{l}\text { Avg } \\
(n=3)\end{array}$ & Stdev & \\
\hline Unamended Sand & $<0.01^{2}$ & 0.00 & $<0.02$ & 0.01 & {$[50.00]$} \\
\hline 5\% Baked Apatite II & $<0.01$ & 0.00 & $<0.01$ & 0.00 & n.a. \\
\hline 5\% Enzymatic Apatite II & 0.02 & 0.00 & 0.12 & 0.00 & [83.33] \\
\hline 5\% Mechanical Apatite II & 0.03 & 0.01 & 0.07 & 0.01 & {$[57.14]$} \\
\hline $5 \%$ SulfiTech & $<0.01$ & 0.00 & $<0.01$ & 0.00 & n.a. \\
\hline 1\% Buffer Block \#5 & $<0.01$ & 0.00 & $<0.01$ & 0.00 & n.a. \\
\hline 3\% Buffer Block \#5 & $<0.01$ & 0.00 & $<0.01$ & 0.00 & n.a. \\
\hline 5\% Buffer Block \#5 & $<0.01$ & 0.01 & $<0.01$ & 0.00 & n.a. \\
\hline
\end{tabular}

The average lead, copper, and DOC leachate concentrations leaving the Mechanical and Enzymatic Apatite II amended berm sand exceeded the Barksdale permit limits (Table 17). The leachate concentrations for the SulfiTech and Buffer Block \# 5 amended berm sand performed better than the control (with no amendments), when examination of the average leachate DOC is taken into account. Essentially, the SulfiTech and Buffer Block \#5 amendments created a biologically inert matrix within the lysimeter cells, which prevented significant DOC generation, while maintaining acceptable $\mathrm{pH}$ and leachate metals concentrations. 
Table 17. Lysimeter cell leachate values for lead, copper, DOC, and pH (16-week average). Shading indicates values that meet selection criteria outlined in the objectives.

\begin{tabular}{|c|c|c|c|c|c|c|}
\hline \multirow[b]{3}{*}{ Amendment } & \multicolumn{6}{|c|}{ Average Value $(n=16)$} \\
\hline & \multicolumn{2}{|c|}{ Lead, $\mathrm{mg} / \mathrm{L}$} & \multicolumn{2}{|c|}{ Copper, mg/L } & \multirow{2}{*}{$\begin{array}{l}\mathrm{DOC} \\
\mathrm{mg} / \mathrm{L}\end{array}$} & \multirow[b]{2}{*}{$\mathrm{pH}$} \\
\hline & Filtered & Total & Filtered & Total & & \\
\hline Barksdale AFB Permit Limit & \multicolumn{2}{|l|}{0.150} & \multicolumn{2}{|l|}{0.500} & 50 & 6 to 9 \\
\hline Control - No amendment & $<0.026^{1}$ & $<0.022$ & $<0.011$ & $<0.011$ & 74.3 & 7.46 \\
\hline 5\% Baked Apatite II & $<0.077$ & 0.734 & $<0.021$ & $<0.052$ & 3.4 & 7.97 \\
\hline 5\% Enzymatic Apatite II & 0.620 & 1.833 & 14.772 & 14.694 & 273.5 & 8.78 \\
\hline 5\% Mechanical Apatite II & 0.632 & 2.267 & 21.478 & 21.560 & 357.0 & 8.71 \\
\hline $5 \%$ SulfiTech & $<0.018$ & $<0.028$ & $<0.093$ & $<0.036$ & 3.0 & 7.28 \\
\hline 1\% Buffer Block \#5 & $<0.018$ & 0.137 & $<0.034$ & $<0.013$ & 2.1 & 7.85 \\
\hline 3\% Buffer Block \#5 & $<0.016$ & $<0.016$ & $<0.026$ & $<0.010$ & 2.5 & 7.75 \\
\hline 5\% Buffer Block \#5 & $<0.013$ & $<0.021$ & $<0.020$ & $<0.013$ & 2.3 & 7.88 \\
\hline
\end{tabular}

Tables 18 and 19 summarize the average metals concentrations leaving the lysimeter cell as soluble and total digested leachate; runoff values are located in Appendix A. As the amount of Buffer Block \#5 amendment was increased, there was a noticeable increase in chromium leaving the cell. By the tenth rain event, chromium was effectively flushed from the cells. The increase in chromium is associated with the buffer blocks because of the Portland cement used in their production. The average concentration of chromium in Buffer Block \# 5 was $13.87 \mathrm{mg} / \mathrm{kg}$. Sources of Portland cement that have low concentrations of chromium are commercially available for use in buffer block formulations to reduce the release of chromium.

The Apatite II amended cells had higher concentrations of iron, manganese, vanadium, and antimony (Tables 18 and 19); these elevated concentrations are potentially metal ligands/colloids caused by the biological activity associated with the mechanically and enzymatically produced Apatite II. In addition, the SulfiTech-amended berm sand released less antimony than all of the other amendments including the control cell. 
Table 18. Soluble leachate metals from lysimeter cell (16-week average).

\begin{tabular}{|c|c|c|c|c|c|c|c|c|}
\hline \multirow[b]{2}{*}{ Amendment } & \multicolumn{8}{|c|}{ Average Soluble Concentration, $\mathrm{mg} / \mathrm{L}$} \\
\hline & $\mathrm{Cr}$ & $\mathrm{Ni}$ & $\mathrm{Zn}$ & $\mathrm{Fe}$ & $\mathrm{Mn}$ & Mo & $\mathrm{V}$ & $\mathrm{Sb}$ \\
\hline $\begin{array}{l}\text { Control - No } \\
\text { Amendment }\end{array}$ & $<0.010^{1}$ & $<0.010$ & $<0.010$ & $<0.010$ & $<0.616$ & $<0.010$ & $<0.011$ & 0.534 \\
\hline $\begin{array}{l}\text { 5\% Baked } \\
\text { Apatite II }\end{array}$ & $<0.010$ & $<0.010$ & $<0.010$ & 0.756 & $<0.026$ & $<0.010$ & $<0.017$ & 4.602 \\
\hline $\begin{array}{l}\text { 5\% Enzymatic } \\
\text { Apatite II }\end{array}$ & $<0.010$ & $<0.025$ & $<0.017$ & 0.374 & 0.429 & $<0.015$ & $<0.041$ & 5.439 \\
\hline $\begin{array}{l}\text { 5\% Mechanical } \\
\text { Apatite II }\end{array}$ & $<0.010$ & $<0.013$ & $<0.025$ & 0.266 & 0.229 & $<0.014$ & $<0.035$ & 7.206 \\
\hline $5 \%$ SulfiTech & $<0.010$ & $<0.010$ & $<0.013$ & $<0.010$ & $<0.013$ & $<0.010$ & $<0.012$ & 0.116 \\
\hline $\begin{array}{l}\text { 1\% Buffer } \\
\text { Block \#5 }\end{array}$ & $<0.011$ & $<0.010$ & $<0.010$ & $<0.012$ & $<0.010$ & $<0.010$ & $<0.011$ & 0.924 \\
\hline $\begin{array}{l}\text { 3\% Buffer } \\
\text { Block \#5 }\end{array}$ & $<0.017$ & $<0.010$ & $<0.010$ & $<0.010$ & $<0.010$ & $<0.011$ & $<0.012$ & 0.897 \\
\hline $\begin{array}{l}5 \% \text { Buffer } \\
\text { Block \#5 }\end{array}$ & $<0.051$ & $<0.010$ & $<0.010$ & $<0.010$ & $<0.010$ & $<0.017$ & $<0.011$ & 0.584 \\
\hline
\end{tabular}

Table 19. Total leachate metals from lysimeter cell (16-week average).

\begin{tabular}{|c|c|c|c|c|c|c|c|c|}
\hline \multirow[b]{2}{*}{ Amendment } & \multicolumn{8}{|c|}{ Average Digested Concentration, $\mathrm{mg} / \mathrm{L}$} \\
\hline & $\mathrm{Cr}$ & $\mathrm{Ni}$ & $\mathrm{Zn}$ & $\mathrm{Fe}$ & $\mathrm{Mn}$ & Mo & $\mathrm{V}$ & $\mathrm{Sb}$ \\
\hline $\begin{array}{l}\text { Control - No } \\
\text { amendment }\end{array}$ & $<0.010^{1}$ & $<0.010$ & $<0.017$ & 0.043 & $<0.527$ & $<0.010$ & $<0.012$ & 0.438 \\
\hline $\begin{array}{l}\text { 5\% Baked } \\
\text { Apatite II }\end{array}$ & $<0.010$ & $<0.009$ & $<0.025$ & 1.309 & 0.208 & $<0.010$ & $<0.020$ & 3.765 \\
\hline $\begin{array}{l}\text { 5\% Enzymatic } \\
\text { Apatite II }\end{array}$ & $<0.010$ & $<0.025$ & $<0.039$ & 0.294 & 0.687 & $<0.012$ & 0.044 & 4.732 \\
\hline $\begin{array}{l}\text { 5\% Mechanical } \\
\text { Apatite II }\end{array}$ & $<0.010$ & $<0.016$ & $<0.036$ & 0.248 & 0.379 & $<0.011$ & 0.039 & 6.179 \\
\hline $5 \%$ SulfiTech & $<0.010$ & $<0.009$ & $<0.018$ & 0.034 & $<0.012$ & $<0.011$ & $<0.013$ & 0.090 \\
\hline $\begin{array}{l}\text { 1\% Buffer Block } \\
\# 5\end{array}$ & $<0.011$ & $<0.010$ & $<0.013$ & 0.077 & $<0.011$ & $<0.010$ & $<0.012$ & 0.774 \\
\hline $\begin{array}{l}\text { 3\% Buffer Block } \\
\# 5\end{array}$ & $<0.017$ & $<0.010$ & $<0.014$ & 0.042 & $<0.010$ & $<0.010$ & $<0.013$ & 0.768 \\
\hline $\begin{array}{l}\text { 5\% Buffer Block } \\
\# 5\end{array}$ & $<0.045$ & $<0.010$ & $<0.016$ & 0.060 & $<0.010$ & $<0.013$ & $<0.012$ & 0.494 \\
\hline
\end{tabular}


The lysimeter study is designed to provide a large volume of water in a short period of time. Under these rainfall conditions, while the ability to collect equal volumes of runoff and leachate exists, the slow rainfall events are not simulated that allow for the rainwater to percolate into the sand. These observations may help to explain why not all of the cells achieved the permit limit for total runoff lead concentrations (Table 20).

Table 20. Lysimeter cell runoff water (16-week average). Shading indicates values that meet selection criteria outlined in the objectives.

\begin{tabular}{|c|c|c|c|c|c|c|}
\hline \multirow[b]{3}{*}{ Amendment } & \multicolumn{6}{|c|}{ Parameter, average } \\
\hline & \multicolumn{2}{|c|}{ Lead, $\mathrm{mg} / \mathrm{L}$} & \multicolumn{2}{|c|}{ Copper, mg/L } & \multirow[b]{2}{*}{$\mathrm{DOC}, \mathrm{mg} / \mathrm{L}$} & \multirow[b]{2}{*}{$\mathrm{pH}$} \\
\hline & Filtered & Total & Filtered & Total & & \\
\hline Barksdale AFB Permit Limit & \multicolumn{2}{|l|}{0.150} & \multicolumn{2}{|l|}{0.500} & 50 & 6 to 9 \\
\hline Control - No amendment & $<0.026^{1}$ & 1.522 & $<0.010$ & $<0.031$ & 19.8 & 7.00 \\
\hline 5\% Baked Apatite II & $<0.023$ & 0.305 & $<0.016$ & $<0.013$ & 2.2 & 6.89 \\
\hline 5\% Enzymatic Apatite II & $<0.057$ & 2.512 & $<0.054$ & 0.115 & 1.8 & 6.88 \\
\hline 5\% Mechanical Apatite II & $<0.106$ & 1.706 & $<0.049$ & $<0.067$ & 2.2 & 6.35 \\
\hline $5 \%$ SulfiTech & $<0.081$ & 1.309 & $<0.038$ & $<0.026$ & 1.4 & 7.64 \\
\hline 1\% Buffer Block \#5 & $<0.020$ & 0.462 & $<0.009$ & $<0.015$ & 1.2 & 7.08 \\
\hline 3\% Buffer Block \#5 & $<0.043$ & 2.537 & $<0.013$ & $<0.053$ & 0.9 & 9.33 \\
\hline $5 \%$ Buffer Block \#5 & $<0.030$ & 0.739 & $<0.010$ & $<0.018$ & 1.0 & 8.07 \\
\hline
\end{tabular}

A direct correlation exists between the amount of TSS leaving the lysimeter as runoff and leachate and the total lead leaving the lysimeter as runoff and leachate (Figure 16). In general, as more solids left the lysimeter, the lead associated with the solids also left the lysimeter. The correlation coefficient for the lead associated with the TSS in the runoff is o.6976; in the leachate, 0.9484 . 


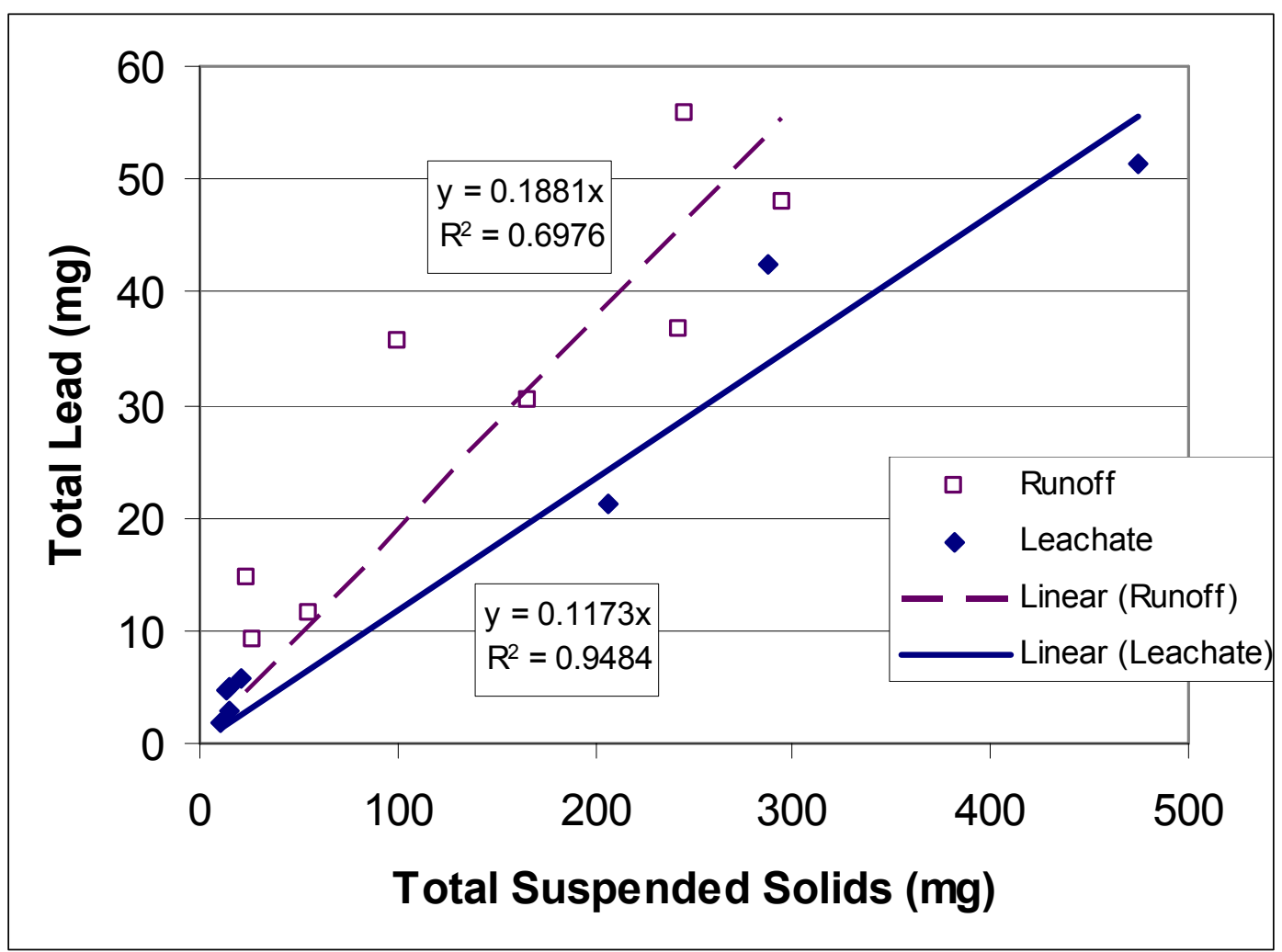

Figure 16. TSS and total lead from the 16 rain events for each amended soil and the correlation between TSS and amount of lead leaving the system as runoff and leachate.

The column study was a relatively simple experiment used for evaluating the effectiveness of the amendments on containing metals within the PRBerm material, but it provided only general results and trends. Due to the small volume of material and amendments used in typical column studies, the results may potentially be dominated by a subsample placed in the column that is not representative of the bulk material. The lysimeters use a larger volume of material and thus reduce the potential of using a subsample that is not representative of the bulk material. The subsamples used in the column studies and the second lysimeter study are from the same bulk berm material. The amount of total lead leaving as leachate for columns and lysimeters, summed up over the 16 rain events, and normalized by the mass of lead in each column or lysimeter cell is substantially different for the Apatite II and Buffer Block-amended columns versus the lysimeters (Figure 17). Additional results for soluble lead and copper in the leachate are in Appendix A. Substantially more copper was leaving the mechanically and enzymatically produced Apatite II-amended lysimeter cells than the other amended cells. As discussed earlier, this is probably due to the biological activity and associated metal ligand/colloids produced in those lysimeter cells. 


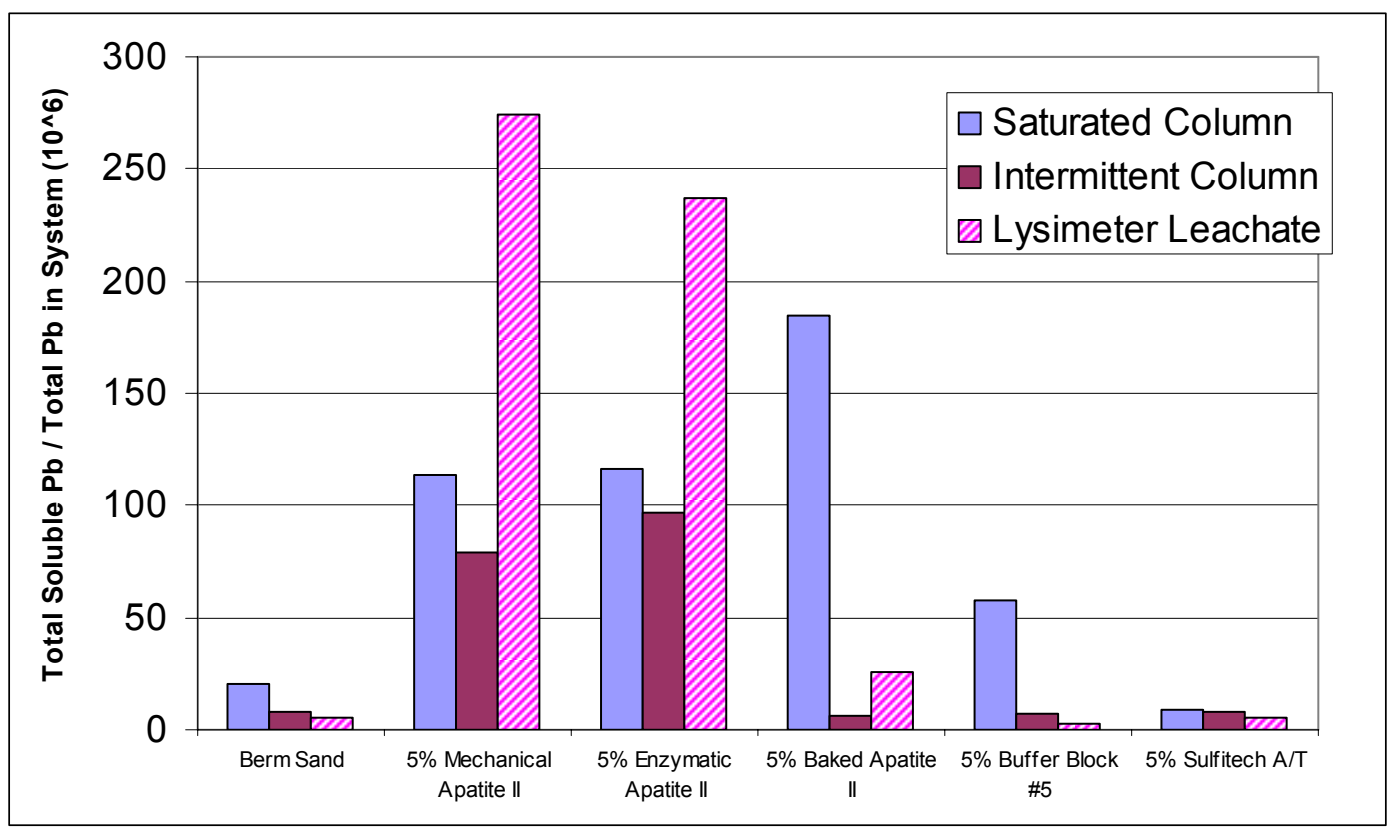

Figure 17. Sum of soluble lead leaving the columns and lysimeters.

When comparing the total lead lost in the soluble and total digest forms as leachate from the lysimeter cells, the Buffer Block \#5 and SulfiTech amendments greatly reduced the total amount of all metals leaching from the lysimeter cells (Tables 21 and 22). When you normalize the total lead lost by the amount of lead in the cell, the 3 and 5 percent Buffer Block \# 5 still decreased the amount of lead leaving the cell as leachate (based on the control cell) compared to the other amendments.

Table 21. Total soluble lead in leachate normalized based on total lead in cell.

\begin{tabular}{|c|c|c|c|c|c|}
\hline Amendment & $\begin{array}{l}\text { Soluble } \\
\text { Lead Lost } \\
\text { mg }\end{array}$ & \begin{tabular}{|l}
$\%$ \\
Reduction \\
[Increase]
\end{tabular} & $\begin{array}{l}\text { Initial Lead } \\
\text { in Cell } \\
\mathrm{g}^{1}\end{array}$ & $\begin{array}{l}\text { Soluble } \\
\text { Lead/Initial } \\
\text { Lead }\end{array}$ & \begin{tabular}{|l}
$\%$ \\
Reduction \\
[Increase]
\end{tabular} \\
\hline Control - no amendment & $<0.493^{2}$ & n.a. ${ }^{3}$ & 90.177 & 0.0055 & n.a. \\
\hline 5\% Baked Apatite II & $<1.828$ & [73.03] & 70.844 & 0.0258 & [78.68] \\
\hline 5\% Enzymatic Apatite II & 15.067 & [96.73] & 63.565 & 0.2370 & [97.68] \\
\hline 5\% Mechanical Apatite II & 17.298 & [97.15] & 63.11 & 0.2741 & [97.99] \\
\hline $5 \%$ SulfiTech & $<0.327$ & 33.67 & 66.294 & 0.0049 & 10.91 \\
\hline 1\% Buffer Block \#5 & $<0.402$ & 18.46 & 67.432 & 0.0060 & {$[8.33]$} \\
\hline 3\% Buffer Block \#5 & $<0.297$ & 39.76 & 74.255 & 0.0040 & 27.27 \\
\hline 5\% Buffer Block \#5 & $<0.210$ & 57.40 & 73.346 & 0.0029 & 47.27 \\
\hline \multicolumn{6}{|c|}{$\begin{array}{l}1 \text { Based on soil digests and mass soil used in cell. } \\
2 \text { IDL used in calculations. } \\
3 \text { n.a. = not applicable. }\end{array}$} \\
\hline
\end{tabular}


Table 22. Total digested lead in leachate normalized based on total lead in cell.

\begin{tabular}{|c|c|c|c|c|c|}
\hline Amendment & $\begin{array}{l}\text { Total Lead } \\
\text { Lost, mg }\end{array}$ & $\begin{array}{l}\text { \% Reduction } \\
\text { [Increase] }\end{array}$ & $\begin{array}{l}\text { Initial Lead } \\
\text { g1 }^{1}\end{array}$ & $\begin{array}{l}\text { Total } \\
\text { Lead/Initial } \\
\text { Lead }\end{array}$ & $\begin{array}{l}\text { \% Reduction } \\
\text { [Increase] }\end{array}$ \\
\hline Control - no amendment & 5.789 & n.a. ${ }^{3}$ & 90.177 & 0.0642 & n.a. \\
\hline 5\% Baked Apatite II & 21.116 & {$[72.58]$} & 70.844 & 0.2981 & {$[78.46]$} \\
\hline 5\% Enzymatic Apatite II & 42.487 & {$[86.37]$} & 63.565 & 0.6684 & [90.40] \\
\hline 5\% Mechanical Apatite II & 51.272 & {$[88.71]$} & 63.11 & 0.8124 & [92.10] \\
\hline $5 \%$ SulfiTech & 4.669 & 19.35 & 66.294 & 0.0704 & {$[8.81]$} \\
\hline 1\% Buffer Block \#5 & 4.939 & 14.68 & 67.432 & 0.0732 & {$[12.30]$} \\
\hline 3\% Buffer Block \#5 & 1.799 & 68.92 & 74.255 & 0.0242 & 62.31 \\
\hline 5\% Buffer Block \#5 & 2.897 & 49.96 & 73.346 & 0.0395 & 38.47 \\
\hline \multicolumn{6}{|c|}{$\begin{array}{l}1 \text { Based on soil digests and mass soil used in cell. } \\
2 \text { IDL used in calculations. } \\
{ }^{3} \text { n.a. = not applicable. }\end{array}$} \\
\hline
\end{tabular}




\section{Conclusions and Recommendations}

\section{Conclusions}

The results from this study will be used to develop and improve SAFR berm technology through the incorporation of nonreactive ballistic sand with an amendment(s) that will contain metals within the PRBerm. Four regulatory drivers were used as criteria to qualify an amendment(s) for use during the field demonstration. Compared to the other amendments, Buffer Block \# 5 performed best under the column and lysimeter treatability study conditions. The treatability study results will be evaluated against the field demonstration results to determine the BMPs for the PRBerm application.

The specific objectives of this treatability study have been met. These are:

- Appropriate well-graded ballistic sand for use in the PRBerm field demonstration, using Barksdale AFB as a local reference, was determined to be the Red River sand.

- Treatability studies determined the appropriate sand-to-amendment ratio of 5 percent (w/w). This was sufficient to contain metals within the berm material. A field demonstration at an active SAFR will confirm if the 5 percent amendment ratio is sufficient under natural conditions.

- Buffer Block \#5 and SulfiTech A/T appear to be suitable amendments for use in the field demonstration. In the treatability study they:

- Maintained leachate lead and copper concentrations below the permit limit of $0.150 \mathrm{mg} / \mathrm{L}$ and $0.500 \mathrm{mg} / \mathrm{L}$, respectively,

- Maintained a pH between 6 and 9 in the leachate and runoff waters, and

- Maintained a DOC at less than $50 \mathrm{mg} / \mathrm{L}$ for the leachate and runoff waters.

\section{Recommendations}

The PRBerm is not suitable for all range backstops. Range operations and range soil conditions dictate what type of application, if any, is needed in order to reduce metals migration off the SAFRs. An alternative to the PRBerm is a fully contained bullet trap system. Although the bullet trap 
will reduce the potential metals migration into the environment, significant cost and loss to training value is associated with such a system.

Our investigation determined that some amendments will potentially sequester metals within the PRBerm matrix. Of the amendments that we investigated, the Buffer Block \# 5 and the SulfiTech A/T performed the best under laboratory conditions at decreasing metals migration when used in a lysimeter. Not all of the potential amendments that could work in the PRBerm were investigated in this study due to the experimental parameters, such as time and necessary resources, which limited the scope of the treatability study. The results and general observations indicate that, for the best results within the PRBerm matrix, the sand and amendment need to be weather tolerant and somewhat inert.

Although Apatite II performed best under pre- and post-TCLP conditions, the Apatite II was unsuitable as an amendment source under the PRBerm conditions. Initially, the Apatite II amendments did not perform as expected, but over time the reduction of lead leaving the lysimeter cells did decrease with the use of Apatite II as an amendment source. The organic matter may be a contributing factor associated with the lapse in increased lead and copper reduction associated with the Apatite II.

Buffer Block \#5 and SulfiTech A/T amendments will potentially be field demonstrated under ESTCP project ER-0406 as they have proven successful in the treatability studies to date. Many factors are not addressed in the treatability study and could not be accounted for under laboratory procedures, which shall be addressed during the field demonstration. These include:

- The effects of bullet loading on the amendment operation and regeneration during full-scale operation of the PRBerm at an active SAFR,

- Amendment replacement rate and necessity,

- Specific berm design factors,

- Additional environmental impacts that may contribute to the operation of the PRBerm, and

- Cost analysis of operating and maintaining a PRBerm on an active SAFR. 


\section{References}

American Public Health Association. 1998. Standard methods for the examination of water and wastewater. Method 3010. Andrew D. Eaton, Lenore S. Clesceri, Arnold E. Greenberg, Mary Ann H. Franson, ed., 20th ed., prepared and published jointly by American Public Health Association, American Water Works Association, Water Environment Federation, Washington, DC.

American Society for Testing and Materials. 2001. ASTM D422, D854, and D2487. West Conshohocken, PA.

American Society for Testing and Materials. 2001. Standard test method for leaching solid material in column apparatus. ASTM D4874-95. West Conshohocken, PA.

Berti, W. R., and S. D. Cunningham. 1997. In-place inactivation of Pb in Pb-contaminated soils. Environmental Science and Technology 31, 1359-1364.

Cao, X., L. O. Ma, M. Chen, D. W. Hardison, Jr., and W. G. Harris. 2003. Weathering of lead bullets and their environmental effects at outdoor shooting ranges. J. of Environmental Quality 32, 526-534.

Conca, J. L., N. Lu, G. Parker, B. Moore, A. Adams, J. Wright, and P. Heller. 200o. PIMSremediation of metal contaminated waters and soils. Remediation of Chlorinated Recalcitrant Compounds 7, 319-326.

Chemical Rubber Company (CRC). 2004. Handbook of Chemistry and Physics, 84th Edition.

Engineering Technical Letter (ETL) 02-11: Small Arms Range Design and Construction (2002). Department of the Air Force, Tyndall AFB, FL.

Fabian, G. L. 2005. Army small arms training range environmental best management practices (BMP) manual. U.S. Army Environmental Center.

Headquarters, Department of the Army (HQDA). 1996. Army ammunition data sheets small caliber ammunition FSC 1305. Technical Manual (TM) 43-0001-27. Washington, DC.

Holmgren, G. G., M. W. Meyer, R. L. Chaney, and R. B. Daniels. 1993. Cadmium, lead, copper, and nickel in agricultural soils of the United States of America. J. of Environmental Quality 22:335-348.

Houlihan, J., and R. Wiles. 2002. Lead pollution at outdoor firing ranges. Washington, DC: Environmental Working Group. Available at: www.ewg.org/reports/ poisonouspastime/leadpoll.pdf

Interstate Technology and Regulatory Council (ITRC). 2003. Characterization and remediation of soils at closed small arms firing ranges. . 2005. Environmental management at operating outdoor small arms firing ranges. 
Lambert, M., G. Pierzynski, L. Erickson, and J. Schnoor. 1997. Remediation of lead-, zincand cadmium-contaminated soils. Issues in environmental science and technology; No. 7, Contaminated land and its reclamation, R. E. Hester and R. M. Harrison, ed., 91-102. Herts, United Kingdom: The Royal Society of Chemistry.

Larson, S. L, V. F. Medina, C. Teeter, and W. A. Martin. In press, 2007. Treatment and management of closed or inactive small arms firing ranges. ERDC/EL TR-07-6. Vicksburg, MS: U.S. Army Engineer Research and Development Center.

Lin, Z., B. Comet, U. Ovarfort, and R. Herbert. 1995. The chemical and mineralogical behavior of $\mathrm{Pb}$ in shooting range soils from central Sweden. Environmental Pollution 89, 303-309.

Lower, S. K., P. A. Maurice, and S. J. Traina. 1998. Simultaneous dissolution of hydroxylapatite and precipitation of hydroxypyromorphite: Direct evidence of homogeneous nucleation. Geoch. Cosmoch. Acta 62, 1773-1780.

Lu, N., J. Xu, J. Wright, and J. L. Conca. 2001. PIMS-remediation of metal-contaminated groundwater and soil using a special reactive form of the mineral apatite. Appl. Miner. Res. Econ. Technol., Ecol. Culture 2, 603-606.

Ma, Q. Y., and G. N. Rao. 1997. Effects of phosphate rock on sequential chemical extraction of lead in contaminated soils. J. of Environmental Quality 26:788-794.

Ma, Q. Y., S. J. Traina, T. J. Logan, and J. A. Ryan. 1994. Effects of aqueous Al, Cd, Cu, $\mathrm{Fe}(\mathrm{II}), \mathrm{Ni}$, and $\mathrm{Zn}$ on $\mathrm{Pb}$ immobilization by hydroxyapatite. Environmental Science and Technology 28, 1219-1228.

Manninen, S., and N. Tanskanen. 1993. Transfer of lead from shotgun pellets to humus and three plant species in a Finnish shooting range. Archives of Environmental Contamination and Toxicology 24:410-414.

Martinez, C. E., A. R. Jacobson, and M. B. McBride. 2004. Lead phosphate minerals: Solubility and dissolution by models and natural ligands. Environmental Science and Technology 38, 5584-5590.

Murray, K., A. Babzzi, C. Carter, A. Ehlert, and M. Kopec. 1997. Distribution and mobility of lead in soils at an outdoor shooting range. Journal of Soil Contaminations 6, 79-63.

Pearson, M. S., K. Maenpaa, and G. M. Pierzynski. 2000. Effects of soil amendments on the bioavailability of lead, zinc and cadmium to earthworms. Journal of Environmental Quality 29, 1611-17.

Shinomiya, T., K. Shinomiya, C. Orimoto, T. Minami, Y. Tohno, and M. Yamada. 1998. In- and out-flows of elements in bones embedded in reference soils. Forensic Sci. Int. 98, 109-118.

Stack, A. G., R. Erni, N. D. Browning, and W. H. Casey. 2004. Pyromorphite growth on lead-sulfide surfaces. Environ. Sci. Technol. 38, 5529-5534.

Tardy, B. A., R. M. Bricka, and S. L. Larson. 2003. Chemical stabilization of lead in small arms firing range soils. ERDC/EL TR-03-20. Vicksburg, MS: U.S. Army Engineer Research and Development Center. 
Traina, S. J., and V. Laperche. 1999. Contaminant bioavailability in soils, sediments, and aquatic environments. Proc. Natl. Acad. Sci. USA 96, 3365-3371.

U.S. Environmental Protection Agency (USEPA). 1999. Test methods for evaluating solid waste, physical/chemical methods. SW-846. Washington, DC.

. 2001a. Indoor Environment Division: Lead fact sheet. Office of Emergency and Remedial Response. www.epa.gov/iaq/lead.html

.2001b. Best management practices for lead at outdoor shooting ranges.

EPA/902-B-01-001. New York: RCRA Compliance Branch.

. 2001c. Providing solutions for a better tomorrow: Reducing the risks associated with lead in soil. EPA/600-F-01/014. Washington, DC: Office of Research and Development.

2002. Lead in drinking water regulation: Public education guidance. EPA 816-R-02-010. Washington, DC. Available on line at: http://www.epa.gov/safewater/ Icrmr/implement.html

.2003. America's children and the environment: Measures of contaminants, body burdens, and illnesses (2nd ed.). EPA/240-R-03001. Washington, DC: Office of Children's Health Protection.

United States Patent and Trademark Office (USPTO). 2001. Low-lead leaching foamed concrete bullet barrier. U.S. Patent No. 6,264,735, Washington, DC.

. 2002. Sulfite treatment of spent industrial wastes. U.S. Patent No. 6,476,287. Washington, DC.

. 2003. Material, and method of producing it, for immobilizing heavy metals later entrained therein. U.S. Patent No. 6,620,236. Washington, DC.

. 2004. Sulfite treatment of spent industrial wastes. U.S. Patent No. 6,680,039. Washington, DC.

. 2005. Self-dispensing bullet trap buffer block. U.S. Patent Application No. 20050006849. Washington, DC.

Vaccari, D. A. 1992. Computation of aqueous metal solubilities using spreadsheet programs. Hoboken, NJ: Stevens Institute of Tech. Available at: http://www.attila.stevens-tech.edu

Weiss, C. A., P. G. Malone, J.R. Tom, E. J. Fransen, and J. Peiten. 2005. Modeling physical and chemical changes during bullet trapping and recovery. 6th Annual Environmental Technology Symposium and Workshop, Portland, OR.

Wright, J., K. R. Rice, B. Murphy, and J. L. Conca. 2004. Pims using Apatite II: Remediation of $\mathrm{Pb}$-contaminated range soil at Camp Stanley storage activity, TX. Proceedings of the Conference on Sustainable Range Management. New Orleans, $L A$. 


\section{Appendix A}

\section{Preliminary sand evaluation data}

Table A-1. Background metals concentrations in digested sands.

\begin{tabular}{|c|c|c|c|c|c|c|c|c|c|c|}
\hline \multirow[b]{2}{*}{ Sand } & \multicolumn{10}{|c|}{ Average Concentration $(\mathrm{n}=3), \mathrm{mg} / \mathrm{kg}$} \\
\hline & $\mathrm{Pb}$ & $\mathrm{Cr}$ & $\mathrm{Cu}$ & $\mathrm{Ni}$ & $\mathrm{Zn}$ & $\mathrm{Fe}$ & $\mathrm{Mn}$ & Mo & V & $\mathrm{Sb}$ \\
\hline Red River & 9.96 & 5.01 & 1.80 & 2.18 & 4.97 & $3,335.00$ & 77.77 & 0.37 & 6.91 & 1.04 \\
\hline Tri-State Concrete & 6.39 & 5.02 & 1.81 & 1.57 & 2.75 & $1,720.67$ & 12.14 & 0.15 & 5.28 & 0.26 \\
\hline Tri-State Mason & 7.35 & 2.48 & 2.14 & 1.11 & 2.91 & 960.77 & 7.86 & 0.14 & 3.10 & 0.40 \\
\hline Madden Screenings & 15.80 & 19.47 & 15.08 & 12.91 & 45.07 & $12,940.00$ & 327.40 & 2.18 & 42.64 & $<0.05$ \\
\hline Play Sand & n.d. ${ }^{1}$ & n.d. & n.d. & n.d. & n.d. & n.d. & n.d. & n.d. & n.d. & n.d. \\
\hline
\end{tabular}

\section{Amendment selection (TCLP, DDI S\&S, 3-day leaching)}

Table A-2. Comparison of TLCP leaching from SAFR berm soil ${ }^{1}$ by amendment.

\begin{tabular}{|c|c|c|c|c|c|c|c|c|c|c|}
\hline \multirow[b]{2}{*}{ Amendment } & \multicolumn{10}{|c|}{ Average Concentration $(\mathrm{n}=3), \mathrm{mg} / \mathrm{L}$} \\
\hline & $\mathrm{Pb}$ & $\mathrm{Cr}$ & $\mathrm{Cu}$ & $\mathrm{Ni}$ & $\mathrm{Zn}$ & $\mathrm{Fe}$ & $\mathrm{Mn}$ & Mo & V & $\mathrm{Sb}$ \\
\hline Control - no amendment & 8.29 & $<0.05^{2}$ & 0.18 & $<0.05$ & $<0.05$ & 0.05 & $<0.05$ & $<0.05$ & $<0.05$ & 0.16 \\
\hline 1\% Crushed Bone Apatite II & 2.23 & $<0.05$ & 0.12 & $<0.05$ & $<0.05$ & 0.28 & $<0.05$ & $<0.05$ & $<0.05$ & 0.12 \\
\hline 3\% Crushed Bone Apatite II & 0.34 & $<0.05$ & 0.06 & $<0.05$ & $<0.05$ & 0.12 & $<0.05$ & $<0.05$ & $<0.05$ & 0.1 \\
\hline 5\% Crushed Bone Apatite II & 0.28 & $<0.05$ & 0.09 & $<0.05$ & $<0.05$ & $<0.08$ & $<0.05$ & $<0.05$ & $<0.05$ & 0.09 \\
\hline $\begin{array}{l}\text { 10\% Crushed Bone } \\
\text { Apatite II }\end{array}$ & 0.06 & $<0.05$ & $<0.05$ & $<0.05$ & $<0.05$ & $<0.05$ & $<0.05$ & $<0.05$ & $<0.05$ & 0.12 \\
\hline 5\% Buffer Block \#1 & 4.52 & 0.07 & $<0.09$ & $<0.05$ & 0.050 & $<0.05$ & $<0.05$ & $<0.05$ & $<0.05$ & $<0.05$ \\
\hline 5\% Buffer Block \#2 & 2.58 & $<0.05$ & $<0.06$ & $<0.05$ & $<0.05$ & $<0.05$ & $<0.05$ & $<0.05$ & $<0.05$ & $<0.05$ \\
\hline 5\% Buffer Block \#3 & 1.07 & 0.07 & $<0.05$ & $<0.06$ & $<0.05$ & $<0.05$ & $<0.06$ & $<0.05$ & $<0.05$ & $<0.05$ \\
\hline 5\% Buffer Block \#4 & 0.7 & 0.11 & $<0.05$ & $<0.05$ & $<0.05$ & $<0.05$ & $<0.05$ & $<0.05$ & $<0.05$ & $<0.05$ \\
\hline $\begin{array}{l}\text { 2.5\% Crushed Bone } \\
\text { Apatite II and 2.5\% Buffer } \\
\text { Block \#4 }\end{array}$ & 0.2 & 0.08 & $<0.05$ & $<0.05$ & $<0.05$ & $<0.05$ & $<0.05$ & $<0.05$ & $<0.05$ & $<0.05$ \\
\hline
\end{tabular}


Table A-3. DDI S\&S leaching evaluation of SAFR berm soil ${ }^{1}$ by amendment.

\begin{tabular}{|c|c|c|c|c|c|c|c|c|c|c|}
\hline \multirow[b]{2}{*}{ Amendment } & \multicolumn{10}{|c|}{ Average Concentration $(n=3), \mathrm{mg} / \mathrm{L}$} \\
\hline & $\mathrm{Pb}$ & $\mathrm{Cr}$ & $\mathrm{Cu}$ & $\mathrm{Ni}$ & $\mathrm{Zn}$ & $\mathrm{Fe}$ & $\mathrm{Mn}$ & Mo & $\mathrm{V}$ & $\mathrm{Sb}$ \\
\hline $\begin{array}{l}\text { Control - } \\
\text { no amendment }\end{array}$ & 0.26 & $<0.05$ & $<0.05$ & $<0.05$ & $<0.05$ & 1.69 & $<0.05$ & $<0.05$ & $<0.05$ & $<0.05$ \\
\hline $\begin{array}{l}\text { 1\% Crushed Bone } \\
\text { Apatite II }\end{array}$ & 0.23 & $<0.05$ & $<0.05$ & $<0.05$ & $<0.05$ & 1.34 & $<0.05$ & $<0.05$ & $<0.05$ & $<0.05$ \\
\hline $\begin{array}{l}\text { 3\% Crushed Bone } \\
\text { Apatite II }\end{array}$ & 0.4 & $<0.05$ & $<0.05$ & $<0.05$ & $<0.05$ & 2.42 & $<0.05$ & $<0.05$ & $<0.05$ & \\
\hline $\begin{array}{l}\text { 5\% Crushed Bone } \\
\text { Apatite II }\end{array}$ & 0.09 & $<0.05$ & $<0.05$ & $<0.05$ & $<0.05$ & 0.5 & $<0.05$ & $<0.05$ & $<0.05$ & $<0.06$ \\
\hline $\begin{array}{l}\text { 10\% Crushed Bone } \\
\text { Apatite II }\end{array}$ & 0.1 & $<0.05$ & $<0.05$ & $<0.05$ & $<0.05$ & 0.35 & $<0.05$ & $<0.05$ & $<0.05$ & $<0.05$ \\
\hline 5\% Buffer Block \#1 & 0.17 & $<0.05$ & $<0.05$ & $<0.05$ & $<0.05$ & 0.09 & $<0.05$ & $<0.05$ & $<0.05$ & $<0.05$ \\
\hline 5\% Buffer Block \#2 & 0.2 & 0.07 & $<0.05$ & $<0.05$ & $<0.05$ & $<0.05$ & $<0.05$ & $<0.05$ & $<0.05$ & $<0.05$ \\
\hline 5\% Buffer Block \#3 & 0.06 & 0.09 & $<0.05$ & $<0.05$ & $<0.05$ & $<0.05$ & $<0.05$ & $<0.05$ & $<0.05$ & $<0.05$ \\
\hline 5\% Buffer Block \#4 & $<0.08^{2}$ & 0.11 & $<0.05$ & $<0.05$ & $<0.05$ & $<0.05$ & $<0.05$ & $<0.05$ & $<0.05$ & $<0.05$ \\
\hline $\begin{array}{l}\text { 2.5\% Crushed Bone } \\
\text { Apatite II and } \\
2.5 \% \text { Buffer } \\
\text { Block \#4 }\end{array}$ & $<0.05$ & 0.12 & $<0.05$ & $<0.05$ & $<0.05$ & $<0.05$ & $<0.05$ & $<0.05$ & $<0.05$ & $<0.05$ \\
\hline
\end{tabular}

Table A-4. Three-day leaching evaluation of SAFR berm soil ${ }^{1}$ by amendment.

\begin{tabular}{|c|c|c|c|c|c|c|c|c|c|c|}
\hline \multirow[b]{2}{*}{ Amendment } & \multicolumn{10}{|c|}{ Average Concentration $(n=3), \mathrm{mg} / \mathrm{L}$} \\
\hline & $\mathrm{Pb}$ & $\mathrm{Cr}$ & $\mathrm{Cu}$ & $\mathrm{Ni}$ & $\mathrm{Zn}$ & $\mathrm{Fe}$ & $\mathrm{Mn}$ & Mo & V & $\mathrm{Sb}$ \\
\hline $\begin{array}{l}\text { Control - no } \\
\text { amendment }\end{array}$ & 2.80 & $<0.05^{2}$ & 0.1 & $<0.05$ & $<0.05$ & 7.69 & 0.09 & $<0.05$ & $<0.05$ & 0.25 \\
\hline $\begin{array}{l}\text { 5\% Whole Bone } \\
\text { Apatite II }\end{array}$ & 1.82 & $<0.05$ & 0.09 & $<0.05$ & $<0.05$ & 4.06 & $<0.05$ & $<0.05$ & $<0.05$ & 0.37 \\
\hline $\begin{array}{l}5 \% \text { Crushed } \\
\text { Bone Apatite II }\end{array}$ & 0.53 & $<0.05$ & $<0.05$ & $<0.05$ & $<0.05$ & 1.38 & $<0.05$ & $<0.05$ & $<0.05$ & 0.19 \\
\hline $\begin{array}{l}5 \% \text { Buffer } \\
\text { Block \#4 }\end{array}$ & 0.38 & 0.29 & $<0.05$ & $<0.05$ & $<0.05$ & $<0.05$ & $<0.05$ & $<0.05$ & $<0.05$ & $<0.05$ \\
\hline
\end{tabular}




\section{Aged amendment data}

Table A-5. Effects of aged Baked Apatite II on removal of lead from solution.

\begin{tabular}{|c|c|c|c|c|c|c|}
\hline \multirow[b]{2}{*}{ Days Aged } & \multicolumn{2}{|c|}{ Mechanical Apatite II } & \multicolumn{2}{|c|}{ Baked Apatite II } & \multicolumn{2}{|c|}{$\begin{array}{c}\text { Original Solution } \\
50 \mathrm{mg} \mathrm{Pb/L}\end{array}$} \\
\hline & $\operatorname{Avg}(n=3)$ & Stdev & $\operatorname{Avg}(n=3)$ & Stdev & $\operatorname{Avg}(n=3)$ & Stdev \\
\hline $0^{1}$ & 7.12 & 0.02 & 9.47 & 0.09 & \multirow{5}{*}{4.98} & \multirow{5}{*}{0.05} \\
\hline 3 & 7.11 & 0.04 & 9.22 & 0.09 & & \\
\hline 6 & 6.74 & 0.09 & 9.19 & 0.17 & & \\
\hline 10 & 7.08 & 0.03 & 8.86 & 0.07 & & \\
\hline 17 & 6.70 & 0.06 & 8.00 & 0.08 & & \\
\hline
\end{tabular}

Table A-6. Comparison of Mechanical and aged Baked Apatite II on removal of lead from solution over time.

\begin{tabular}{|c|c|c|c|c|c|c|c|c|c|c|c|c|c|}
\hline \multirow[b]{3}{*}{ Sample } & \multirow{3}{*}{$\begin{array}{l}\text { Aging } \\
\text { Day }\end{array}$} & \multicolumn{12}{|c|}{ Soluble $\mathrm{Pb}$ Concentration $(\mathrm{n}=3), \mathrm{mg} / \mathrm{L}$} \\
\hline & & \multicolumn{2}{|c|}{ Initial } & \multicolumn{2}{|c|}{30 Seconds } & \multicolumn{2}{|c|}{2 Minutes } & \multicolumn{2}{|c|}{5 Minutes } & \multicolumn{2}{|c|}{15 Minutes } & \multicolumn{2}{|c|}{30 Minutes } \\
\hline & & Avg & Stdev & Avg & Stdev & Avg & Stdev & Avg & Stdev & Avg & Stdev & Avg & Stdev \\
\hline \multirow{5}{*}{$\begin{array}{l}\text { Mechanical } \\
\text { Apatite II }\end{array}$} & $0^{1}$ & 45.04 & 0.27 & 7.42 & 4.61 & $2.53^{2}$ & 0.822 & 7.74 & 1.42 & 13.27 & 3.49 & 12.03 & 3.94 \\
\hline & 3 & 45.59 & 0.22 & 32.85 & 2.29 & 24.28 & 1.806 & 23.61 & 0.71 & 23.80 & 0.35 & 24.38 & 0.65 \\
\hline & 6 & 51.08 & 0.35 & 39.15 & 1.65 & 38.35 & 3.539 & 38.93 & 1.02 & 37.28 & 1.93 & 36.37 & 2.01 \\
\hline & 10 & 48.15 & 0.19 & 9.74 & 1.82 & 8.85 & 2.083 & 7.73 & 2.85 & 3.21 & 1.55 & 1.95 & 0.97 \\
\hline & 17 & 45.28 & 0.49 & 8.64 & 3.96 & 6.49 & 1.918 & 7.18 & 1.06 & 5.13 & 0.29 & 4.15 & 2.17 \\
\hline \multirow{5}{*}{$\begin{array}{l}\text { Baked } \\
\text { Apatite II }\end{array}$} & $0^{1}$ & 45.04 & 0.27 & 0.67 & 0.18 & 0.9 & 0.369 & 2.02 & 1.12 & $2.39^{2}$ & 1.53 & 3.72 & 1.93 \\
\hline & 3 & 45.59 & 0.22 & 0.17 & 0.09 & 0.35 & 0.020 & 0.96 & 0.53 & 1.52 & 0.19 & 2.91 & 3.02 \\
\hline & 6 & 51.08 & 0.35 & 1.17 & 0.11 & 2.65 & 1.149 & 2.69 & 0.84 & 4.50 & 1.89 & 2.66 & 1.41 \\
\hline & 10 & 48.15 & 0.19 & 7.14 & 0.53 & 3.3 & 0.685 & 1.48 & 0.43 & 4.14 & 2.82 & 2.58 & 2.87 \\
\hline & 17 & 45.28 & 0.49 & 0.29 & 0.26 & 0.37 & 0.18 & 0.88 & 0.83 & 0.55 & 0.55 & 1.53 & 1.03 \\
\hline
\end{tabular}


Table A-7. Comparison of Mechanical and aged Baked Apatite II for removal of lead during semi-static sorption studies.

\begin{tabular}{|c|c|c|c|c|c|c|}
\hline Sample & Sample Time, days & $\operatorname{Rep} A$ & $\operatorname{Rep} B$ & Rep C & $\begin{array}{l}\text { Avg } \\
(n=3)\end{array}$ & Stdev \\
\hline \multirow{6}{*}{$\begin{array}{l}\text { Mechanical } \\
\text { Apatite II }\end{array}$} & Initial Conc. & & & & $47.721^{2}$ & 4.792 \\
\hline & $0^{1}$ & 3.786 & 5.803 & 3.730 & 4.440 & 1.181 \\
\hline & 3 & 36.640 & 35.880 & 37.260 & 36.593 & 0.691 \\
\hline & 6 & 39.180 & 39.250 & 28.600 & 35.677 & 6.129 \\
\hline & 10 & 0.336 & 0.351 & 1.304 & 0.664 & 0.555 \\
\hline & 17 & 2.171 & 2.626 & 1.922 & 2.240 & 0.357 \\
\hline \multirow{6}{*}{ Baked Apatite II } & Initial Conc. & & & & $47.721^{2}$ & 4.792 \\
\hline & $0^{1}$ & 0.175 & 0.240 & 0.405 & 0.273 & 0.119 \\
\hline & 3 & 0.339 & 0.462 & 0.429 & 0.410 & 0.064 \\
\hline & 6 & 1.486 & 4.118 & 3.521 & 3.042 & 1.380 \\
\hline & 10 & 0.563 & 0.797 & 1.001 & 0.787 & 0.219 \\
\hline & 17 & 0.204 & 0.143 & [6.113] & $2.153^{3}$ & 3.429 \\
\hline
\end{tabular}

Table A-8. Comparison of Mechanical and aged Baked Apatite II on removal of lead during semi-static sorption/settling studies.

\begin{tabular}{|c|c|c|c|c|c|c|}
\hline Sample & Sample Time, days & $\operatorname{Rep} A$ & $\operatorname{Rep~B}$ & Rep C & $\begin{array}{l}\text { Avg } \\
(n=3)\end{array}$ & Stdev \\
\hline \multirow{6}{*}{$\begin{array}{l}\text { Mechanical } \\
\text { Apatite II }\end{array}$} & Initial Conc. & & & & $47.721^{1}$ & 4.792 \\
\hline & $0+15$ Days & 1.983 & 1.843 & 1.733 & 1.853 & 0.125 \\
\hline & $3+15$ Days & 0.539 & 2.104 & 0.914 & 1.186 & 0.817 \\
\hline & $6+15$ Days & 2.274 & 2.003 & 3.114 & 2.464 & 0.579 \\
\hline & $10+15$ Days & 0.132 & 0.097 & 0.214 & 0.148 & 0.060 \\
\hline & $17+15$ Days & 1.435 & 0.754 & 0.446 & 0.878 & 0.506 \\
\hline \multirow{6}{*}{ Baked Apatite II } & Initial Conc. & & & & $47.721^{1}$ & 4.792 \\
\hline & $0+15$ Days & 0.411 & 0.896 & 0.813 & 0.706 & 0.259 \\
\hline & $3+15$ Days & 1.783 & 3.845 & [78.160] & $2.814^{2}$ & 1.458 \\
\hline & $6+15$ Days & 3.419 & 0.617 & 1.580 & 1.872 & 1.424 \\
\hline & $10+15$ Days & 0.154 & 0.665 & 0.897 & 0.572 & 0.380 \\
\hline & $17+15$ Days & 0.197 & 0.073 & 0.238 & 0.169 & 0.086 \\
\hline
\end{tabular}


Table A-9. Comparison of aged Baked Apatite II material removal of lead from solution during static sorption studies.

\begin{tabular}{|c|c|c|c|c|c|c|}
\hline \multirow[b]{3}{*}{ Day of Aging } & \multicolumn{6}{|c|}{ Soluble $\mathrm{Pb}$ Concentration, $\mathrm{mg} / \mathrm{L}$} \\
\hline & \multicolumn{2}{|c|}{ Enzymatic Apatite II } & \multicolumn{2}{|c|}{ Mechanical Apatite II } & \multicolumn{2}{|c|}{ Baked Apatite II } \\
\hline & $\begin{array}{l}\text { Avg } \\
(n=3)\end{array}$ & Stdev & $\begin{array}{l}\text { Avg } \\
(n=3)\end{array}$ & Stdev & $\begin{array}{l}\text { Avg } \\
(n=3)\end{array}$ & Stdev \\
\hline $\begin{array}{l}\text { Initial } \\
\text { Concentration }\end{array}$ & $57.108^{1}$ & 4.826 & $57.108^{1}$ & 4.826 & $57.108^{1}$ & 4.826 \\
\hline 1 & 1.884 & 0.818 & 1.497 & 1.006 & 0.018 & 0.004 \\
\hline 2 & 9.612 & 9.993 & 19.203 & 0.600 & $<0.038^{2}$ & 0.049 \\
\hline 3 & 35.217 & 4.386 & 18.783 & 4.386 & 0.296 & 0.023 \\
\hline 4 & 35.853 & 0.221 & 44.253 & 0.667 & $<0.010$ & 0.000 \\
\hline 5 & 40.060 & 1.312 & 45.560 & 0.017 & 0.741 & 0.065 \\
\hline 6 & 23.387 & 7.734 & 41.783 & 0.448 & 0.781 & 0.043 \\
\hline 7 & 1.164 & 0.634 & 30.107 & 0.634 & 0.335 & 0.082 \\
\hline 8 & 5.760 & 1.619 & 32.070 & 1.619 & 0.635 & 0.085 \\
\hline 9 & 12.388 & 6.039 & 0.320 & 0.210 & 1.128 & 0.139 \\
\hline 10 & 5.918 & 2.415 & 1.218 & 0.731 & 0.171 & 0.109 \\
\hline 14 & 0.878 & 0.186 & 17.587 & 7.297 & 0.632 & 0.092 \\
\hline 15 & 4.305 & 5.844 & 0.223 & 0.107 & $<0.044$ & 0.059 \\
\hline 16 & 3.119 & 0.182 & 0.449 & 0.326 & $<0.011$ & 0.003 \\
\hline 17 & 8.560 & 0.020 & 0.216 & 0.088 & $<0.032$ & 0.038 \\
\hline Average & 13.811 & 14.565 & 19.466 & 17.851 & $<0.372$ & 0.372 \\
\hline
\end{tabular}


Table A-10. Comparison of aged Baked Apatite II material on total lead concentration in solution following static sorption studies.

\begin{tabular}{|l|l|l|l|}
\hline \multirow{2}{*}{ Day of Aging } & \multicolumn{3}{|c|}{ Total Pb Concentration, mg/L } \\
\cline { 2 - 4 } & Enzymatic Apatite II & Mechanical Apatite II & Baked Apatite II \\
\hline Initial Concentration & 57.108 & 57.108 & 57.108 \\
\hline 1 & 38.62 & 22.58 & 30.67 \\
\hline 2 & 29.76 & 25.51 & 20.77 \\
\hline 3 & 35.6 & 35.63 & 18.55 \\
\hline 4 & 36.99 & 35.43 & 18.28 \\
\hline 5 & 39.84 & 39.97 & 31.75 \\
\hline 6 & 40.39 & 41.82 & 26.5 \\
\hline 7 & 37.95 & 35.44 & 13.5 \\
\hline 8 & 44.05 & 40.42 & 30.32 \\
\hline 9 & 41.47 & 53.24 & 18.2 \\
\hline 15 & 36.79 & 36.6 & 28.76 \\
\hline 16 & 41.41 & 46.34 & 27.77 \\
\hline Average $(\mathrm{n}=11)$ & 38.44 & 37.54 & 24.10 \\
\hline Std Dev & 3.79 & 8.59 & 6.36 \\
\hline
\end{tabular}




\section{Column study data}

Table A-11. Column study (saturated and intermittent columns) soluble lead concentrations.

\begin{tabular}{|c|c|c|c|c|c|c|c|c|c|c|c|c|c|c|c|c|c|c|}
\hline Wetting Event & 1 & 2 & 3 & 4 & 5 & 6 & 7 & 8 & 9 & 10 & 11 & 12 & 13 & 14 & 15 & 16 & & \\
\hline Amendment & \multicolumn{16}{|c|}{ Column Study I (Saturated) Pb Concentration in ppm } & Avg1 & Stc \\
\hline Clean Red River Sand & $<0.010$ & $<0.010$ & $<0.010$ & $<0.010$ & $<0.010$ & $<0.010$ & $<0.010$ & $<0.010$ & $<0.010$ & $<0.010$ & $<0.010$ & $<0.010$ & $<0.010$ & $<0.010$ & $<0.010$ & $<0.010$ & $<0.010$ & 0.000 \\
\hline Berm Red River Sand (no amendment) & 0.039 & 0.024 & 0.038 & 0.029 & 0.042 & 0.055 & 0.065 & 0.029 & 0.024 & 0.025 & 0.027 & 0.017 & 0.025 & 0.014 & 0.017 & 0.015 & 0.030 & 0.014 \\
\hline 5\% Mechanical Apatite II & 0.113 & 0.237 & 0.293 & 0.359 & 0.421 & 0.139 & 0.418 & 0.137 & 0.102 & 0.044 & 0.087 & 0.050 & 0.062 & 0.050 & 0.056 & 0.061 & 0.164 & 0.136 \\
\hline 5\% Enzymatic Apatite II & 0.317 & 0.318 & 0.441 & 0.086 & 0.052 & 0.062 & 0.212 & 0.312 & 0.296 & 0.214 & 0.135 & 0.047 & 0.018 & 0.042 & 0.049 & 0.050 & 0.166 & 0.135 \\
\hline $5 \%$ Baked Apatite II & 0.206 & 0.607 & 0.628 & 0.359 & 0.392 & 0.237 & 0.365 & 0.181 & 0.164 & 0.097 & 0.471 & 0.081 & 0.019 & 0.071 & 0.066 & 0.048 & 0.249 & 0.199 \\
\hline $5 \%$ Buffer Block \#5 & 0.028 & 0.056 & 0.050 & 0.132 & 0.137 & 0.058 & 0.086 & 0.087 & 0.069 & 0.069 & 0.069 & 0.131 & 0.098 & 0.091 & 0.079 & 0.103 & 0.084 & 0.031 \\
\hline $5 \%$ SulfiTechA/T & $<0.010$ & $<0.010$ & $<0.010$ & $<0.010$ & $<0.010$ & $<0.010$ & 0.024 & $<0.010$ & $<0.010$ & 0.025 & $<0.010$ & $<0.010$ & $<0.010$ & $<0.010$ & $<0.010$ & $<0.010$ & $<0.012$ & 0.005 \\
\hline Amendment & \multicolumn{16}{|c|}{ Column Study II (Intermittent) Pb Concentration in ppm } & Avg & Sto \\
\hline Clean Red River Sand & $<0.010$ & $<0.010$ & $<0.010$ & $<0.010$ & $<0.010$ & $<0.010$ & $<0.010$ & 0.055 & $<0.010$ & $<0.010$ & $<0.010$ & $<0.010$ & $<0.010$ & $<0.010$ & $<0.010$ & $<0.010$ & $<0.013$ & 0.011 \\
\hline $5 \%$ Mechanical Apatite II & 0.247 & n.d. ${ }^{2}$ & 1.136 & 0.471 & 0.449 & 0.082 & 0.091 & n.d. & n.d. & 0.013 & 0.014 & 0.026 & 0.053 & 0.019 & $<0.010$ & 0.022 & 0.202 & 0.324 \\
\hline 5\% Enzymatic Apatite II & 0.290 & 0.557 & 0.451 & 0.325 & 0.119 & 0.032 & 0.053 & 0.056 & 0.036 & 0.028 & 0.029 & 0.015 & 0.009 & 0.014 & 0.023 & 0.337 & 0.148 & 0.181 \\
\hline 5\% Baked Apatite II & $<0.010$ & $<0.010$ & $<0.010$ & $<0.010$ & $<0.010$ & $<0.010$ & $<0.010$ & n.d. & n.d. & $<0.010$ & $<0.010$ & $<0.010$ & $<0.010$ & $<0.010$ & 0.020 & $<0.010$ & $<0.011$ & 0.003 \\
\hline 5\% Buffer Block \#5 & $<0.010$ & $<0.010$ & $<0.010$ & $<0.010$ & $<0.010$ & $<0.010$ & $<0.010$ & n.d. & n.d. & $<0.010$ & 0.012 & 0.019 & 0.032 & 0.016 & $<0.010$ & $<0.010$ & $<0.013$ & 0.006 \\
\hline $5 \%$ SulfiTechA/T & 0.026 & $<0.010$ & $<0.010$ & $<0.010$ & $<0.010$ & $<0.010$ & $<0.010$ & 0.029 & $<0.010$ & $<0.010$ & $<0.010$ & $<0.010$ & $<0.010$ & $<0.010$ & $<0.010$ & $<0.010$ & $<0.012$ & 0.006 \\
\hline
\end{tabular}


Table A-12. Column study (saturated and intermittent columns) soluble copper concentrations.

\begin{tabular}{|c|c|c|c|c|c|c|c|c|c|c|c|c|c|c|c|c|c|c|}
\hline Wetting Event & 1 & 2 & 3 & 4 & 5 & 6 & 7 & 8 & 9 & 10 & 11 & 12 & 13 & 14 & 15 & 16 & & \\
\hline Amendment & \multicolumn{16}{|c|}{ Column Study I (Saturated) Pb Concentration in ppm } & Avg1 & Std \\
\hline Clean Red River Sand & $<0.010$ & $<0.010$ & $<0.010$ & $<0.010$ & $<0.010$ & $<0.010$ & $<0.010$ & $<0.010$ & $<0.010$ & $<0.010$ & $<0.010$ & $<0.010$ & $<0.010$ & $<0.010$ & $<0.010$ & $<0.010$ & 0.010 & 0.000 \\
\hline Berm Red River Sand (no amendment) & 0.017 & $<0.010$ & $<0.010$ & $<0.010$ & $<0.010$ & $<0.010$ & $<0.010$ & $<0.010$ & $<0.010$ & $<0.010$ & $<0.010$ & $<0.010$ & $<0.010$ & $<0.010$ & $<0.010$ & $<0.010$ & 0.010 & 0.002 \\
\hline 5\% Mechanical Apatite II & 0.711 & 0.786 & 2.567 & 1.511 & 1.526 & 0.490 & 0.188 & 0.070 & 0.031 & 0.016 & 0.010 & 0.012 & $<0.010$ & $<0.010$ & $<0.010$ & $<0.010$ & 0.497 & 0.759 \\
\hline 5\% Enzymatic Apatite II & 0.744 & 0.409 & 0.997 & 0.998 & 1.463 & 0.940 & 1.900 & 2.327 & 1.098 & 0.554 & 0.188 & 0.193 & 0.095 & 0.066 & 0.046 & 0.039 & 0.754 & 0.697 \\
\hline 5\% Baked Apatite II & 0.077 & 0.055 & 0.048 & 0.025 & 0.028 & 0.015 & 0.022 & $<0.010$ & $<0.010$ & $<0.010$ & 0.015 & $<0.010$ & $<0.010$ & $<0.010$ & $<0.010$ & $<0.010$ & 0.023 & 0.020 \\
\hline $5 \%$ Buffer Block \#5 & 0.035 & 0.024 & 0.014 & $<0.010$ & 0.012 & $<0.010$ & 0.012 & 0.004 & $<0.010$ & $<0.010$ & $<0.010$ & $<0.010$ & $<0.010$ & $<0.010$ & $<0.010$ & $<0.010$ & 0.013 & 0.007 \\
\hline $5 \%$ SulfiTechA/T & 0.062 & 0.020 & 0.017 & 0.011 & $<0.010$ & $<0.010$ & $<0.010$ & $<0.010$ & $<0.010$ & $<0.010$ & $<0.010$ & $<0.010$ & $<0.010$ & $<0.010$ & $<0.010$ & $<0.010$ & 0.014 & 0.013 \\
\hline Amendment & \multicolumn{16}{|c|}{ Column Study II (Intermittent) Pb Concentration in ppm } & Avg & Std \\
\hline Clean Red River Sand & $<0.010$ & $<0.010$ & $<0.010$ & $<0.010$ & $<0.010$ & $<0.010$ & $<0.010$ & $<0.010$ & $<0.010$ & $<0.010$ & $<0.010$ & $<0.010$ & $<0.010$ & $<0.010$ & $<0.010$ & $<0.010$ & $<0.010$ & 0.000 \\
\hline Berm Red River Sand (no amendment) & $<0.010$ & 0.091 & $<0.010$ & 0.022 & $<0.010$ & $<0.010$ & $<0.010$ & n.d. ${ }^{2}$ & n.d. & 0.034 & $<0.010$ & $<0.010$ & $<0.010$ & $<0.010$ & $<0.010$ & $<0.010$ & 0.018 & 0.022 \\
\hline $5 \%$ Mechanical Apatite II & 0.018 & 3.629 & 12.590 & 3.744 & 1.299 & 0.496 & 0.472 & n.d. & n.d. & 0.198 & 0.157 & 0.129 & 0.091 & 0.060 & 0.053 & 0.045 & 1.642 & 3.399 \\
\hline 5\% Enzymatic Apatite II & 0.091 & 0.258 & 0.100 & 0.075 & 0.048 & 0.103 & 0.117 & 0.237 & 0.120 & 0.141 & 0.129 & 0.091 & 0.057 & 0.078 & 0.110 & 0.118 & 0.117 & 0.057 \\
\hline 5\% Baked Apatite II & $<0.010$ & $<0.010$ & 0.086 & $<0.010$ & $<0.010$ & $<0.010$ & $<0.010$ & n.d. & n.d. & $<0.010$ & $<0.010$ & $<0.010$ & $<0.010$ & $<0.010$ & $<0.010$ & $<0.010$ & 0.015 & 0.020 \\
\hline $5 \%$ Buffer Block \#5 & $<0.010$ & $<0.010$ & $<0.010$ & $<0.010$ & $<0.010$ & $<0.010$ & $<0.010$ & n.d. & n.d. & $<0.010$ & $<0.010$ & $<0.010$ & $<0.010$ & $<0.010$ & $<0.010$ & $<0.010$ & 0.013 & 0.010 \\
\hline $5 \%$ SulfiTechA/T & $<0.010$ & $<0.010$ & $<0.010$ & $<0.010$ & $<0.010$ & $<0.010$ & $<0.010$ & 0.014 & $<0.010$ & $<0.010$ & $<0.010$ & $<0.010$ & $<0.010$ & $<0.010$ & $<0.010$ & $<0.010$ & $<0.010$ & 0.001 \\
\hline
\end{tabular}


Table A-13. Column study soluble lead and copper in leachate from columns using the same columns for each study.

\begin{tabular}{|c|c|c|c|c|c|c|c|}
\hline \multirow[b]{2}{*}{ Sand } & \multirow[b]{2}{*}{ Amendment } & \multicolumn{3}{|c|}{$\begin{array}{l}\text { Filtered } \mathrm{Pb} \text { Leaving the Column } \\
\text { mg }\end{array}$} & \multicolumn{3}{|c|}{$\begin{array}{l}\text { Filtered Cu Leaving the Column } \\
\text { mg }\end{array}$} \\
\hline & & $\begin{array}{l}\text { Phase I } \\
\text { Saturated }^{1}\end{array}$ & $\begin{array}{l}\text { Phase II } \\
\text { Intermittent }{ }^{2}\end{array}$ & Total & $\begin{array}{l}\text { Phase I } \\
\text { Saturated }\end{array}$ & $\begin{array}{l}\text { Phase II } \\
\text { Intermittent }\end{array}$ & Total \\
\hline $\begin{array}{l}\text { Clean Red } \\
\text { River Sand }\end{array}$ & None & $<0.019^{3}$ & $<0.015$ & 0.034 & $<0.018$ & $<0.017$ & 0.035 \\
\hline \multirow{6}{*}{$\begin{array}{l}\text { Berm Red } \\
\text { River Sand }\end{array}$} & None & 0.058 & $<0.024$ & 0.082 & $<0.019$ & $<0.018$ & 0.037 \\
\hline & 5\% Mechanical Apatite II & 0.307 & $<0.213$ & 0.520 & $<0.917$ & 1.642 & 2.559 \\
\hline & 5\% Enzymatic Apatite II & 0.301 & $<0.183$ & 0.484 & 1.383 & 0.114 & 1.497 \\
\hline & 5\% Baked Apatite II & 0.470 & $<0.016$ & 0.486 & $<0.043$ & $<0.015$ & 0.058 \\
\hline & 5\% Buffer Block \#5 & 0.156 & $<0.019$ & 0.175 & $<0.023$ & $<0.013$ & 0.036 \\
\hline & $5 \%$ SulfiTech A/T & $<0.022$ & $<0.007$ & 0.029 & $<0.027$ & $<0.01$ & 0.037 \\
\hline
\end{tabular}

1 Saturated column wetting events two times per day.

2 Wetting and drying cycles allowed in column by wetting events occurring once per week.

3 IDL used in calculations.

\section{Lysimeter Study II data}

Table A-14. Lysimeter Study II digested lead and copper in leachate and runoff over 16 rain events. ${ }^{1}$

\begin{tabular}{|c|c|c|c|c|c|c|c|}
\hline \multirow[b]{2}{*}{ Sand } & \multirow[b]{2}{*}{ Amendment } & \multicolumn{3}{|c|}{$\begin{array}{l}\text { Digested } \mathrm{Pb} \text { leaving the } \\
\text { Lysimeter, mg }\end{array}$} & \multicolumn{3}{|c|}{$\begin{array}{l}\text { Digested Cu Leaving the } \\
\text { Lysimeter, mg }\end{array}$} \\
\hline & & Leachate & Runoff & Total & Leachate & Runoff & Total \\
\hline \multirow{8}{*}{$\begin{array}{l}\text { Berm Red } \\
\text { River Sand }\end{array}$} & Control - No Amendment & 5.79 & 35.53 & 41.31 & 0.21 & 0.81 & 1.01 \\
\hline & 5\% Baked Apatite II & 21.12 & 14.64 & 35.75 & 1.40 & 0.28 & 1.68 \\
\hline & 5\% Enzymatic Apatite II & 42.49 & 55.83 & 98.32 & 345.00 & 3.09 & 348.09 \\
\hline & 5\% Mechanical Apatite II & 51.27 & 36.80 & 88.07 & 608.41 & 1.67 & 610.08 \\
\hline & $5 \%$ SulfiTech A/T & 4.67 & 30.26 & 34.93 & 0.64 & 0.71 & 1.35 \\
\hline & 1\% Buffer Block \#5 & 4.94 & 9.12 & 14.06 & 0.31 & 0.36 & 0.67 \\
\hline & 3\% Buffer Block \#5 & 1.80 & 47.95 & 49.75 & 0.18 & 1.32 & 1.50 \\
\hline & 5\% Buffer Block \#5 & 2.90 & 11.59 & 14.49 & 0.22 & 0.51 & 0.73 \\
\hline
\end{tabular}


Table A-15. Lysimeter Study II soluble lead and copper in leachate and runoff over 16 rain events. ${ }^{1}$

\begin{tabular}{|l|l|l|l|l|l|l|l|}
\hline \multirow{4}{*}{ Sand } & \multirow{2}{*}{ Amendment } & \multicolumn{3}{|c|}{ Soluble Pb Leaving the Lysimeter } & \multicolumn{3}{|c|}{ Soluble Cu Leaving the Lysimeter } \\
mg
\end{tabular}

Table A-16. Lysimeter Study II average $(n=16)$ soluble metals concentration in runoff.

\begin{tabular}{|l|l|l|l|l|l|l|l|l|}
\hline \multirow{2}{*}{ Lysimeter Cell } & \multicolumn{7}{|c|}{ Average Runoff Soluble Metal Concentration (n=16), mg/L } \\
\cline { 2 - 9 } & $\mathrm{Cr}$ & $\mathrm{Ni}$ & $\mathrm{Zn}$ & $\mathrm{Fe}$ & $\mathrm{Mn}$ & $\mathrm{Mo}$ & $\mathrm{V}$ & $\mathrm{Sb}$ \\
\hline Unamended Sand & $<0.010^{1}$ & $<0.010$ & $<0.010$ & $<0.025$ & $<0.010$ & $<0.010$ & $<0.010$ & 0.046 \\
\hline 5\% Baked Apatite II & $<0.010$ & $<0.010$ & $<0.010$ & $<0.018$ & $<0.010$ & $<0.010$ & $<0.011$ & 0.088 \\
\hline $\begin{array}{l}5 \% \text { Enzymatic } \\
\text { Apatite II }\end{array}$ & $<0.010$ & $<0.010$ & $<0.010$ & $<0.070$ & $<0.010$ & $<0.010$ & $<0.011$ & 0.101 \\
\hline $\begin{array}{l}\text { 5\% Mechanical } \\
\text { Apatite II }\end{array}$ & $<0.010$ & $<0.010$ & $<0.010$ & $<0.038$ & $<0.011$ & $<0.010$ & $<0.011$ & 0.079 \\
\hline 5\% SulfiTech & $<0.010$ & $<0.010$ & $<0.011$ & $<0.010$ & $<0.010$ & $<0.010$ & $<0.011$ & 0.040 \\
\hline 1\% Buffer Block \#5 & $<0.010$ & $<0.010$ & $<0.010$ & $<0.019$ & $<0.010$ & $<0.010$ & $<0.011$ & 0.026 \\
\hline 3\% Buffer Block \#5 & $<0.010$ & $<0.010$ & $<0.010$ & $<0.014$ & $<0.010$ & $<0.010$ & $<0.011$ & 0.070 \\
\hline 5\% Buffer Block \#5 & $<0.010$ & $<0.010$ & $<0.010$ & $<0.017$ & $<0.010$ & $<0.010$ & $<0.011$ & 0.034 \\
\hline 1 IDL used in calculations. & & & & & & \\
\hline
\end{tabular}


Table A-17. Lysimeter Study II average $(n=16)$ digested metals concentration in runoff.

\begin{tabular}{|l|l|l|l|l|l|l|l|l|}
\hline \multirow{2}{*}{ Lysimeter Cell } & \multicolumn{7}{|c|}{ Average Runoff Digested Metal Concentration (n=16), mg/L } \\
\cline { 2 - 9 } & $\mathrm{Cr}$ & $\mathrm{Ni}$ & $\mathrm{Zn}$ & $\mathrm{Fe}$ & $\mathrm{Mn}$ & $\mathrm{Mo}$ & $\mathrm{V}$ & $\mathrm{Sb}$ \\
\hline Unamended Sand & $<0.010$ & $<0.010$ & $<0.021$ & 0.182 & $<0.030$ & $<0.010$ & $<0.011$ & 0.057 \\
\hline 5\% Baked Apatite II & $<0.010$ & $<0.010$ & $<0.028$ & 0.067 & $<0.012$ & $<0.010$ & $<0.011$ & 0.070 \\
\hline $\begin{array}{l}5 \% \text { Enzymatic } \\
\text { Apatite II }\end{array}$ & $<0.010$ & $<0.010$ & $<0.031$ & 0.278 & $<0.058$ & $<0.010$ & $<0.011$ & 0.106 \\
\hline $\begin{array}{l}5 \% \text { Mechanical } \\
\text { Apatite II }\end{array}$ & $<0.010$ & $<0.010$ & $<0.024$ & 0.175 & $<0.052$ & $<0.010$ & $<0.011$ & 0.074 \\
\hline 5\% SulfiTech & $<0.010$ & $<0.010$ & $<0.021$ & 0.177 & $<0.032$ & $<0.010$ & $<0.012$ & 0.046 \\
\hline 1\% Buffer Block \#5 & $<0.010$ & $<0.010$ & $<0.013$ & 0.090 & $<0.013$ & $<0.010$ & $<0.011$ & 0.028 \\
\hline 3\% Buffer Block \#5 & $<0.010$ & $<0.010$ & $<0.027$ & 0.550 & 0.052 & $<0.010$ & $<0.012$ & 0.098 \\
\hline 5\% Buffer Block \#5 & $<0.010$ & $<0.010$ & $<0.024$ & 0.170 & $<0.018$ & $<0.010$ & $<0.011$ & 0.039 \\
\hline 1 IDL used in calculations. & & & & & & \\
\hline
\end{tabular}

Table A-18. Lysimeter Study II amended soil pH for pre- and post-study.

\begin{tabular}{|l|l|l|}
\hline Amendment & Pre-pH & Post-pH \\
\hline Unamended Sand & 9.14 & 8.48 \\
\hline 5\% Baked Apatite II & 9.29 & 8.64 \\
\hline 5\% Enzymatic Apatite II & 9.02 & 8.49 \\
\hline 5\% Mechanical Apatite II & 8.24 & 7.98 \\
\hline 5\% SulfiTech & 9.16 & 8.37 \\
\hline 1\% Buffer Block \#5 & 9.39 & 9.15 \\
\hline 3\% Buffer Block \#5 & 8.83 & 8.67 \\
\hline 5\% Buffer Block \#5 & 9.02 & 9.14 \\
\hline
\end{tabular}


Table A-19. Lysimeter Study II pH values of leachate and runoff water. (Highlighted cells did not meet objectives.)

\begin{tabular}{|c|c|c|c|c|c|c|c|c|c|c|c|c|c|c|c|c|c|c|}
\hline Rain Event & 1 & 2 & 3 & 4 & 5 & 6 & 7 & 8 & 9 & 10 & 11 & 12 & 13 & 14 & 15 & 16 & & \\
\hline \multicolumn{19}{|c|}{ Leachate } \\
\hline Amendment & \multicolumn{16}{|c|}{ Observed pH } & Avg & Std \\
\hline Control - No amendment & 8.24 & 8.14 & 6.96 & 7.72 & 7.11 & 7.21 & 7.83 & 7.86 & 7.80 & 7.74 & 6.70 & 7.22 & 7.01 & 7.01 & 7.32 & 7.54 & 7.46 & 0.46 \\
\hline 5\% Baked Apatite II & 8.77 & 8.27 & 7.71 & 8.24 & 8.04 & 7.90 & 8.08 & 8.14 & 7.99 & 7.92 & 7.50 & 8.05 & 7.15 & 7.82 & 7.81 & 8.08 & 7.97 & 0.35 \\
\hline 5\% Enzymatic Apatite II & 8.42 & 8.25 & 8.50 & 8.59 & 8.83 & 8.96 & 8.80 & 8.93 & $9.02^{1}$ & 8.91 & 8.90 & 8.94 & 8.92 & 8.87 & 8.80 & 8.86 & 8.78 & 0.22 \\
\hline 5\% Mechanical Apatite II & 8.01 & 8.24 & 8.49 & 8.65 & 8.79 & 8.89 & 8.79 & 8.93 & 8.96 & 8.83 & 8.84 & 8.91 & 8.85 & 8.78 & 8.69 & 8.69 & 8.71 & 0.26 \\
\hline $5 \%$ SulfiTech & 8.15 & 7.45 & 6.80 & 7.28 & 7.20 & 7.31 & 7.44 & 7.44 & 7.29 & 7.29 & 7.25 & 7.25 & 6.54 & 7.06 & 7.25 & 7.40 & 7.28 & 0.34 \\
\hline 1\% Buffer Block\#5 & 8.30 & 7.90 & 7.53 & 7.88 & 7.77 & 7.68 & 8.05 & 7.89 & 7.79 & 7.85 & 7.83 & 7.93 & 7.57 & 7.75 & 7.87 & 8.04 & 7.85 & 0.19 \\
\hline 3\% Buffer Block\#5 & 8.06 & 7.48 & 7.14 & 7.64 & 7.65 & 7.70 & 7.87 & 7.82 & 7.86 & 7.81 & 7.92 & 8.02 & 7.35 & 7.84 & 7.83 & 8.04 & 7.75 & 0.25 \\
\hline 5\% Buffer Block\#5 & 8.21 & 7.76 & 7.38 & 7.87 & 7.67 & 7.74 & 8.04 & 7.87 & 7.84 & 7.93 & 7.96 & 8.01 & 7.61 & 7.98 & 8.02 & 8.25 & 7.88 & 0.22 \\
\hline RO Water & 7.59 & 5.81 & 6.43 & 5.78 & 5.90 & 6.14 & 5.77 & 5.60 & 5.84 & n.d. ${ }^{2}$ & n.d. & n.d. & n.d. & n.d. & n.d. & n.d. & 6.10 & 0.61 \\
\hline \multicolumn{19}{|c|}{ Runoff } \\
\hline Amendment & \multicolumn{16}{|c|}{ Observed $\mathrm{pH}$} & Avg & Std \\
\hline Control - No amendment & 7.99 & 8.02 & 6.35 & 7.12 & 7.13 & 6.91 & 7.59 & 7.12 & 6.28 & 6.80 & 6.96 & 7.09 & 6.62 & 6.24 & 6.95 & 6.82 & 7.00 & 0.53 \\
\hline 5\% Baked Apatite II & 7.69 & 7.38 & 6.65 & 7.31 & 7.44 & 6.48 & 7.52 & 7.15 & 6.33 & 6.37 & 6.59 & 6.48 & 6.51 & 6.39 & 6.93 & 7.08 & 6.89 & 0.47 \\
\hline 5\% Enzymatic Apatite II & 7.62 & 6.92 & 5.98 & 7.00 & 6.79 & 6.70 & 7.74 & 7.67 & 7.03 & 6.74 & 6.94 & 7.00 & 5.96 & 6.31 & 6.92 & 6.70 & 6.88 & 0.52 \\
\hline 5\% Mechanical Apatite II & 7.44 & 6.40 & 6.35 & 6.71 & 6.14 & 6.03 & 6.63 & 6.31 & 6.15 & 6.28 & 6.30 & 6.26 & 5.79 & 6.06 & 6.45 & 6.34 & 6.35 & 0.37 \\
\hline $5 \%$ SulfiTech & 9.67 & 8.41 & 7.23 & 6.93 & 8.02 & 7.50 & 7.46 & 6.78 & 6.69 & 7.99 & 7.03 & 7.77 & 8.03 & 7.27 & 8.02 & 7.44 & 7.64 & 0.74 \\
\hline 1\% Buffer Block\#5 & 9.60 & 8.21 & 6.46 & 6.92 & 7.15 & 6.69 & 6.92 & 6.90 & 6.79 & 7.02 & 6.67 & 6.93 & 6.92 & 6.57 & 6.83 & 6.74 & 7.08 & 0.77 \\
\hline 3\% Buffer Block\#5 & 9.85 & 9.52 & 8.95 & 9.02 & 9.19 & 8.88 & 9.44 & 9.48 & 9.39 & 9.40 & 9.12 & 9.43 & 9.47 & 9.48 & 9.30 & 9.34 & 9.33 & 0.25 \\
\hline 5\% Buffer Block\#5 & 9.91 & 9.51 & 7.49 & 7.69 & 8.26 & 9.62 & 8.78 & 8.24 & 8.09 & 7.70 & 7.07 & 7.16 & 7.26 & 7.54 & 7.46 & 7.30 & 8.07 & 0.92 \\
\hline
\end{tabular}


Table A-20. Lysimeter Study II Total Suspended Solids ${ }^{1}$ in leachate and runoff.

\begin{tabular}{|c|c|c|c|c|c|c|c|c|c|c|c|c|c|c|c|c|}
\hline Rain Event & 1 & 2 & 3 & 4 & 5 & 6 & 7 & 8 & 9 & 10 & 11 & 12 & 13 & 14 & 15 & 16 \\
\hline Amendment & \multicolumn{16}{|c|}{ Leachate TSS } \\
\hline Control - Unamended Sand & 0.3 & 0.2 & 0.3 & 0.7 & 11.0 & 3.2 & 2.1 & n.d. ${ }^{2}$ & 0.8 & 0.7 & 1.1 & n.d. & 0.5 & n.d. & n.d. & n.d. \\
\hline 5\% Baked Apatite II & 37.9 & 26.7 & 18.6 & 32.9 & 17.6 & 15.2 & 23.4 & n.d. & 10.1 & 10.2 & 5.9 & n.d. & 6.3 & 1.3 & n.d. & n.d. \\
\hline 5\% Enzymatic Apatite II & 50.3 & 75.1 & 61.3 & 27.1 & 20.5 & 15.4 & 14.4 & n.d. & 4.8 & 5.7 & 5.6 & n.d. & 6.7 & n.d. & n.d. & n.d. \\
\hline 5\% Mechanical Apatite II & 103.9 & 125.5 & 51.4 & 52.4 & 34.5 & 30.8 & 28.7 & n.d. & 15.0 & 15.9 & 10.7 & n.d. & 5.8 & n.d. & n.d. & n.d. \\
\hline $5 \%$ SulfiTech & 1.7 & 0.9 & 1.3 & 0.6 & 1.0 & 2.3 & 2.5 & n.d. & 0.6 & 1.2 & 0.7 & n.d. & 1.1 & n.d. & n.d. & n.d. \\
\hline 1\% Buffer Block\#5 & 1.0 & 0.2 & 1.4 & 1.9 & 2.5 & 1.5 & 1.5 & n.d. & 1.2 & 1.4 & 1.2 & n.d. & 1.1 & n.d. & n.d. & n.d. \\
\hline 3\% Buffer Block\#5 & 0.4 & 1.5 & 0.8 & 0.6 & 1.9 & 1.2 & 0.4 & n.d. & 0.9 & 1.1 & 1.3 & n.d. & 0.9 & n.d. & n.d. & n.d. \\
\hline 5\% Buffer Block\#5 & 0.5 & 0.4 & 0.8 & 1.1 & 2.0 & 2.0 & 2.7 & n.d. & 0.7 & 1.5 & 1.3 & n.d. & 1.9 & n.d. & n.d. & n.d. \\
\hline Amendment & \multicolumn{16}{|c|}{ Runoff TSS } \\
\hline Control - Unamended Sand & 17.1 & 12.7 & 11.0 & 18.1 & 7.3 & 6.5 & 9.4 & n.d. & 5.8 & 4.4 & 5.5 & n.d. & 1.8 & n.d. & n.d. & n.d. \\
\hline 5\% Baked Apatite II & 7.2 & 0.9 & 3.3 & 0.6 & 3.5 & 1.2 & 1.5 & n.d. & 1.9 & 1.3 & 1.4 & n.d. & 1.4 & n.d. & n.d. & n.d. \\
\hline 5\% Enzymatic Apatite II & 80.8 & 34.8 & 34.1 & 40.7 & 15.6 & 6.3 & 18.2 & n.d. & 6.8 & 3.5 & 2.6 & n.d. & 2.0 & n.d. & n.d. & n.d. \\
\hline 5\% Mechanical Apatite II & 93.0 & 9.5 & 30.7 & 53.2 & 10.7 & 7.2 & 16.4 & n.d. & 6.4 & 3.8 & 6.2 & n.d. & 5.0 & n.d. & n.d. & n.d. \\
\hline $5 \%$ SulfiTech & 149.5 & 5.2 & 1.9 & 2.1 & 2.0 & 1.0 & 1.0 & n.d. & 1.2 & 1.2 & 0.3 & n.d. & 1.0 & n.d. & n.d. & n.d. \\
\hline 1\% Buffer Block\#5 & 15.2 & 0.2 & 0.4 & 0.7 & 2.5 & 0.4 & 2.0 & n.d. & 1.2 & 1.5 & 1.2 & n.d. & 1.2 & n.d. & n.d. & n.d. \\
\hline 3\% Buffer Block\#5 & 61.8 & 82.4 & 35.1 & 42.1 & 13.5 & 5.7 & 24.0 & n.d. & 10.3 & 7.1 & 6.7 & n.d. & 5.5 & n.d. & n.d. & n.d. \\
\hline 5\% Buffer Block\#5 & 17.8 & 1.0 & 4.7 & 0.6 & 0.8 & 24.3 & 0.8 & n.d. & 1.4 & 1.1 & 0.8 & n.d. & 1.5 & n.d. & n.d. & n.d. \\
\hline \multicolumn{17}{|c|}{$\begin{array}{l}1 \text { TSS determined from a } 200-\mathrm{mL} \text { sample of leachate and runoff. } \\
2 \text { n.d. = not determined }\end{array}$} \\
\hline
\end{tabular}


Table A-21. Lysimeter Study II volume of leachate and runoff water collected.

\begin{tabular}{|c|c|c|c|c|c|c|c|c|c|c|c|c|c|c|c|c|c|c|c|}
\hline Rain Event & 1 & 2 & 3 & 4 & 5 & 6 & 7 & 8 & 9 & 10 & 11 & 12 & 13 & 14 & 15 & 16 & $\begin{array}{c}\text { Avg } \\
n=16\end{array}$ & Std & Total $^{3}$ \\
\hline \multicolumn{20}{|c|}{ Leachate } \\
\hline Amendment & \multicolumn{16}{|c|}{ Volume Water Collected } & & & \\
\hline Control - Unamended Sand & 1.815 & 1.054 & 1.343 & 0.597 & 0.708 & 1.104 & 1.133 & 1.237 & 1.010 & 0.913 & 0.727 & 0.812 & 1.182 & 1.034 & 1.314 & 1.351 & 1.083 & 0.303 & 17.33 \\
\hline 5\% Baked Apatite II & 2.115 & 1.837 & 1.789 & 1.444 & 1.948 & 1.259 & 1.512 & 1.601 & 1.462 & 1.604 & 1.385 & 1.460 & 1.338 & 1.308 & 1.478 & 1.419 & 1.560 & 0.243 & 24.96 \\
\hline 5\% Enzymatic Apatite II & 2.113 & 1.498 & 1.623 & 1.407 & 1.259 & 1.404 & 1.605 & 1.502 & 1.540 & 1.550 & 1.686 & 1.657 & 1.508 & 1.478 & 1.614 & 1.651 & 1.568 & 0.183 & 25.10 \\
\hline 5\% Mechanical Apatite II & 1.965 & 1.005 & 2.149 & 1.858 & 1.692 & 1.627 & 1.764 & 1.773 & 1.639 & 1.780 & 1.844 & 1.403 & 1.601 & 1.658 & 1.747 & 1.793 & 1.706 & 0.250 & 27.30 \\
\hline $5 \%$ SulfiTech & 1.853 & 1.015 & 1.106 & 0.997 & 0.779 & 0.530 & 0.860 & 1.190 & 1.051 & 1.237 & 1.130 & 0.848 & 1.138 & 1.236 & 1.395 & 1.189 & 1.097 & 0.292 & 17.55 \\
\hline 1\% Buffer Block\#5 & 1.861 & 2.290 & 1.545 & 1.180 & 1.256 & 1.036 & 1.301 & 1.433 & 1.106 & 1.190 & 1.204 & 1.118 & 1.121 & 1.092 & 1.300 & 1.164 & 1.325 & 0.330 & 21.20 \\
\hline 3\% Buffer Block\#5 & 1.998 & 0.963 & 1.154 & 1.176 & 0.713 & 0.870 & 1.315 & 1.221 & 0.988 & 1.181 & 1.125 & 0.656 & 1.080 & 1.043 & 1.187 & 1.063 & 1.108 & 0.297 & 17.73 \\
\hline 5\% Buffer Block\#5 & 1.449 & 0.837 & 1.216 & 0.740 & 0.646 & 0.777 & 0.905 & 0.988 & 0.848 & 0.840 & 0.978 & 1.007 & 0.952 & 0.973 & 1.087 & 1.102 & 0.959 & 0.195 & 15.35 \\
\hline \multicolumn{20}{|c|}{ Runoff } \\
\hline Control - Unamended Sand & 1.681 & 1.683 & 1.687 & 1.630 & 1.839 & 1.623 & 1.679 & 1.678 & 1.611 & 1.614 & 1.670 & 1.865 & 1.686 & 1.747 & 1.720 & 1.595 & 1.688 & 0.076 & 27.01 \\
\hline 5\% Baked Apatite II & 1.437 & 1.118 & 1.240 & 1.313 & 1.697 & 1.216 & 1.255 & 1.395 & 1.264 & 1.212 & 1.309 & 1.417 & 1.420 & 1.433 & 1.490 & 1.403 & 1.351 & 0.139 & 21.62 \\
\hline 5\% Enzymatic Apatite II & 1.577 & 1.670 & 1.745 & 1.686 & 1.903 & 1.791 & 1.578 & 1.700 & 1.611 & 1.550 & 1.486 & 1.508 & 1.618 & 1.556 & 1.595 & 1.489 & 1.629 & 0.115 & 26.06 \\
\hline 5\% Mechanical Apatite II & 1.622 & 1.939 & 1.496 & 1.354 & 1.527 & 1.698 & 1.495 & 1.478 & 1.556 & 1.369 & 1.325 & 1.837 & 1.615 & 1.547 & 1.550 & 1.466 & 1.555 & 0.164 & 24.87 \\
\hline $5 \%$ SulfiTech & 1.677 & 1.666 & 1.920 & 1.694 & 1.832 & 2.096 & 1.804 & 1.682 & 1.676 & 1.585 & 1.684 & 1.957 & 1.637 & 1.412 & 1.552 & 1.560 & 1.715 & 0.171 & 27.43 \\
\hline 1\% Buffer Block\#5 & 1.626 & 1.615 & 1.353 & 1.440 & 1.316 & 1.549 & 1.490 & 1.400 & 1.527 & 1.496 & 1.505 & 1.597 & 1.571 & 1.451 & 1.532 & 1.483 & 1.497 & 0.089 & 23.95 \\
\hline 3\% Buffer Block\#5 & 1.602 & 1.660 & 1.675 & 1.352 & 1.713 & 1.722 & 1.322 & 1.589 & 1.664 & 1.508 & 1.573 & 1.951 & 1.552 & 1.464 & 1.569 & 1.566 & 1.593 & 0.149 & 25.48 \\
\hline 5\% Buffer Block\#5 & 2.027 & 1.714 & 1.717 & 1.644 & 1.786 & 1.721 & 1.661 & 1.708 & 1.709 & 1.764 & 1.640 & 1.643 & 1.658 & 1.538 & 1.781 & 1.522 & 1.702 & 0.115 & 27.23 \\
\hline
\end{tabular}


Table A-22. Lysimeter Study II Dissolved Organic Carbon ( $<0.45$ micron) in runoff and leachate waters.

\begin{tabular}{|c|c|c|c|c|c|c|c|c|c|c|c|c|c|c|c|c|c|c|}
\hline Rain Event & 1 & 2 & 3 & 4 & 5 & 6 & 7 & 8 & 9 & 10 & 11 & 12 & 13 & 14 & 15 & 16 & Avg & Std \\
\hline \multicolumn{19}{|c|}{ Leachate } \\
\hline Amendment & \multicolumn{16}{|c|}{$\mathrm{DOC}, \mathrm{mg} / \mathrm{L}$} & & \\
\hline Control - No amendment & 2.7 & 3.3 & 215.6 & 185.1 & 77.1 & 4.2 & 2.1 & 2.0 & 2.8 & 1.9 & 21.6 & 340.3 & 265.2 & 47.3 & 14.8 & 2.2 & 74.3 & 111.8 \\
\hline 5\% Baked Apatite II & 5.1 & 2.7 & 0.8 & 2.5 & 4.6 & 6.6 & 5.2 & 3.4 & 4.2 & 3.1 & 3.5 & 2.5 & 2.1 & 2.6 & 2.9 & 1.9 & 3.4 & 1.5 \\
\hline 5\% Enzymatic Apatite II & 359.8 & 1797.0 & 577.2 & 339.4 & 339.0 & 246.0 & 176.3 & 120.8 & 75.7 & 84.0 & 68.4 & 39.3 & 44.5 & 41.5 & 36.0 & 31.1 & 273.5 & 436.4 \\
\hline 5\% Mechanical Apatite II & 818.4 & 550.4 & 556.4 & 1636.0 & 1222.0 & 224.8 & 183.9 & 140.7 & 95.1 & 82.2 & 60.3 & 40.0 & 35.0 & 26.2 & 21.8 & 18.9 & 357.0 & 485.9 \\
\hline $5 \%$ SulfiTech & 7.8 & 7.9 & 6.0 & 4.0 & 3.7 & 0.9 & 1.9 & 1.7 & 3.1 & 1.7 & 1.6 & 1.7 & 1.7 & 1.2 & 1.4 & 1.9 & 3.0 & 2.3 \\
\hline 1\% Buffer Block\#5 & 3.1 & 2.8 & 4.6 & 3.4 & 2.6 & 2.9 & 1.7 & 1.9 & 2.9 & 0.9 & 1.6 & 1.6 & 1.4 & 0.9 & 0.4 & 1.4 & 2.1 & 1.1 \\
\hline 3\% Buffer Block\#5 & 3.1 & 5.0 & 4.2 & 3.2 & 2.6 & 2.1 & 1.5 & 1.3 & 12.8 & 0.5 & 0.6 & n.d. ${ }^{1}$ & 0.6 & 0.1 & 0.6 & 1.5 & 2.7 & 3.2 \\
\hline 5\% Buffer Block\#5 & 4.5 & 5.1 & 3.5 & 3.5 & 3.3 & 2.7 & 2.0 & 1.8 & 2.5 & 1.4 & 1.2 & 0.5 & 0.1 & 0.5 & n.d. & 3.8 & 2.4 & 1.5 \\
\hline RO Water & 2.7 & 3.3 & 215.6 & 185.1 & 77.1 & 4.2 & 2.1 & 2.0 & 2.8 & 1.9 & 21.6 & 340.3 & 265.2 & 47.3 & 14.8 & 2.2 & 74.3 & 111.8 \\
\hline \multicolumn{19}{|c|}{ Runoff } \\
\hline Control - No amendment & 1.1 & 0.8 & 236.8 & 2.1 & 0.6 & 32.7 & 8.5 & 0.7 & 1.2 & 0.7 & n.d. & 0.7 & 25.8 & 0.8 & 0.8 & 3.1 & 21.1 & 60.5 \\
\hline 5\% Baked Apatite II & 1.0 & 0.7 & 19.5 & 0.9 & 0.9 & 2.4 & 0.5 & 0.5 & 1.1 & 0.6 & n.d. & 0.5 & 4.4 & 0.6 & 1.2 & 0.4 & 2.3 & 4.9 \\
\hline 5\% Enzymatic Apatite II & 1.4 & 2.2 & 2.7 & 3.8 & 2.4 & 2.4 & 1.7 & 2.1 & 1.8 & 1.3 & n.d. & 0.7 & 3.2 & 0.7 & 0.7 & 1.1 & 1.9 & 0.9 \\
\hline 5\% Mechanical Apatite II & 6.3 & 2.6 & 5.0 & 4.2 & 2.9 & 1.9 & 1.4 & 1.5 & 1.7 & 1.0 & n.d. & 0.7 & 1.5 & 0.6 & 2.2 & 0.1 & 2.2 & 1.7 \\
\hline 5\% SulfiTech & 0.9 & 0.5 & 6.4 & 0.5 & 1.1 & 1.1 & 0.6 & 0.9 & 2.5 & 0.4 & n.d. & 0.3 & 3.7 & 1.6 & 1.9 & n.d. & 1.6 & 1.7 \\
\hline 1\% Buffer Block\#5 & 0.8 & 0.5 & 4.5 & n.d. & 0.6 & 1.3 & 0.5 & 0.8 & 1.4 & 0.3 & n.d. & 0.4 & 3.0 & 0.4 & 0.4 & 3.1 & 1.3 & 1.3 \\
\hline 3\% Buffer Block\#5 & 1.1 & 0.5 & 3.2 & 0.7 & 0.8 & 1.0 & 0.5 & 0.7 & 1.0 & 0.7 & n.d. & 0.2 & 2.4 & 0.3 & n.d. & 0.8 & 1.0 & 0.8 \\
\hline 5\% Buffer Block\#5 & 0.6 & 0.5 & 2.8 & 0.9 & 1.0 & 1.0 & 0.4 & 0.8 & 1.0 & 0.3 & 0.8 & 0.4 & 2.6 & 0.4 & 0.9 & 0.9 & 1.0 & 0.7 \\
\hline
\end{tabular}




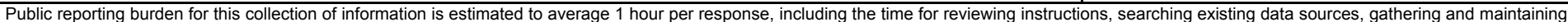

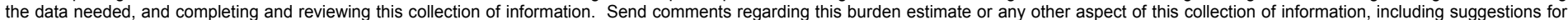

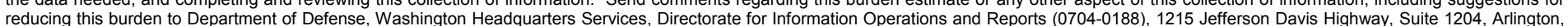

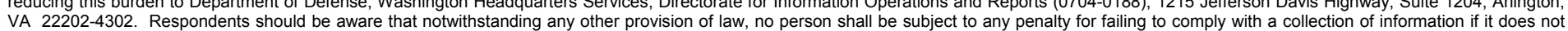
VA 22202-4302. Respondents should be aware that notwithstanding any other provision of law, no person shall be sube
display a currently valid OMB control number. PLEASE DO NOT RETURN YOUR FORM TO THE ABOVE ADDRESS.
1. REPORT DATE $(D D-M M-Y Y Y Y)$ September 2007

\section{TITLE AND SUBTITLE}

Amended Ballistic Sand Studies to Provide Low Maintenance Lead Containment at Active Small Arms Firing Range Systems
3. DATES COVERED (From - To)

5a. CONTRACT NUMBER

5b. GRANT NUMBER

5c. PROGRAM ELEMENT NUMBER

5d. PROJECT NUMBER

5e. TASK NUMBER

5f. WORK UNIT NUMBER

8. PERFORMING ORGANIZATION REPORT NUMBER

ERDC TR-07-14

\section{SPONSORING / MONITORING AGENCY NAME(S) AND ADDRESS(ES)}

U.S. Army Corps of Engineers

Washington, DC 20314-1000
10. SPONSOR/MONITOR'S ACRONYM(S)

11. SPONSOR/MONITOR'S REPORT NUMBER(S)

\section{DISTRIBUTION / AVAILABILITY STATEMENT}

Approved for public release; distribution in unlimited.

\section{SUPPLEMENTARY NOTES}

\section{ABSTRACT}

Live-fire training results in the deposition of heavy metals, such as lead and copper, into berm soils. The metals range in size from whole projectiles to microscopic dust. Surface water runoff and leachate have the potential to transport metals off-site. The Passive Reactive Berm (PRBerm) technology incorporates berm amendments with ballistic sand to immobilize soluble metals (e.g., lead) during the inevitable bullet corrosion process. Treatability studies determined that a sand to amendment ratio of 5 percent (w/w) was sufficient to contain greater than 90 percent of soluble lead within the berm material. Lysimeter studies used regulated artificial rain events to evaluate the metals concentrations, total suspended solids, dissolved organic carbon, and runoff and leachate $\mathrm{pH}$ over time for the amended and sand-only (control) berms.

The Buffer Block \#5 and SulfiTech A/T maintained average leachate lead and copper concentrations below the selected study limit of $0.150 \mathrm{mg} / \mathrm{L}$ and $0.500 \mathrm{mg} / \mathrm{L}$, respectively, maintained a pH between 6 and 9 , and maintained a dissolved organic carbon level at less than $50 \mathrm{mg} / \mathrm{L}$ for the leachate and runoff waters. Lysimeter studies indicate that amendment biological activity and $\mathrm{pH}$ affects the use of certain amendments within the PRBerm. The benefits of the PRBerm when compared to the traditional earthen berm, or a fully-contained bullet trap, include reduced metals migration, and reduced construction and operation costs.

\section{SUBJECT TERMS}

See reverse.

\section{SECURITY CLASSIFICATION OF:}

\section{a. REPORT}

UNCLASSIFIED

b. ABSTRACT
UNCLASSIFIED

c. THIS PAGE

UNCLASSIFIED 17. LIMITATION
OF ABSTRACT OF ABSTRACT 18. NUMBER
OF PAGES

83 19a. NAME OF RESPONSIBLE PERSON

19b. TELEPHONE NUMBER (include area code) 


\section{PERFORMING ORGANIZATION NAME(S) AND ADDRESS(ES) (Concluded)}

Environmental Laboratory and Geotechnical and Structures Laboratory U.S. Army Engineer Research and Development Center 3909 Halls Ferry Road, Vicksburg, MS 39180-6199;

Aberdeen Test Center, 4264 Cowan Place, Belcamp, MD 21017;

AMEC Earth and Environment, 285 Davidson Avenue, Suite 100, Somerset, NJ 08873;

EnviroComp, Inc., 3240 Hickory Woods Drive, Greenfield, IN 46140;

UFA Ventures, Inc., 403 West Riverside Drive, Carlsbad, NM 88220

\section{SUBJECT TERMS (Concluded)}

Apatite II

Ballistic sand

Best management practices (BMPs)

Buffer Block

Copper

Heavy metals

Leachate

Lead

Live-fire training

Lysimeter

Passive reactive berm

$\mathrm{pH}$

Runoff water

Small arms firing range (SAFR)

Soil amendment

Stabilization

Sulfitech 